UNIVERSIDADE DE BRASÍLIA

PROGRAMA DE PÓS-GRADUAÇÃO EM GESTÃO PÚBLICA

MESTRADO PROFISSIONAL EM GESTÃO PÚBLICA

ANÁLISE DA CONSONÂNCIA DOS PROGRAMAS NACIONAIS DE EDUCAÇÃO COM OS DÉFICITS DE INFRAESTRUTURA DAS ESCOLAS PÚBLICAS DO BRASIL: POSSIBILIDADES E DESAFIOS À DESCENTRALIZAÇÃO.

DAVID ANTONIO LUSTOSA DE OLIVEIRA

PPGP/FUP 
DAVID ANTONIO LUSTOSA DE OLIVEIRA

\section{ANÁLISE DA CONSONÂNCIA DOS PROGRAMAS NACIONAIS DE EDUCAÇÃO COM OS DÉFICITS DE INFRAESTRUTURA DAS ESCOLAS PÚBLICAS DO BRASIL: POSSIBILIDADES E DESAFIOS À DESCENTRALIZAÇÃO.}

Dissertação apresentada ao Programa de Pós Graduação em Gestão Pública - PPGP da Faculdade de Planaltina (FUP) da Universidade de Brasília (UnB) como requisito parcial à obtenção do título de Mestre em Gestão Pública.

Linha de atuação: Monitoramento e avaliação da gestão pública.

Orientadora: Prof. ${ }^{a}$ Dr ${ }^{\underline{a}}$ Maria Raquel Gomes Maia Pires 
Ficha catalográfica elaborada automaticamente, com os dados fornecidos pelo autor.

ANÁLISE DA CONSONÂNCIA DOS PROGRAMAS NACIONAIS DE EDUCAÇÃ̃O COM OS DÉFICITS DE INFRAESTRUTURA DAS ESCOLAS PÚBLICAS DO BRASIL: POSSIBILIDADES E DESAFIOS À DESCENTRALIZAÇÃO. / DAVID ANTONIO LUSTOSA DE OLIVEIRA; orientador MARIA RAQUEL GOMES MAIA PIRES. - Brasilia, 2017. $138 \mathrm{p}$.

Dissertação (Mestrado - Mestrado Profissional em Gestão Pública) -- Universidade de Brasilia, 2017.

1. QUALIDADE DA EDUCAÇÃO. 2. FINANCIAMENTO DA EDUCAÇÃ̃O. 3. DESCENTRALIZAÇÃOO. 4. INFRAESTRUTURA ESCOLAR. 5. PROGRAMA DINHEIRO DIRETO NA ESCOLA. I. GOMES MAIA PIRES, MARIA RAQUEL, orient. II. Título. 


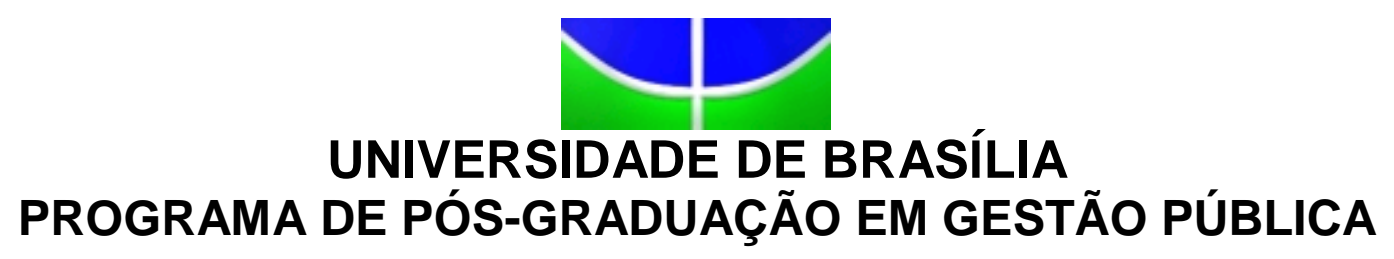

\author{
DAVID ANTONIO LUSTOSA DE OLIVEIRA
}

\title{
ANÁLISE DA CONSONÂNCIA DOS PROGRAMAS NACIONAIS DE EDUCAÇÃO COM OS DÉFICITS DE INFRAESTRUTURA DAS ESCOLAS PÚBLICAS DO BRASIL: POSSIBILIDADES E DESAFIOS À DESCENTRALIZAÇÃO.
}

\begin{abstract}
Dissertação apresentada ao Programa de Pós Graduação em Gestão Pública - PPGP da Faculdade de Planaltina (FUP) da Universidade de Brasília (UnB) como requisito parcial à obtenção do título de Mestre em Gestão Pública.
\end{abstract}

Aprovada em sua versão final pelos abaixo assinados em: 23/02/2017

Professora Doutora Maria Raquel Gomes Maia Pires

Programa de Pós-Graduação em Gestão Pública - Universidade de Brasília - Orientadora -

Professor Doutor Luiz Honorato da Silva Júnior

Programa de Pós-Graduação em Gestão Pública - Universidade de Brasília - Membro Interno -

Professora Doutora Cláudia Maffini Griboski

Departamento de Enfermagem - Universidade de Brasília

- Membro Externo - 


\section{AGRADECIMENTOS}

A Deus, fundador do universo, doador da vida, fonte de toda a sabedoria. Agradeço grandemente por todas as coisas que confluíram em prol da consecução desse propósito.

A minha querida esposa Maynnã Barros do Amaral Lustosa, amiga, companheira, parceira e incentivadora. Dádiva sem a qual não teria conseguido vencer cada desafio, obstáculo, infortúnio. Obrigado por sua paciência, generosidade, cuidado e amor. Sem dúvida, tem sua parte em cada página, cada vírgula, cada ponto, cada linha.

Aos meus pais João Batista e Maria Benedita que, sem reservas, se doaram pela minha vida, minha educação, meu sucesso. Tenho muito orgulho de nossas origens, histórias e conquistas. Mais uma vitória alcançamos... Esse título também é de vocês, muito obrigado!

Ao Fundo Nacional de Desenvolvimento da Educação (FNDE) e à Universidade de Brasília (UnB), pela rica oportunidade de adquirir novos conhecimentos e experiências, enriquecendo-nos como pessoas e profissionais. Pela oportunidade de realização de estudos no exterior, que tanto ampliou nossa visão quanto aos desafios que ainda temos pela frente.

À professora Maria Raquel, pela competência, profissionalismo, paciência e gentileza. Agradeço pela precisão e pertinência de suas orientações, que enriqueceram não apenas o estudo, como minha percepção de mundo. Sinto-me honrado de ter sido orientado por pessoa com tão elevados conhecimentos e habilidades.

À minha sogra-pastora pelo incentivo e suporte durante toda a jornada, especialmente na reta final, ajudando a cuidar de minhas duas meninas. Muito obrigado! Aos inúmeros amigos, irmãos, apoiadores, intercessores, pelo carinho, compreensão, cuidado e orações. Verdadeiramente, vocês foram muito importantes nesse processo.

Ah! Não posso esquecer de você... Obrigado Laura Melina por ter se comportado tão bem, e ter nascido somente após o dia da defesa (rsrsrs) - um dia você vai entender isso! Sua vinda trouxe muito mais emoção e ânimo na reta final desse trabalho. Papai te ama muito. 
"Existe uma coisa que uma longa existência me ensinou: toda a nossa ciência, comparada à realidade, é primitiva $e$ inocente; e, portanto, é o que temos de mais valioso."

Albert Einstein 


\section{RESUMO}

A garantia de padrão mínimo de qualidade e condições de igualdade de acesso e permanência na escola constituem princípios basilares da política educacional brasileira. A despeito de tais diretrizes, ainda se observam condições substancialmente desiguais de funcionamento dos estabelecimentos educacionais. Para mitigar esse quadro, a União deve exercer função redistributiva e supletiva, mediante assistência técnica e financeira aos entes federados. Nesse sentido, situase o Programa Dinheiro Direto na Escola (PDDE), que descentraliza recursos às escolas públicas para concorrer com a manutenção e melhoria de sua infraestrutura física e pedagógica dos estabelecimentos. O programa abrange várias ações, mais de 120 mil escolas e montantes da ordem de $R \$ 2$ bilhões por ano. Diante das desiguais condições de infraestrutura das unidades escolares do país, e dos imperativos constitucionais e legais que preconizam condições mais equânimes, levanta-se a seguinte questão: a distribuição de recursos do PDDE e de suas subações tem sido compatível com as condições de infraestrutura dos estabelecimentos de ensino, no sentido de se assegurar padrão mínimo de qualidade de infraestrutura? Após situar a problemática nas discussões em torno da qualidade da educação e descentralização de políticas públicas, procedeu-se à: a) identificação de referenciais de qualidade de infraestrutura escolar para classificação das escolas quanto às suas condições de infraestrutura; b) classificação das escolas, de acordo com seus déficits de instalações físicas, mobiliários e equipamentos, por meio de Análise Fatorial dos dados informados pelas escolas no Sistema PDDE Interativo associados a parâmetros de qualidade de infraestrutura recomendados pela literatura; e c) realização de testes de correlação de Pearson entre os valores per capita transferidos às escolas e seus respectivos déficits de instalações físicas, mobiliários e equipamentos. Além de evidenciar que as condições de infraestrutura física das escolas públicas brasileiras ainda são precárias e desiguais entre as diversas partes do país, os resultados apontam que os valores per capita destinados a essas unidades pelo PDDE e suas subações não guardam qualquer relação com os déficits de infraestrutura dos estabelecimentos educacionais.

Palavras-chave: qualidade da educação; financiamento da educação; descentralização de recursos; infraestrutura escolar; Programa Dinheiro Direto na Escola; Sistema Nacional de Educação. 


\begin{abstract}
The guarantee of minimum standard of quality and conditions of equal access and permanence in the school are basic principles of the Brazilian educational policy. Despite such directives, there are still substantially unequal conditions in the functioning of educational establishments. In order to mitigate this situation, the Union should exercise a redistributive and supplementary role, through technical and financial assistance to the federated entities. In this sense, the Direct Money in School Program (PDDE) is located, which decentralizes resources to public schools to compete with the maintenance and improvement of their physical and pedagogical infrastructure. The program covers several actions, more than 120 thousand schools and amounts of the order of $\mathrm{R} \$ 2$ billion per year. In view of the unequal infrastructure conditions of the country's educational units, and the constitutional and legal imperatives that favor more equitable conditions, the following question arises: the distribution of PDDE resources and their substations has been compatible with the infrastructure conditions of the Establish minimum standards of quality of infrastructure? After placing the problem in the discussions about the quality of education and decentralization of public policies, we proceeded to: a) identification of quality references of school infrastructure to classify schools as to their infrastructure conditions; B) classification of schools, according to their deficits of physical facilities, furniture and equipment, by means of Factor Analysis of data reported by schools in the Interactive PDDE System associated with infrastructure quality parameters recommended in the literature; And c) Pearson correlation tests were performed between the per capita values transferred to schools and their respective deficits in physical facilities, furniture and equipment. In addition to showing that the physical infrastructure conditions of the Brazilian public schools are still precarious and unequal among the different parts of the country, the results show that the per capita values assigned to these units by the PDDE and its sub-donations bear no relation to the deficits of Infrastructure of educational establishments.
\end{abstract}

Keywords: quality of education; financing of education; decentralization of resources; school infrastructure; Direct Money in School Program; National System of Education. 


\section{LISTA DE TABELAS}

Tabela 1: Instalações / dependências físicas mínimas para oferta educacional de qualidade, por nível de ensino, situadas em zonas urbanas.

Tabela 2: Equipamentos e materiais permanentes mínimos para oferta educacional de qualidade, por nível de ensino, situadas em zonas urbanas.....

Tabela 3: Instalações / dependências físicas mínimas para oferta educacional de qualidade, por nível de ensino, situadas em zonas rurais

Tabela 4: Equipamentos, mobiliários e outros materiais permanentes mínimos para oferta educacional de qualidade, por nível de ensino, situadas em zonas rurais.

Tabela 5: Descrição sintética sobre o PDDE e as ações a ele vinculadas em 2014: objetivos, públicos alvo, número de escolas contempladas e de entes federativos abrangidos, e valores transferidos em 2014

Tabela 6: Critérios de distribuição de recursos do PDDE e de suas ações agregadas para as escolas públicas, em 2014, segundo as normas.

Tabela 7: Distribuição das escolas públicas de ensino fundamental do Brasil, situadas em áreas urbanas, conforme a classificação de seus déficits de instalações físicas, mobiliários e equipamentos, realizada com base em dados do Sistema PDDE Interativo, referentes a 2014

Tabela 8: Distribuição das escolas públicas de ensino fundamental urbanas, por região geográfica, conforme a classificação de seus déficits de instalações físicas, mobiliários e equipamentos, realizada com base em dados do sistema PDDE Interativo, referentes a 2014

Tabela 9: Distribuição das escolas públicas de ensino fundamental urbanas, por vinculação administrativa, conforme a classificação de seus déficits de instalações físicas, mobiliários e equipamentos, realizada com base em dados do sistema PDDE Interativo, referentes a 2014

Tabela 10: Correlações (Pearson) entre valores per capita recebidos pelas escolas e seus respectivos déficits de instalações físicas, mobiliários e equipamentos. 
Tabela 11: Correlações (Pearson) entre valores per capita recebidos pelas escolas, para realização de despesas de custeio e capital, e seus respectivos déficits de instalações físicas, mobiliários e

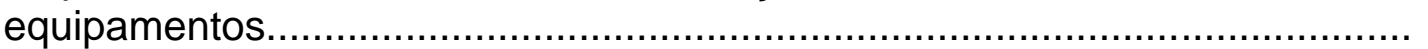

Tabela 12: Correlações (Pearson) entre valores per capita recebidos pelas escolas, repassados pelo PDDE e suas ações agregadas, e os correspondentes déficits de instalações físicas, mobiliários e equipamentos das unidades 


\section{LISTA DE GRÁFICOS}

Gráfico 1: Dotações orçamentárias para o PDDE entre 2003 e 2013.

Gráfico 2: Proporção de recursos transferidos pelo PDDE suas ações em 2014 ..

Gráfico 3: Percentual de escolas públicas de ensino fundamental, situadas em áreas urbanas, das redes municipais e estaduais, que informaram dados de infraestrutura física no sistema PDDE Interativo em 2014.

Gráfico 4: Escala para classificação das escolas quanto aos déficits de infraestrutura.

Gráfico 5: Distribuição das escolas públicas de ensino fundamental urbanas, conforme a classificação de seus déficits de instalações físicas, mobiliários e equipamentos, realizada com base em dados do sistema PDDE Interativo, referentes a 2014, entre municípios com distintos números de habitantes.

Gráfico 6: Distribuição das escolas públicas de ensino fundamental urbanas, conforme a classificação de seus déficits de instalações físicas, mobiliários e equipamentos, realizada com base em dados do sistema PDDE Interativo, referentes a 2014, entre municípios com distintos níveis de Índice de Desenvolvimento Humano Municipal (IDH-M). 


\section{LISTA DE QUADROS}

Quadro 1: Serviços e funções das escolas de ensino fundamental, de acordo com o Fundescola.

Quadro 2: Ambientes escolares mínimos para prestação dos serviços educacionais, de acordo com o Fundescola 26

Quadro 3: Mobiliários, equipamentos e materiais escolares mínimos para prestação dos serviços educacionais, de acordo com o Fundescola.

Quadro 4: Eixos, dimensões e temas abrangidos pelo sistema de informação PDDE Interativo.

Quadro 5: Variáveis e fontes de dados selecionados para realização das análises estatísticas

Quadro 6: Descrição dos fatores representativos dos déficits de infraestrutura física dos estabelecimentos públicos de ensino 


\section{LISTA DE SIGLAS E ABREVIATURAS}

$\begin{array}{ll}\text { ANA } & \text { Avaliação Nacional da Alfabetização } \\ \text { CAQi } & \text { Custo Aluno Qualidade Inicial } \\ \text { CEPAL } & \text { Comissão Econômica para a América Latina } \\ \text { CNDE } & \text { Campanha Nacional pelo Direito à Educação } \\ \text { FNDE } & \text { Fundo Nacional de Desenvolvimento da Educação } \\ \text { FUNDESCOLA } & \text { Fundo de Fortalecimento da Escola } \\ \text { GoM } & \text { Grade of Membership } \\ \text { GT } & \text { Grupo de Trabalho } \\ \text { IBGE } & \text { Instituto Brasileiro de Geografia e Estatística } \\ \text { IDEB } & \text { Índice de Desenvolvimento da Educação Básica } \\ \text { IDH } & \text { Índices de Desenvolvimento Humano } \\ \text { IDH-M } & \text { Índice de Desenvolvimento Humano Municipal } \\ \text { INEP } & \text { Instituto Nacional de Estudos e Pesquisas Educacionais Anísio } \\ & \text { Teixeira } \\ \text { IPEA } & \text { Instituto de Pesquisa Econômica Aplicada } \\ \text { LDB } & \text { Lei de Diretrizes e Bases da Educação Nacional } \\ \text { MARE } & \text { Ministério da Administração e Reforma do Estado } \\ \text { MEC } & \text { Ministério da Educação } \\ \text { MSA } & \text { Medida de Adequação da Amostra } \\ \text { OCDE } & \text { Organização para a Cooperação e Desenvolvimento Econômico } \\ \text { PAPE } & \text { Projeto de Adequação de Prédios Escolares } \\ \text { PDDE } & \text { Programa Dinheiro Direto na Escola } \\ \text { PDE } & \text { Plano de Desenvolvimento da Educação } \\ \text { PDE Escola } & \text { Plano de Desenvolvimento da Escola } \\ \text { PMDE } & \text { Programa de Manutenção e Desenvolvimento do Ensino } \\ & \text { Fundamental } \\ \text { PNE } & \text { Plano Nacional de Educação } \\ \text { PNUD } & \text { Programa das Nações Unidas para o Desenvolvimento } \\ \text { SAEB } & \text { Sistema de Avaliação da Educação Básica } \\ \text { UAB } & \text { Universidade Aberta no Brasil } \\ \text { TRI } & \text { Teoria de Resposta ao Item } \\ \text { UEx } & \text { Unidade Executora Própria } \\ \text { UNESCO } & \text { Organização das Nações Unidas para a Educação, a Ciência e } \\ & \text { a Cultura } \\ \text { UNICEF } & \text { Fundo das Nações Unidas para a Infância } \\ & \end{array}$




\section{SUMÁRIO}

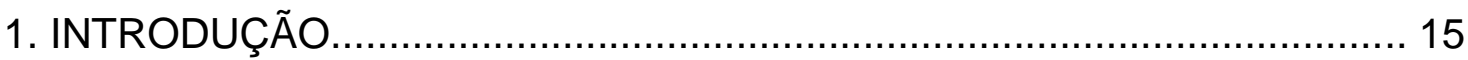

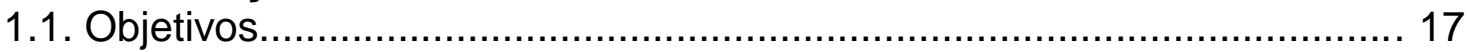

1.1.1. Objetivo Geral....................................................................... 17

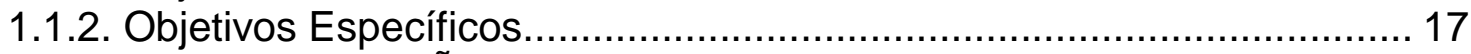

2. CONTEXTUALIZAÇÃO.............................................................. 18

2.1. A infraestrutura física das escolas e a qualidade da educação................ 18

2.2. Padrões mínimos de qualidade em infraestrutura escolar no Brasil......... 23

2.3. A desigualdade e precariedade nas condições de infraestrutura das escolas públicas no Brasil...................................................................... 33

2.4. Programa Dinheiro Direto na Escola (PDDE) como estratégia de descentralização financeira às escolas para contribuir com a manutenção e melhoria das condições de infraestrutura escolar......................................... 37

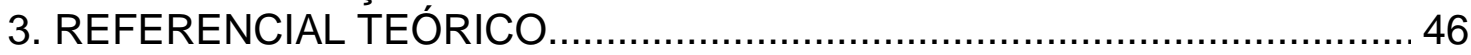

3.1. Descentralização como instrumento de atuação governamental...............46

3.2. A descentralização e o contexto político e econômico internacional......... 48

3.3. A descentralização no contexto brasileiro pós-1988.................................57

3.4. A descentralização nas políticas educacionais do Brasil..........................58

3.5. Formulação e avaliação de políticas públicas........................................ 62

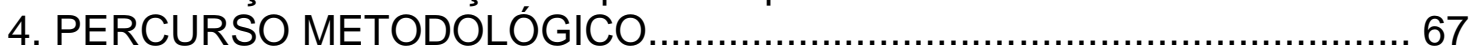

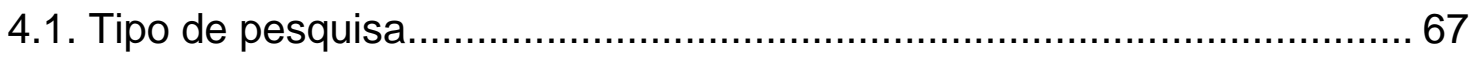

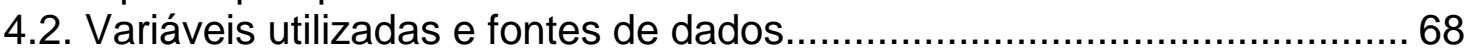

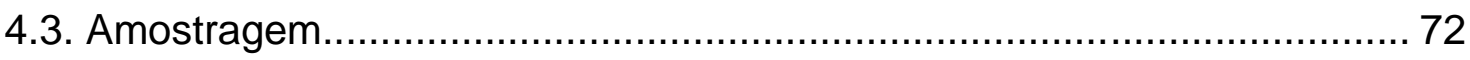

4.4. Forma de cálculo dos déficits de infraestrutura e classificação das

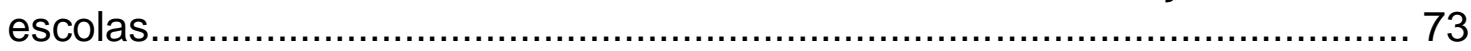

4.5. Técnica de análise dos dados ...................................................... 77

5. ANALISE DOS DADOS E RESULTADOS .................................................. 83

5.1. Estimativa de índices sintéticos, por meio de Análise Fatorial, para representar os déficits de infraestrutura física das escolas............................ 83

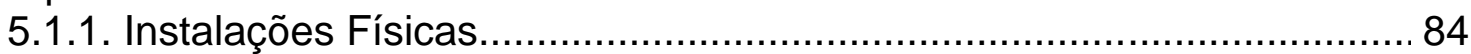

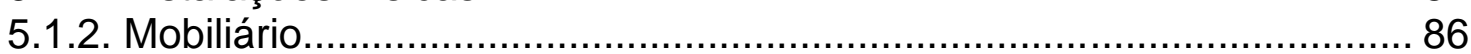

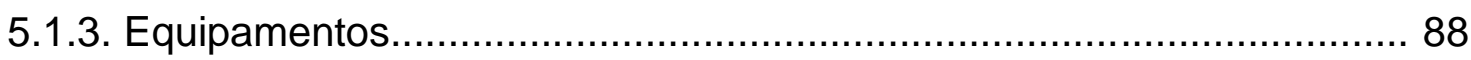

5.2. Classificação das escolas de acordo com seus déficits de

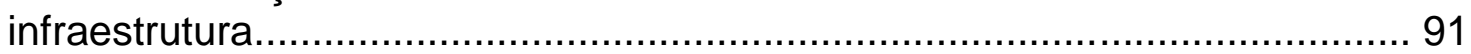

5.3. Testes de correlação entre os valores recebidos pelas escolas e seus respectivos déficits de infraestrutura........................................................ 96

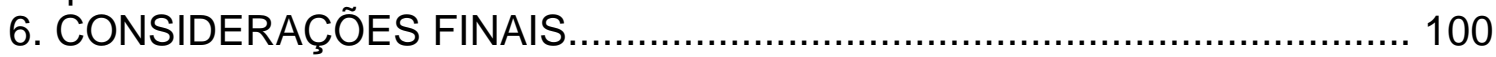

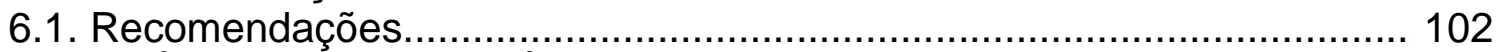

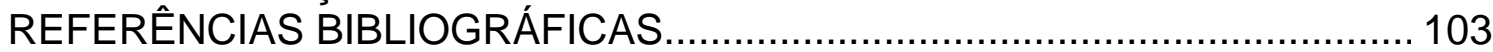

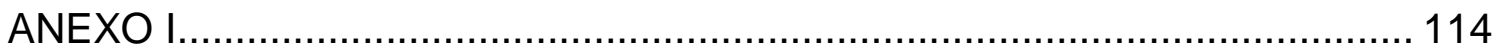

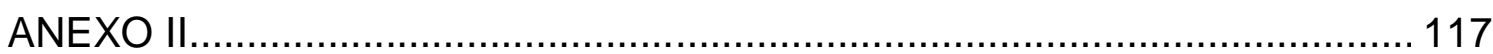

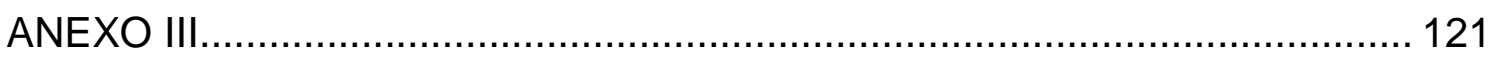

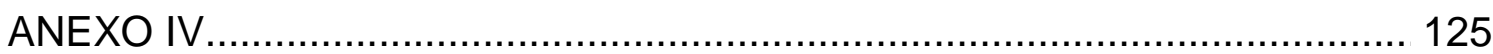

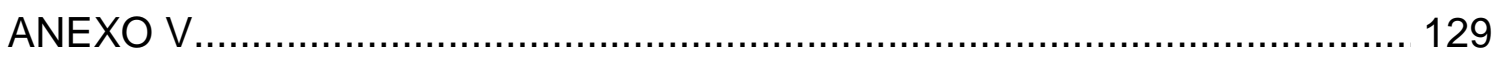

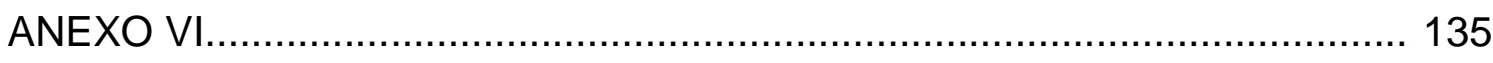




\section{INTRODUÇÃO}

A melhoria da qualidade da educação pública constitui um dos principais desafios para o Brasil. Apesar dos avanços no acesso à escolarização - como a universalização do ensino fundamental, na década de 1990 - ainda perseveram indicadores que apontam para a baixa qualidade dessa oferta educacional pública do país (FRANCO; ALVES; BONAMINO, 2007; OLIVEIRA; 2007; LIMA, 2011)

A garantia de padrão de qualidade e de condições de equidade para o acesso e a permanência na escola constituem princípios basilares da política educacional brasileira, conforme preconizado na Carta Constitucional de 1988 e Lei de Diretrizes e Bases da Educação Nacional (BRASIL, 1988; 1996). Tais fundamentos apontam para a necessidade de que a ação pública - operacionalizada por meio de programas, projetos e ações - assegure a todos estudantes não apenas o ingresso e a permanência nas escolas, mas o usufruto de ambientes escolares com condições mínimas de funcionamento, para possibilitar oferta educativa de qualidade.

A despeito de tais diretrizes, ainda se observam condições desiguais de funcionamento dos estabelecimentos educacionais brasileiros. Ao passo que algumas unidades escolares operam com satisfatória disponibilidade e qualidade de recursos humanos, infraestrutura (dependências físicas, mobiliários e equipamentos) e recursos pedagógicos, ainda subsistem muitas escolas funcionando de modo deficitário (CERQUEIRA e SAWYER, 2007; NETO ET. AL, 2013; SÁTYRO E SOARES; 2007; WAISELFISZ; 2000a; 2000b), reiterando a necessidade de investimentos na área.

A expressiva variabilidade entre as condições de funcionamento dos estabelecimentos educacionais no país - que, em países mais desenvolvidos, não variam muito de escola para escola - faz com que a consideração desses aspectos sejam indispensáveis para discussões em torno da melhoria da qualidade da educação brasileira (FRANCO ET.AL; 2007).

Para mitigar esse quadro de desigualdades, as diretrizes educacionais vigentes conferem à União o exercício de função redistributiva e supletiva, mediante assistência técnica e financeira aos Estados, ao Distrito Federal e aos Municípios, de 
forma a garantir equalização de oportunidades educacionais e padrão mínimo de qualidade do ensino a todos os cidadãos (BRASIL, 1988).

Dentre as iniciativas federais voltadas à superação das debilidades e desigualdades nas condições de funcionamento das escolas, destaque-se o Programa Dinheiro Direto na Escola (PDDE), política criada em 1995, financiada e gerida pelo Fundo Nacional de Desenvolvimento da Educação (FNDE), que descentraliza recursos às escolas públicas do país para manutenção e melhoria da infraestrutura física e pedagógica dos estabelecimentos beneficiários.

O Programa, que, em 2014, abrangeu mais oito subações, alcança mais de 120 mil estabelecimentos públicos de educação básica em todas as unidades da federação, e envolve montantes da ordem de $R \$ 2$ bilhões por ano, emerge no contexto da descentralização administrativa e financeira que se instala no Brasil pósConstituição de 1988, conferindo maiores responsabilidades às instâncias locais na execução e controle das políticas públicas (NOMA, 2011).

Nesse contexto a descentralização de políticas sociais é defendida tanto como instrumento para ampliação da democracia, como mecanismo para ampliação da eficiência do governo e eficácia das políticas públicas (ALMEIDA, 2005; KUGELMAS; SOLA, 1999). A necessidade de adotar medidas racionalizadoras e menos burocráticas, e o propósito de fortalecer a autonomia e a autogestão das escolas públicas foram algumas das principais motivações para a concepção do programa (BRASIL, 1995b).

Os desafios que se apresentam à melhoria da qualidade da educação e, especificamente, das condições de funcionamento dos estabelecimentos de ensino, ressaltam a necessidade de compreender se a distribuição de recursos efetivada pelo PDDE e por suas subações tem sido compatível com as condições de infraestrutura das unidades escolares, no sentido de se assegurar padrão mínimo de qualidade.

Em outras palavras, questiona-se se os programas federais de descentralização financeira às escolas públicas tem distribuído os recursos de maneira consoante com as condições de infraestrutura dos estabelecimentos de ensino, concorrendo para garantia de padrão mínimo de qualidade de infraestrutura. 
À luz das normas que regulamentam o PDDE e suas ações, a hipótese que se levanta é de que a distribuição de recursos propiciada por essas políticas não vem se constituindo, satisfatoriamente, instrumento para equalização das condições de infraestrutura dos estabelecimentos educacionais, com vistas a assegurar padrão mínimo de qualidade em todo o território nacional.

Além de concorrer para produção de conhecimento na área de monitoramento e avaliação de políticas públicas educacionais, esta investigação oferece subsídios para aperfeiçoamento dos programas em análise e de outros voltados à melhoria da infraestrutura das escolas, com vistas à adoção de critérios mais equitativos, que contribuam para redução das desigualdades de oportunidades educativas da população brasileira, manifestas, entre outras formas, pelos desníveis entre as condições de infraestrutura dos estabelecimentos educativos.

Ademais, o estudo corrobora a necessidade e viabilidade de avaliação contínua dos programas governamentais, a partir de informações disponíveis nos próprios repositórios de dados das instituições públicas, contribuindo para promoção de uma cultura avaliativa para a formulação de políticas públicas. Os recentes debates e esforços de educadores, gestores e da sociedade civil, no sentido de instituição e operação de um Sistema Nacional de Educação brasileiro (BRASIL, 2015c), conferem ainda mais importância à investigação, haja vista que esta oferece indícios sobre como políticas federais, estaduais e municipais podem se conjugar para melhoria das condições de funcionamento das unidades de ensino.

\subsection{Objetivos}

\subsubsection{Objetivo Geral}

Analisar se os programas federais de descentralização financeira às escolas públicas tem distribuído os recursos de maneira consoante com as condições de infraestrutura dos estabelecimentos de ensino, concorrendo para garantia de padrão mínimo de qualidade de infraestrutura.

\subsubsection{Objetivos Específicos}


1. Analisar os padrões mínimos de qualidade de infraestrutura física das escolas públicas, no contexto da política educacional brasileira.

2. Discutir teoricamente os avanços e desafios às políticas públicas de educação no Brasil, no contexto da descentralização pós-constituição de 1988.

3. Descrever os programas federais que descentralizam recursos para escolas, explicitando seus objetivos, públicos alvo, critérios de distribuição de recursos.

4. Classificar as escolas quanto a suas condições de infraestrutura, com base nos dados por essas informados no sistema PDDE Interativo e nos parâmetros mínimos de qualidade de infraestrutura recomendados pela literatura.

5. Verificar se há relação entre os valores repassados às escolas públicas, em 2014, pelos programas nacionais de descentralização financeira e os déficits de infraestrutura dos estabelecimentos escolares naquele ano.

\section{CONTEXTUALIZAÇÃO}

\subsection{A infraestrutura física das escolas e a qualidade da educação.}

A temática da qualidade da educação desperta o interesse de diversos setores da sociedade, bem como de múltiplos campos de conhecimento. Há, portanto, variedade de estudos com o propósito de identificar ou analisar fatores relacionados a essa melhoria nas condições de educação que apontam tanto para a relevância de fatores ditos "extraescolares" - aqueles que "extrapolam" os limites imediatos de atuação das unidades de ensino, abrangendo os contextos social, econômico, familiar dos alunos, por exemplo -, quanto a importância dos fatores "intraescolares" - que envolvem a organização e funcionamento das escolas, os recursos humanos e de infraestrutura que estas dispõem, entre outros aspectos que constituem, em regra, objeto de atuação das políticas públicas educacionais (DOURADO; OLIVEIRA; SANTOS, 2007; DOURADO; OLIVEIRA; 2009).

Nesse sentido, haja vista o propósito de verificar se as condições de infraestrutura das escolas públicas do Brasil, em alguma medida, vêm sendo consideradas para distribuição dos recursos federais, com vistas à oferta de padrão mínimo de condições de infraestrutura escolar a todos os brasileiros, parece-nos salutar percorrer, ainda que brevemente, as discussões sobre qualidade da 
educação, orientados pela seguinte questão: as condições de infraestrutura dos estabelecimentos de ensino afetam a qualidade educacional?

Para tanto, resgataremos estudos de Dourado, Oliveira e Santos $(2007)^{1}$, entre outros autores que discorreram sobre o tema, com ênfase no caso brasileiro, tomando como referência relevantes produções sobre o assunto.

De acordo com os autores, uma primeira consideração para abordagem do tema qualidade da educação consiste em reconhecer seu caráter polissêmico, isto é, suas múltiplas significações (DOURADO; OLIVEIRA; SANTOS, 2007). Outro pressuposto relevante é o reconhecimento de que os conceitos, concepções e representações sobre o que vem a ser educação de qualidade alteram-se no tempo e no espaço, dinâmica essa ainda mais premente na sociedade contemporânea, em face das novas demandas e exigências da sociedade (idem). Cabe ainda a consideração de que o processo educativo consiste em prática social presente em diferentes espaços e momentos dos sujeitos, não somente nas escolas, embora a educação escolar possua destacado papel nesse processo por meio de diferentes níveis, ciclos e modalidades de ensino, constituindo-se espaço institucional de produção e de disseminação, de modo sistemático, do saber historicamente produzido pela humanidade, constituindo o objeto das políticas públicas (DOURADO; OLIVEIRA; SANTOS, 2007; DOURADO; OLIVEIRA; 2009)

Segundo os autores, a definição do que vem a ser uma educação de qualidade é complexa e envolve não somente discussão sobre os insumos necessários ao funcionamento das escolas. Essa compreensão passa, antes de tudo, pela definição dos propósitos da educação, ou, nas palavras dos autores, das "expectativas e concepções acerca do que deve ser escola" (DOURADO; OLIVEIRA; SANTOS, 2007, p. 10). A partir dessas concepções "ideais" de escola, articuladas a um ideal de sociedade que se deseja construir para as próximas gerações, que faz sentido pensar a qualidade da educação:

Uma concepção de educação ou escola de qualidade que tome uma perspectiva inclusiva de sociedade, onde a exploração, a guerra, a violência sejam banidas, tem como interessante ponto de partida a definição de inclusão proposta por Santos (1997, p. 122), ou seja, a

\footnotetext{
${ }^{1}$ Revisão de literatura sobre a temática envolvendo o levantamento de estudos, avaliações e pesquisas e, ainda, a contribuição dos países membros das Cúpulas das Américas com base em instrumento de coleta de dados.
} 
de que "as pessoas e os grupos sociais têm o direito de serem iguais quando a diferença os inferioriza, e o direito a serem diferentes quando a igualdade os descaracteriza" (DOURADO; OLIVEIRA; SANTOS, 2007, p. 10).

Além dessas definições básicas relativas aos fins da educação escolar, outro elemento indispensável que se apresenta para conceitualização da qualidade da educação seria a compreensão de que condições objetivas e subjetivas devem ser observadas nas escolas para que a consecução do processo educativo atenda satisfatoriamente às expectativas da sociedade. Segundo os autores, estudos como o do Instituto Nacional de Estudos e Pesquisas Educacionais Anísio Teixeira (INEP, 2004) e da Organização das Nações Unidas para a Educação, a Ciência e a Cultura (UNESCO; 1998, 2000, 2001 e 2002) apontam que o entendimento do que vem a ser uma escola de qualidade envolve tanto discussão sobre as condições objetivas dessas unidades - categoria essa que envolve a garantia dos insumos materiais indispensáveis para manutenção e desenvolvimento da educação - quanto as condições objetivas e subjetivas da organização escolar e da avaliação de qualidade da educação.

Assim, embora a garantia dos insumos não represente condição suficiente para a qualidade da educação, a construção da "boa escola" ou da "escola eficaz" não poderia prescindir desses inputs materiais, e estes devem, necessariamente, estar articulados às:

(...) dimensões organizativas e de gestão que valorizem os sujeitos envolvidos no processo, os aspectos pedagógicos presentes no ato educativo e, ainda, contemplem as expectativas dos envolvidos com relação à aquisição dos saberes escolares significativos e às diferentes possibilidades de trajetórias profissionais futuras. (DOURADO; OLIVEIRA; SANTOS, 2007, p. 10)

Esses elementos mais subjetivos - que envolvem as características da gestão financeira, administrativa e pedagógica, os juízos de valor, a visão dos agentes escolares e da comunidade sobre o papel e as finalidades da escola - seriam, portanto, relevantes para compreensão e construção de escolas de qualidade (DOURADO; OLIVEIRA; SANTOS, 2007). Segundo os autores, uma escola eficaz seria resultado de uma construção de sujeitos engajados pedagógica, técnica e politicamente no processo educativo, o que significa dizer que não só os fatores e os insumos materiais sejam determinantes, mas que a participação ativa dos 
trabalhadores em educação, pais e alunos também são fundamentais. Em suma, para os autores, a definição da escola de qualidade haveria de considerar um conjunto de qualidades que permitem assim a definir, aspectos esses tanto de ordem objetiva quanto subjetiva.

O conjunto de aspectos tendentes a afetar o desempenho educacional podem ser, ainda, categorizados com "intraescolares" e "extraescolares". No primeiro grupo estariam abrangidas as condições de organização e funcionamento dos sistemas educativos e das próprias escolas - a adequação de suas instalações a padrões mínimos de qualidade, ambiente escolar adequado à realização de atividades de ensino, lazer, recreação, práticas desportivas e culturais, equipamentos em quantidade e qualidade adequados às atividades escolares, bibliotecas apropriadas, espaços escolares com condições de segurança, perfil docente adequado, políticas formação e valorização dos professores, adequação entre número de alunos e docentes, carga horária compatíveis com as atividades de planejamento, estudo, reuniões pedagógicas, disponibilidade de financiamento adequado para manutenção e desenvolvimento das escolas, entre outros fatores (DOURADO; OLIVEIRA; SANTOS, 2007; FRANCO et. al, 2007; DOURADO; OLIVEIRA; 2009).

O conjunto que engloba os fatores extraescolares também é apontado pela literatura como importantes para compreensão do processo educativo e, por conseguinte, da qualidade escolar. O acúmulo de capital econômico, social e cultural dos sujeitos-usuários da escola, a heterogeneidade e pluralidade sociocultural, dos problemas sociais refletidos na escola, tais como fracasso escolar, desvalorização social dos segmentos menos favorecidos, são alguns dos principais aspectos referenciados pela literatura (DOURADO; OLIVEIRA; SANTOS, 2007; FRANCO et. al, 2007; DOURADO; OLIVEIRA; 2009).

Especificamente para o caso brasileiro, a literatura aponta como especialmente relevantes para o desempenho escolar a disponibilidade de equipamentos e instalações físicas nas escolas. Diversos estudos, como de Franco, Sztajn e Ortigão (2007), Soares (2004), Lee, Franco e Albernaz (2004), e da Organização para a Cooperação e Desenvolvimento Econômico (OCDE, 2012) constatam efeito positivo entre a disponibilidade/adequação da infraestrutura física das escolas e o desempenho estudantil em testes padronizados nacionais e 
internacionais. Estudos da OCDE (2012), abrangendo 65 países situa o Brasil entre as nações com as piores condições de infraestrutura física escolar, considerando a disponibilidade e adequação de condições construtivas dos prédios escolares, sistemas de condicionamento térmico e iluminação, espaços instrucionais (salas de aula), equipamentos para laboratório de ciências, materiais didáticos, computadores para ensino, conectividade com a internet, softwares educativos e materiais para biblioteca.

Segundo Franco et.al (2007), diferentemente dos países desenvolvidos, ainda se observa grande variabilidade entre as condições de funcionamento dos estabelecimentos educacionais no Brasil, variável que precisa ser considerada para melhoria da qualidade da educação brasileira. Os autores destacam, porém, que não basta a garantia desses insumos elementares: "faz necessário que eles sejam efetivamente usados de modo coerente no âmbito das escolas" (Franco et.al, 2007, p. 282).

Na perspectiva de organismos multilaterais como Fundo das Nações Unidas para a Infância (UNICEF), Programa das Nações Unidas para o Desenvolvimento (PNUD), Comissão Econômica para a América Latina (CEPAL) e OCDE - os quais exerceram significativa influência na conformação das políticas educacionais dos países em desenvolvimento, desde a década de 80 - as discussões sobre qualidade da educação apresentam algumas similitudes (DOURADO; OLIVEIRA; SANTOS, 2007). De modo geral, para essas instituições, tanto os recursos humanos e materiais quanto os processos, currículos, são relevantes para definição do conceito de qualidade da educação. Para a Unesco $(2002,2003)$ a qualidade da educação é entendida como fator de promoção da equidade, destacando-se o impacto das experiências educativas na vida das pessoas e na contribuição para a promoção da igualdade de oportunidades. Para o Banco Mundial a melhoria da qualidade da educação efetivar-se-á por meio:

(...) da criação de sistemas nacionais de avaliação da aprendizagem e pela garantia de insumos crescentes nas escolas, tais como: livros textos, equipamentos, laboratórios e formação pedagógica. (...) Os processos de gestão também aparecem nos documentos do Banco como estratégia fundamental para pensar a melhoria da qualidade da educação. (DOURADO; OLIVEIRA; SANTOS, 2007, p. 13) 
$\mathrm{Na}$ literatura especializada, assim, em que pese o reconhecimento de que apenas a disponibilidade e adequação de condições materiais para as unidades de ensino não sejam suficientes para uma oferta educativa de qualidade, há certo consenso em torno da imprescindibilidade de dotar as escolas de condições adequadas de infraestrutura para alcance desse propósito. Caberia, agora, identificar que elementos de infraestrutura seriam necessários para uma oferta educacional de qualidade, ou seja, que instalações físicas, equipamentos, mobiliários são tidos como indispensáveis para tal propósito.

\subsection{Padrões mínimos de qualidade em infraestrutura escolar no Brasil.}

A garantia de padrão de qualidade e condições de igualdade para o acesso e a permanência na escola constituem princípios basilares da política educacional brasileira. De acordo com a Carta Constitucional de 1988, tão fundamentais como a liberdade de aprender e ensinar, o pluralismo de ideias e de concepções pedagógicas, e a gestão democrática do ensino público, são os preceitos de que todos os brasileiros devem dispor de ensino que lhes garantam certo padrão de qualidade, bem como igualdade de condições para acesso e permanência na escola (BRASIL, 1988).

A Lei de Diretrizes e Bases da Educação Nacional (Lei no 9.394, de 20 de dezembro de 1996) não apenas reitera os referidos princípios Constitucionais, como imputa ao Estado Brasileiro a obrigatoriedade de que o ensino público observe padrões mínimos de qualidade de ensino, entendidos como "a variedade e quantidade mínimas, por aluno, de insumos indispensáveis ao desenvolvimento do processo de ensino-aprendizagem (BRASIL, 1996, p. 1). A despeito das referidas determinações, não se explicitam nos referidos diplomas legais quais, precisamente, seriam essas variedades e quantidades mínimas de insumos necessários ao processo educativo que se efetiva nas escolas, especialmente no quesito infraestrutura física escolar.

No contexto normativo-legal, indicações mais específicas do que seriam esses insumos mínimos apenas vão ser observadas no primeiro Plano Nacional de Educação (PNE) pós Constituição de 1988 - Lei no 10.172, de 9 de janeiro de 2001. Além de estabelecer metas para formação/qualificação de docentes e demais profissionais dos estabelecimentos de ensino (recursos humanos), bem como definir 
percentuais mínimos de recursos financeiros a serem destinados para determinados níveis/modalidades de ensino, o plano prevê metas tanto para elaboração de padrões mínimos de infraestrutura física das escolas, quanto para sua observância pelos sistemas de ensino (BRASIL, 2001).

Embora sem minúcias, o referido normativo já sinalizava para a imprescindibilidade de determinados itens de infraestrutura para as unidades públicas de ensino - como instalações físicas para serviço de alimentação escolar, instalações sanitárias, espaços para esporte, ambientes de recreação, biblioteca reiterando a necessidade de definição de padrões mínimos nacionais de infraestrutura escolar para educação básica (BRASIL, 2001). Para o Ensino Fundamental, por exemplo, o referido Plano define como metas da educação nacional:

(...) 4. Elaborar, no prazo de um ano, padrões mínimos nacionais de infra-estrutura para o ensino fundamental, compatíveis com 0 tamanho dos estabelecimentos e com as realidades regionais, incluindo:**

a) espaço, iluminação, insolação, ventilação, água potável, rede elétrica, segurança e temperatura ambiente;

b) instalações sanitárias e para higiene;

c) espaços para esporte, recreação, biblioteca e serviço de merenda escolar;

d) adaptação dos edifícios escolares para o atendimento dos alunos portadores de necessidades especiais;

e) atualização e ampliação do acervo das bibliotecas;

f) mobiliário, equipamentos e materiais pedagógicos;

g) telefone e serviço de reprodução de textos;

h) informática e equipamento multimídia para o ensino.

5. A partir do segundo ano da vigência deste plano, somente autorizar a construção e funcionamento de escolas que atendam aos requisitos de infra-estrutura definidos. ${ }^{* \star}$

6. Assegurar que, em cinco anos, todas as escolas atendam os itens de "a" a "d" e, em dez anos, a totalidade dos itens. **

7. Estabelecer, em todos os sistemas de ensino e com o apoio da União e da comunidade escolar, programas para equipar todas as escolas, gradualmente, com os equipamentos discriminados nos itens de "e" a "h".** (BRASIL, 2001)

Como se pode observar, a conformidade com os padrões mínimos de infraestrutura deveria ser observada, inclusive, para autorização de construção de novos prédios escolar e adaptação dos existentes, de modo a assegurar que todos os estabelecimentos de educação infantil e fundamental cumprissem os requisitos mínimos (BRASIL, 2001). Apesar dessas determinações legais, segundo Dourado 
et. al. (2009) não foram observados avanços no que se refere à especificação de padrões mínimos de infraestrutura dos estabelecimentos de ensino fundamental e médio. Somente para a educação infantil foram estabelecidos parâmetros básicos oficiais de infraestrutura (BRASIL, 2006a), definindo orientações quanto aos requisitos de qualidade de infraestrutura que as unidades de ensino infantil devem observar, sem registrar, no entanto, que as variedades e quantidades de instalações, mobiliários e equipamentos seriam indispensáveis à oferta educativa com qualidade.

Assim, conforme Schneider (2010) prevalece um quadro não muito claro sobre o que, de fato, constituem esses padrões, o que acaba fazendo prevalecer uma abordagem meramente orçamentária, em detrimento do que realmente é necessário para uma educação de qualidade. Segundo a autora, em virtude da falta de definição das condições mínimas de infraestrutura a serem asseguradas às escolas, esta definição acabe sendo determinada pelos sistemas de avaliação, que ao indagarem as escolas quanto à existência de determinadas dependências físicas e equipamentos, implicitamente, supõem serem esses necessários para o funcionamento unidades de ensino (SCHNEIDER, 2010).

Nesse sentido, foi reiterada no PNE 2014-2024 - aprovado Lei no 13.005, de 25 de junho de 2014 - previsão determinando o estabelecimento de parâmetros mínimos de qualidade dos serviços da educação básica, abrangendo aspectos de infraestrutura das escolas, recursos pedagógicos, entre outros insumos indispensáveis à oferta educacional com qualidade:

(...) a União, em regime de colaboração com os entes federados subnacionais, estabelecerá, no prazo de 2 (dois) anos contados da publicação desta Lei, parâmetros mínimos de qualidade dos serviços da educação básica, a serem utilizados como referência para infraestrutura das escolas, recursos pedagógicos, entre outros insumos relevantes, bem como instrumento para adoção de medidas para a melhoria da qualidade do ensino (BRASIL, 2014e).

A despeito das citadas lacunas normativas, contribuições para o tema foram oferecidas no âmbito do Programa de Adequação de Prédios Escolares (PAPE), ação integrante do Fundo de Fortalecimento da Escola (Fundescola), iniciativa, vigente até 2007, do Ministério da Educação em parceria com o Banco Mundial, para 
melhoria das condições de funcionamento das escolas públicas de ensino fundamental das regiões Norte, Nordeste e Centro-Oeste. De acordo com Dourado et. al. (2009):

O Fundescola (...) por meio do Pape, procurou estabelecer condições de segurança, salubridade, estabilidade e funcionalidade nas escolas. (...) Para a execução do Pape e a construção de novas escolas, foram elaborados, no âmbito do Fundescola (PMFE), critérios e padrões de infraestrutura com insumos e serviços para auxiliar as secretarias de educação a observarem os padrões mínimos preconizados pelo PNE. (DOURADO ET. AL., 2009, p.113)

Os padrões mínimos de funcionamento das escolas definidos no âmbito do PAPE tomou como ponto de partida a identificação dos serviços diretos e indiretos que devem ser assegurados aos estudantes por força de disposições constitucionais, legais e/ou normativas que delimitam a política educacional brasileira (BRASIL, 2006b) (vide Quadro 1). A partir dessas determinações, foram definidos os tipos de ambientes escolares considerados indispensáveis para assegurar condições mínimas de funcionamento das escolas públicas de ensino fundamental (Quadro 2).

Quadro 1 - Serviços e funções das escolas de ensino fundamental, de acordo com o Fundescola.

\begin{tabular}{|c|c|c|}
\hline Categorias & Serviços & Funções \\
\hline \multirow{16}{*}{ 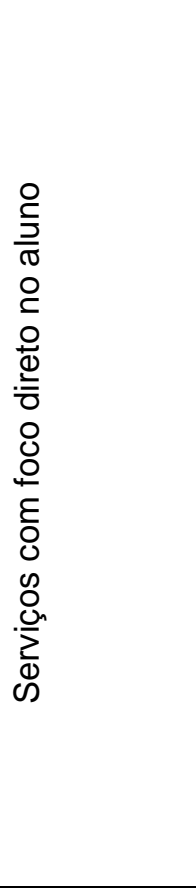 } & \multirow{2}{*}{ Docência } & Planejamento de aulas \\
\hline & & Desenvolvimento de aulas. \\
\hline & \multirow{3}{*}{$\begin{array}{l}\text { Promoção do acesso à } \\
\text { informação }\end{array}$} & Catalogação e guarda de materiais. \\
\hline & & $\begin{array}{l}\text { Disponibilização de meios e condições para veiculação } \\
\text { da informação. }\end{array}$ \\
\hline & & Realização de campanhas educativas. \\
\hline & \multirow{2}{*}{ Apoio educacional } & Assistência diária. \\
\hline & & Acompanhamento e orientação. \\
\hline & \multirow{4}{*}{ Alimentação } & Armazenamento e controle de gêneros alimentícios. \\
\hline & & Preparo ou recebimento da merenda escolar. \\
\hline & & Distribuição da merenda escolar. \\
\hline & & Higienização de equipamentos e utensílios. \\
\hline & \multirow{3}{*}{ Saúde e higiene } & Asisstência à saúde. \\
\hline & & Higiene corporal. \\
\hline & & Atendimento às necessidades fisiológicas. \\
\hline & \multirow{2}{*}{$\begin{array}{l}\text { Promoção da } \\
\text { convivência }\end{array}$} & Realização de eventos. \\
\hline & & Lazer e recreação. \\
\hline
\end{tabular}




\begin{tabular}{|c|c|c|}
\hline & & Apoio ao Grêmio Estudantil. \\
\hline \multirow{17}{*}{ 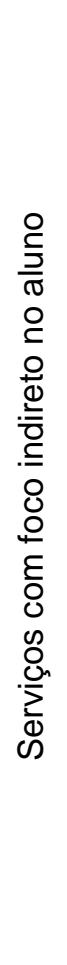 } & \multirow{2}{*}{$\begin{array}{l}\text { Suporte pedagógico à } \\
\text { docência }\end{array}$} & Coordenação pedagógica. \\
\hline & & $\begin{array}{l}\text { Disponibilização de materiais e equipamentos } \\
\text { didáticos. }\end{array}$ \\
\hline & \multirow{7}{*}{ Administração } & Planejamento e coordenação geral. \\
\hline & & Administração da vida escolar dos alunos. \\
\hline & & $\begin{array}{l}\text { Administração e desenvolvimento de recursos } \\
\text { humanos. }\end{array}$ \\
\hline & & Administração de recursos financeiros. \\
\hline & & Apoio administrativo. \\
\hline & & Manutenção de arquivos. \\
\hline & & Fornecimento de informações. \\
\hline & \multirow{4}{*}{$\begin{array}{l}\text { Manutenção, } \\
\text { conservação e } \\
\text { segurança }\end{array}$} & Limpeza. \\
\hline & & Manutenção de mobiliário e equipamentos. \\
\hline & & Manutenção predial e da área descoberta. \\
\hline & & Vigilância. \\
\hline & \multirow{4}{*}{$\begin{array}{l}\text { Integração com a } \\
\text { comunidade }\end{array}$} & Manutenção de colegiados e instituição escolares. \\
\hline & & Realização de eventos. \\
\hline & & Cessão de ambientes. \\
\hline & & Divulgação de informações. \\
\hline
\end{tabular}

Fonte: Padrões mínimos de funcionamento das escolas de ensino fundamental. 2006. Fundescola. MEC

Quadro 2 - Ambientes escolares mínimos para prestação dos serviços educacionais, de acordo com o Fundescola.

\begin{tabular}{|l|l|}
\hline \multicolumn{1}{|c|}{ Tipo } & \multicolumn{1}{c|}{ Ambiente } \\
\hline $\begin{array}{l}\text { Ambiente para atividades coletivas com, no } \\
\text { máximo, uma turma de alunos, com professores } \\
\text { e funcionários ou com pais. }\end{array}$ & Salas de aula \\
\hline $\begin{array}{l}\text { Ambiente para atividades coletivas, com várias } \\
\text { turmas de alunos, com ou sem participação } \\
\text { da comunidade local }\end{array}$ & Recreio coberto \\
\hline $\begin{array}{l}\text { Ambiente para promoção do acesso à } \\
\text { informação }\end{array}$ & $\begin{array}{l}\text { Sala de leitura, sala de TV e vídeo, sala } \\
\text { de informática, sala de multimeios }\end{array}$ \\
\hline Ambiente para atividades administrativas & $\begin{array}{l}\text { Diretora, secretaria, sala de professores, } \\
\text { sala de coordenação pedagógica }\end{array}$ \\
\hline $\begin{array}{l}\text { Ambiente para atividades de preparo de } \\
\text { alimentos/ambiente para atividades de limpeza }\end{array}$ & Cozinha, área de serviço \\
\hline Ambiente para atividades de higiene pessoal & $\begin{array}{l}\text { Sanitários dos alunos, sanitário de } \\
\text { funcionários }\end{array}$ \\
\hline
\end{tabular}

Fonte: Padrões mínimos de funcionamento das escolas de ensino fundamental. 2006. Fundescola. MEC

Além de indicar os ambientes físicos considerados indispensáveis e especificações técnicas para avaliação da qualidade desses ambientes (metragens, tipos de materiais, ergonomia, etc.), o documento aponta um conjunto de mobiliários, equipamentos e materiais didáticos considerados indispensáveis para as escolas, conforme demonstrado no Quadro 3. 
Quadro 3: Mobiliários, equipamentos e materiais escolares mínimos para prestação dos serviços educacionais, de acordo com o Fundescola.

\begin{tabular}{|c|c|c|}
\hline Item & Descrição & Quantidade \\
\hline \multirow[t]{16}{*}{$\begin{array}{l}\text { Material escolar e } \\
\text { didático }\end{array}$} & $\begin{array}{l}\text { Caderno para os alunos de } 1^{\circ} \text { a } \\
8^{\text {a }} \text { séries }\end{array}$ & 1 por aluno \\
\hline & $\begin{array}{l}\text { Lápis para os alunos de } 1^{\circ} \text { a } 8^{\text {a }} \\
\text { séries }\end{array}$ & 1 por aluno \\
\hline & $\begin{array}{l}\text { Borracha para os alunos de } 1^{\circ} \text { a } \\
8^{\underline{a}} \text { séries }\end{array}$ & 1 por aluno \\
\hline & $\begin{array}{l}\text { Livros de leitura suplementar } 1^{\underline{a}} \\
\text { a } 8^{a} \text { séries }\end{array}$ & 1 por aluno da maior turma \\
\hline & Dicionários da língua portuguesa & 1 por aluno da maior turma \\
\hline & Atlas geográfico & 1 por escola \\
\hline & Mapas geográficos & 1 por escola \\
\hline & Mapas históricos & 1 por escola \\
\hline & Globo terrestre & 1 por escola \\
\hline & $\begin{array}{l}\text { Conjunto para construções } \\
\text { geométricas }\end{array}$ & 1 por escola \\
\hline & Material dourado & 1 por escola \\
\hline & $\begin{array}{l}\text { Modelos anatômicos (torso } \\
\text { humano e arcada dentária) }\end{array}$ & 1 por escola \\
\hline & Esqueleto desmontável & 1 por escola \\
\hline & Bolas para recreacão & 1 por escola \\
\hline & $\begin{array}{l}\text { Fitas de vídeo (qualquer } \\
\text { disciplina) }\end{array}$ & 1 por escola \\
\hline & $\begin{array}{l}\text { Fitas de áudio ou CD (qualquer } \\
\text { disciplina) }\end{array}$ & 1 por escola \\
\hline \multirow{11}{*}{$\begin{array}{l}\text { Mobiliário e } \\
\text { Equipamentos para } \\
\text { Sala de Aula }\end{array}$} & Mesa para aluno & 1 por aluno \\
\hline & Cadeira aluno & 1 por aluno \\
\hline & Mesa professor & 1 por sala \\
\hline & Cadeira professor & 1 por sala \\
\hline & Armário & 1 por sala \\
\hline & Quadro de fiz & 1 por sala \\
\hline & Cadeira individual com braço & 1 por aluno \\
\hline & Estante para livros & 1 por sala \\
\hline & Quadro Branco & 1 por sala \\
\hline & Ventilador & 1 por sala \\
\hline & Condicionador de ar & 1 por sala \\
\hline \multirow{14}{*}{$\begin{array}{l}\text { Equipamentos para } \\
\text { outros ambientes } \\
\text { escolares }\end{array}$} & Máquina de escrever & Conforme necessidade da escola \\
\hline & Computador - administrativo & Conforme necessidade da escola \\
\hline & Impressora - administrativo & Conforme necessidade da escola \\
\hline & Mimeógrafo a álcool ou a tinta & Conforme necessidade da escola \\
\hline & Retoprojetor & Conforme necessidade da escola \\
\hline & Televisor & Conforme necessidade da escola \\
\hline & Videocassete ou DVD & Conforme necessidade da escola \\
\hline & Antena Parabólica & Conforme necessidade da escola \\
\hline & Aparelho de som & Conforme necessidade da escola \\
\hline & Fogão & Conforme necessidade da escola \\
\hline & Geladeira & Conforme necessidade da escola \\
\hline & Liquidificador ou batedeira & Conforme necessidade da escola \\
\hline & Bebedouro elétrico & Conforme necessidade da escola \\
\hline & Filtro & Conforme necessidade da escola \\
\hline \multirow{5}{*}{$\begin{array}{l}\text { Mobiliário para outros } \\
\text { ambientes escolares }\end{array}$} & Cadeira & Conforme necessidade da escola \\
\hline & Mesa com gaveta (escrivaninha) & Conforme necessidade da escola \\
\hline & Mesa de reunião e uso geral & Conforme necessidade da escola \\
\hline & Armário para materiais & Conforme necessidade da escola \\
\hline & Estante para livros & Conforme necessidade da escola \\
\hline
\end{tabular}


Fonte: Padrões mínimos de funcionamento das escolas de ensino fundamental. 2006. Fundescola. MEC

Apesar de não se ter explicitado os quantitativos de equipamentos e mobiliários necessários para os ambientes escolares que não sejam salas de aula, o documento do Fundescola oferece referencial relevante para avaliar as condições de infraestrutura sobre as quais operam as unidades escolares do país, com a limitação de que seu escopo se restringe ao ensino fundamental.

A indicação de itens de infraestrutura tidos como indispensáveis para o desempenho escolar satisfatório também vem sendo observada em estudos que visam estimar os custos mínimos, ou ideais, por aluno, para manutenção da oferta educacional pública com qualidade. Essas estimativas, em geral, procuram contemplar os diversos dispêndios de manutenção e desenvolvimento das unidades de ensino, incluindo gastos com docentes e demais profissionais da educação, instalações físicas, equipamentos, materiais de consumo e permanente, entre outros.

Nesse sentido, podem-se referenciar os estudos de INEP (2006) e da Campanha Nacional pelo Direito à Educação (2010). Na pesquisa do INEP (2006), abrangendo escolas públicas da educação básica de oitos estados da federação, foram consideradas como condições de infraestrutura necessárias para oferta de ensino de qualidade, além das salas de aulas, a existência de salas de leitura/biblioteca, salas de TV e vídeo, laboratórios de informática e de ciências, auditório, área livre/recreio, quadra de esporte coberta e/ou descoberta, parque infantil, piscina, copa/cozinha, refeitório, cantina, berçário, dormitório e banheiros para alunos.

As estimativas de custos por aluno, para assegurar condições de qualidade nas escolas públicas do país, promovidas pela Campanha Nacional pelo Direito à Educação, por sua vez, tem ganhado proeminência nas discussões sobre os insumos mínimos para funcionamento das unidades escolares. Esses trabalhos oferecem relevantes contribuições para definição de padrões mínimos de infraestrutura para as escolas, tendo sido considerados, inclusive, pelo Conselho Nacional de Educação como uma possível referência para construção de matriz de padrões mínimos de qualidade para a Educação Básica pública no Brasil (BRASIL, 2010a).

A proposta do Custo Aluno Qualidade Inicial (CAQi) elaborada pela Campanha com a participação de professores, pais, especialistas, estima os insumos considerados indispensáveis para oferta educacional de qualidade envolvendo infraestrutura básica, recursos pedagógicos, equipamentos, mobiliários e recursos humanos (CARREIRA; PINTO, 2010). A partir da idealização de modelos de escola para cada nível de ensino (creche, pré-escola, ensino fundamental e médio), jornada escolar (integral e parcial) e número específico de alunos, 
estimaram-se as instalações físicas, mobiliários, equipamentos e materiais didáticos considerados mínimos para funcionamento dessas unidades de ensino, bem como os custos inerentes implantação e manutenção. Segundo esses referenciais, as escolas públicas do Brasil situadas em zonas urbanas deveriam dispor, pelo menos, dos itens indicados nas Tabelas 1 e 2. Dadas as especificidades das escolas do campo, CNDE (2011), realiza estimativas específicas para escolas situadas nessas áreas, as quais são apresentadas nas Tabelas 3 e 4, para as escolas dos anos finais e iniciais do Ensino Fundamental ${ }^{2}$.

Tabela 1 - Instalações / dependências físicas mínimas para oferta educacional de qualidade, por nível de ensino, situadas em zonas urbanas.

\begin{tabular}{|c|c|c|c|c|c|}
\hline \multirow[b]{2}{*}{$\begin{array}{c}\text { Instalações / Dependências } \\
\text { físicas }\end{array}$} & \multicolumn{5}{|c|}{ Nível de Ensino } \\
\hline & $\begin{array}{c}\text { Creche } \\
(130 \\
\text { alunos, } \\
\text { turno } \\
\text { integral) }\end{array}$ & $\begin{array}{l}\text { Pré- } \\
\text { Escolar } \\
(240 \\
\text { alunos, } \\
\text { turno } \\
\text { parcial })\end{array}$ & $\begin{array}{l}\text { Fundamental } \\
\text { Anos Iniciais } \\
\text { (480 alunos, } \\
\text { turno parcial) }\end{array}$ & $\begin{array}{l}\text { Fundamental } \\
\text { Anos Finais } \\
\text { (600 alunos, } \\
\text { turno parcial) }\end{array}$ & $\begin{array}{c}\text { Médio } \\
\text { (900 } \\
\text { alunos, } \\
\text { turno } \\
\text { parcial) }\end{array}$ \\
\hline Salas de Aula & 10 & 6 & 10 & 10 & 15 \\
\hline Salas de direção/equipe & 2 & 2 & 2 & 4 & 2 \\
\hline Salas de professores & 1 & 1 & 1 & 1 & 1 \\
\hline Sala de equipe pedagógica & & & & & 2 \\
\hline $\begin{array}{l}\text { Sala do Grêmio/Convivência } \\
\text { Estudantil }\end{array}$ & & & & 1 & 1 \\
\hline Salas de leitura/biblioteca & 1 & 1 & 1 & 1 & 1 \\
\hline Bercário & 1 & & & & \\
\hline Refeitório & 1 & 1 & 1 & 1 & 1 \\
\hline Lactário & 1 & & & & \\
\hline Copa/Cozinha & 1 & 1 & 1 & 1 & 1 \\
\hline Quadra coberta & 1 & 1 & 1 & 1 & 1 \\
\hline Parque infantil & 1 & 1 & & & \\
\hline $\begin{array}{l}\text { Banheiros de } \\
\text { funcionários/professores }\end{array}$ & 2 & 2 & & & \\
\hline Banheiros de alunos & 10 & 6 & 4 & 6 & 8 \\
\hline Sala de depósito & 3 & 3 & 3 & 2 & 2 \\
\hline Salas de TV/DVD & 1 & 1 & 1 & 1 & 1 \\
\hline Laboratório de Informática & & & 1 & 1 & 1 \\
\hline Laboratório de Ciências & & & 1 & 1 & 3 \\
\hline Mecanografia & & & 1 & 1 & 1 \\
\hline
\end{tabular}

Fonte: Campanha Nacional pelo Direito à Educação. 2010.

Tabela 2 - Equipamentos e materiais permanentes mínimos para oferta educacional de qualidade, por nível de ensino, situadas em zonas urbanas.

\begin{tabular}{|c|c|c|c|c|c|}
\hline \multirow[b]{2}{*}{$\begin{array}{c}\text { Equipamentos e materiais } \\
\text { permanentes }\end{array}$} & \multicolumn{5}{|c|}{ Nível de Ensino } \\
\hline & $\begin{array}{c}\text { Creche } \\
(130 \\
\text { alunos, } \\
\text { turno } \\
\text { integral) }\end{array}$ & $\begin{array}{c}\text { Pré- } \\
\text { Escolar } \\
(240 \\
\text { alunos, } \\
\text { turno } \\
\text { parcial) }\end{array}$ & $\begin{array}{l}\text { Fundamental } \\
\text { Anos Iniciais } \\
\text { (480 alunos, } \\
\text { turno parcial) }\end{array}$ & $\begin{array}{l}\text { Fundamental } \\
\text { Anos Finais } \\
\text { (600 alunos, } \\
\text { turno parcial) }\end{array}$ & $\begin{array}{c}\text { Médio } \\
\text { (900 } \\
\text { alunos, } \\
\text { turno } \\
\text { parcial) }\end{array}$ \\
\hline \multicolumn{6}{|l|}{ Esporte e brincadeira } \\
\hline $\begin{array}{l}\text { Conjunto de brinquedos para } \\
\text { parquinho } \\
\text { Cozinha }\end{array}$ & 1 & 1 & 1 & 0 & 0 \\
\hline Freezer 305 litros & 1 & 1 & 1 & 2 & 2 \\
\hline Geladeira 270 litros & 2 & 1 & 1 & 2 & 2 \\
\hline Fogão comum lactário & 1 & & & & \\
\hline
\end{tabular}

\footnotetext{
${ }^{2}$ Não foram realizadas estimativas para os demais níveis de ensino.
} 
Coleções e materiais

bibliográficos

Enciclopédias

Dicionário Houaiss ou Aurélio

Outros dicionários

Literatura infantil

Literatura infanto-juvenil

Literatura brasileira

Literatura estrangeira

Paradidáticos

Apoio pedagógico

Equipamentos para áudio, vídeo

e foto

Retroprojetor

Tela para projeção

Televisor 20"

Suporte para TV/DVD

Aparelho de DVD

Máquina fotográfica

Aparelho com CD e rádio

Processamento de dados

Computador para sala de informática

Computador para

administração/docentes

Impressora laser

Impressora jato de tinta

Copiadora multifuncional

Fotocopiadora

Guilhotina para papel

Mobiliário em geral

Carteiras

Cadeiras

Mesa escrivaninha

Arquivo de aço com 4 gavetas

Armário de madeira com 2 portas

Mesa de leitura

Mesa de reunião sala de

professores

Armário com 2 portas para

secretaria

Mesas para refeitório

Mês para impressora

Mesa para computador

Estantes para biblioteca

Berços e colchão

Banheira com suporte

Quadro para sala

Aparelhos em geral

Bebedouro elétrico

Circulador de ar de parede

Máquina de lavar

Máquina secadora

Telefone

Aparelhos para laboratório

Kit Ciências ( $p / 40$ alunos)

Kit Biologia ( $p / 40$ alunos)

Tabela 3 - Instalações / dependências físicas mínimas para oferta educacional de qualidade, por nível de ensino, situadas em zonas rurais.

Instalações / Dependências físicas

Salas de Aula

Salas de direção/equipe

Salas de leitura/biblioteca

Sala do grêmio estudantil e de convivência dos estudantes

\section{Nível de Ensino}

Fundamental

Anos Iniciais

(60 alunos, turno parcial)
Fundamental

Anos Finais

(100 alunos, turno parcial) 
Laboratório de informática

Laboratório de Ciências

Parque infantil

Banheiros de funcionários/professores

Banheiros

Sala de depósito

Salas de TV/DVD

Espaço de circulação

$\begin{array}{ll}1 & 1 \\ 1 & 1 \\ 1 & 1 \\ & 1 \\ 1 & 1 \\ 2 & 1 \\ 2 & 2 \\ 1 & 2 \\ 1 & 1 \\ & 1\end{array}$

Fonte: Campanha Nacional pelo Direito à Educação. 2010.

Tabela 4 - Equipamentos, mobiliários e outros materiais permanentes mínimos para oferta educacional de qualidade, por nível de ensino, situadas em zonas rurais.

\begin{tabular}{|c|c|c|}
\hline \multirow[b]{2}{*}{ Equipamentos e materiais permanentes } & \multicolumn{2}{|c|}{ Nível de Ensino } \\
\hline & $\begin{array}{c}\text { Fundamental } \\
\text { Anos Iniciais } \\
\text { (60 alunos, turno } \\
\text { parcial) }\end{array}$ & $\begin{array}{c}\text { Fundamental } \\
\text { Anos Finais } \\
\text { (100 alunos, turno } \\
\text { parcial) }\end{array}$ \\
\hline $\begin{array}{l}\text { Esporte e brincadeira } \\
\text { Educação física e esportes }\end{array}$ & 24 & 25 \\
\hline
\end{tabular}

Educação física e esportes

Nível de Ensino

Equipamentos e materiais permanentes

Fundamental

Anos Iniciais

(60 alunos, turno parcial)

Fundamental

Anos Finais

(100 alunos, turno parcial)

\begin{tabular}{|c|c|c|}
\hline \\
\hline \multirow{2}{*}{\multicolumn{3}{|c|}{$\begin{array}{l}\text { Conjunto de brinquedos para parquinho } \\
\text { Cozinha }\end{array}$}} \\
\hline & & \\
\hline Freezer 305 litros & 1 & 1 \\
\hline Geladeira 270 litros & 1 & 1 \\
\hline Fogão comum lactário & 1 & 1 \\
\hline Fogão industrial & 1 & 1 \\
\hline Liquidificador industrial & 1 & 1 \\
\hline Botijão de gás 13 quilos & 2 & 2 \\
\hline Espremedor de frutas industrial & 1 & 1 \\
\hline \multicolumn{3}{|l|}{ Coleções e materiais bibliográficos } \\
\hline Enciclopédias & 1 & 1 \\
\hline Dicionário completo da língua portuguesa & 2 & 2 \\
\hline Outros dicionários & 25 & 25 \\
\hline Literatura infantil & 700 & \\
\hline Literatura infanto-juvenil & 350 & 500 \\
\hline Literatura brasileira & & 500 \\
\hline Literatura estrangeira & & 500 \\
\hline Paradidáticos & 70 & 500 \\
\hline Apoio pedagógico & 50 & 50 \\
\hline \multicolumn{3}{|l|}{ Equipamentos para áudio, vídeo e foto } \\
\hline Retroprojetor & 1 & 1 \\
\hline Tela para projeção & 1 & 1 \\
\hline Televisor $20 "$ & 3 & 2 \\
\hline Suporte para TV/DVD & 3 & 2 \\
\hline Aparelho de DVD & 3 & 2 \\
\hline Máquina fotográfica & 1 & 1 \\
\hline Aparelho com CD e rádio & 3 & 2 \\
\hline \multicolumn{3}{|l|}{ Processamento de dados } \\
\hline Computador para sala de informática & 15 & 26 \\
\hline Computador para administração/docentes & 2 & 2 \\
\hline Impressora laser & $\overline{1}$ & 1 \\
\hline Impressora jato de tinta & 1 & 1 \\
\hline Fotocopiadora & 1 & 1 \\
\hline Guilhotina para papel & 1 & 1 \\
\hline \multicolumn{3}{|l|}{ Mobiliário em geral } \\
\hline Carteiras & 50 & 42 \\
\hline Cadeiras & 56 & 75 \\
\hline Mesa escrivaninha & & 6 \\
\hline Arquivo de aço com 4 gavetas & 3 & 2 \\
\hline Armário de madeira com 2 portas & 3 & 2 \\
\hline Mesa de leitura & 5 & 7 \\
\hline Mesa de reunião sala de professores & 1 & 1 \\
\hline Armário com 2 portas para secretaria & 1 & 1 \\
\hline Mesas para refeitório & 5 & \\
\hline
\end{tabular}




\begin{tabular}{lrr}
\hline Mês para impressora & 3 & 3 \\
Mesa para computador & 17 & 25 \\
Estantes para biblioteca & 4 & 5 \\
Quadro para sala & 2 & 2 \\
Quadro para mural & 3 & 2 \\
Aparelhos em geral & & 1 \\
Bebedouro elétrico & 1 & 3 \\
Circulador de ar de parede & 3 & 1 \\
Máquina de lavar & 1 & 1 \\
Telefone & 1 & 3 \\
Lixeira & 4 & 5 \\
Aparelhos para laboratório & 4 & 3 \\
Kit Ciências (p/ 30 alunos) & 3 & \\
\hline
\end{tabular}

Fonte: Campanha Nacional pelo Direito à Educação. 2010.

Conforme se pôde observar, embora não oficiais, os referenciais propostos por CNDE (2011) são os únicos que, de fato, indicam as variedades e quantidades de instalações físicas, mobiliários e equipamentos considerados mínimos para todos os níveis de ensino, destacando, ainda, a necessidade de serem observadas as especificidades das escolas do campo.

Se a definição de padrões mínimos de qualidade de infraestrutura, por si só, ainda constitui desafio para o Estado Brasileiro, a superação da desigualdade e precariedade das condições de infraestrutura das escolas públicas do país que persistem no país apresenta-se como outro ainda maior obstáculo à concretização de uma oferta educativa de qualidade para todos os brasileiros, como se verá a seguir.

\subsection{A desigualdade e precariedade nas condições de infraestrutura das escolas públicas no Brasil.}

Ao contrário do que se observa na maioria dos países desenvolvidos, as condições de infraestrutura física das escolas brasileiras fazem diferença no desempenho dos estudantes (BROOKE e SOARES; 2008). Ao passo que nos demais países as condições materiais sobre as quais se opera o processo educativo escolar são relativamente homogêneas, a realidade brasileira ainda se defronta com prédios escolares com substanciais diferenças de infraestrutura (idem).

Os estudos e análises que se ocupam, direta ou indiretamente, em descrever ou classificar as condições de infraestrutura física dos estabelecimentos de ensino brasileiros são unânimes em assinalar a situação precária e desigual de 
funcionamento de muitas escolas do país, ainda que sob diferentes perspectivas metodológicas, fontes de dados e abrangências.

Conforme estudos de Waiselfisz (2000a; 2000b), para verificar em que medida aspectos físicos da escola influenciam o rendimento do aluno, com vistas a subsidiar o aprimoramento dos Padrões Mínimos de Funcionamento das Escolas, adotados pelo Programa Fundescola, são constatadas enormes diferenças de serviços e facilidades que existem entre as unidades escolares, inclusive dentro de uma mesma área, estado ou região. Os estudos - que abrangeram mais de 9.226 prédios escolares de 167 Municípios, de 17 Estados das Regiões Norte, Nordeste e Centro-Oeste $^{3}$-, apontam que, na totalidade dos ambientes escolares analisados, as escolas estaduais dispõem de infraestrutura melhor que as municipais. Também foram constatadas distinções expressivas entre os ambientes escolares das zonas rurais e urbanas, em favor destas últimas.

O autor também verifica elevada correlação entre o tamanho da escola e a existência de itens como quadra poliesportiva, sala de vídeo, refeitório, biblioteca, arquivo, sala de supervisão pedagógica, etc., o que, naturalmente, privilegia os alunos matriculados nas escolas maiores. Em relação à localização geográfica das unidades de ensino, também foram observadas desníveis expressivos no que se refere às condições de infraestrutura das escolas, embora todas as unidades situemse nas regiões Norte, Nordeste e Centro-Oeste:

(...) o Amapá é a que apresenta maior disponibilidade de ambientes exigidos (85,1\%), seguido pelo Mato Grosso do Sul, com 73,3\%. Nas últimas posições, temos o Pará, o Acre e o Amazonas, nos quais não se ultrapassa a metade dos ambientes exigidos. (WAISELFISZ, 2000a, p. 23)

Cerqueira e Sawyer (2007), em estudo para construção de uma tipologia para os estabelecimentos escolares brasileiros, desenvolvido com o apoio do método Grade of Membership - GoM, detectam que as escolas brasileiras podem ser categorizadas em três perfis extremos quanto às condições de infraestrutura, conforme nível de precariedade dessas condições. Segundo os autores, preocupa o fato de que a maior das escolas brasileiras adere ao perfil das mais precárias de

\footnotetext{
${ }^{3}$ Utilizando-se de bases de dados do Levantamento da Situação Escolar - LSE de 1997 e 1998, conjugados com os resultados do Sistema Nacional de Avaliação do Ensino Básico - SAEB, de 1997.
} 
infraestrutura, quadro agravado pelas disparidades regionais (CERQUEIRA E SAWYER, 2007).

Das 217.412 escolas abrangidas pelo estudo, 58,4\% foram classificadas no perfil mais crítico, composto, sobretudo, por escolas rurais municipais mal equipadas. As escolas melhores classificadas, que correspondem a pouco mais de $14,7 \%$ do universo analisado, geralmente, são de grande porte, situadas em áreas urbanas, informatizadas e bem equipadas (idem), confirmando a existência de desigualdades entre escolas pequenas $x$ grandes, rurais $x$ urbanas. A proporção de escolas consideradas mais críticas em relação à infraestrutura varia entre as Unidades da Federação, sendo maior nas regiões Norte e Nordeste e em municípios de menor porte (idem).

Num estudo comparativo das condições de infraestrutura das escolas brasileiras do ensino fundamental entre 1997 e 2005, Sátyro e Soares (2007) concluem que embora as condições materiais do ensino melhoraram muito entre 1997 e 2005, ainda prevalecem desigualdades entre as unidades escolares, especialmente em relação às situadas no campo, que, segundo os autores, funcionavam em condições inaceitáveis até então. Para eles:

(...) não resta dúvida de que a educação no campo conta com condições materiais muito inferiores à educação nas cidades, estejam ou não estas em zonas metropolitanas. (...) Na mesma linha estão as conclusões que decorrem das comparações entre redes. As redes municipais, até porque são responsáveis pela maioria das escolas rurais, contam com infra-estrutura significativamente pior que as redes estaduais e privadas. (SÁTYRO E SOARES, 2007, p.35-36)

Resultados análogos foram constatados por Neto et. al (2013) em estudo para concepção de escala de infraestrutura escolar, a partir de dados do Censo Escolar de 2011 e aplicação da Teoria da Resposta ao Item (TRI). Para os autores, as escolas brasileiras podem ser classificadas em quatro grupos, conforme o nível de "proficiência” em infraestrutura: elementar, básico, adequado e avançado, sendo que a maior parte das escolas (63,9\%) ocupam os dois patamares mais inferiores da escala. Além da situação geral insatisfatória, o estudo confirma a grande desigualdade entre as zonas urbana e rural, bem como entre as regiões Norte e Nordeste e o restante do país. Nas palavras dos autores, "o Brasil ainda está 
distante, não somente da equidade entre as escolas, mas também da garantia de um padrão mínimo de qualidade" (NETO ET. AL, 2013, p. 97).

Em outra proposta de concepção de métricas para mensurar as condições de infraestrutura escolar a partir de dados do Censo Escolar de 2007 e 2012 e da Avaliação Nacional da Alfabetização (ANA), Pieri e Santos (2014) concluem que embora tenha se detectado evolução em âmbito nacional para o período analisado, as condições de infraestrutura das unidades de ensino variam sensivelmente entre as escolas e redes. Corroborando os demais estudos, os autores verificam que as escolas municipais e rurais têm desempenho inferior para ambos os índices quando comparadas às demais redes, assim como as escolas do Norte e Nordeste também apresentam desempenho mais desfavorável que as demais regiões (PIERI E SANTOS, 2014).

Machado e Barbetta (2015), por sua vez, em recente trabalho em que propõem uma escala para mensuração do nível de aparelhamento das escolas ${ }^{4}$, elaborado com base nos dados do Saeb e uso da TRI, também constatam condições desiguais entre as unidades escolares. De acordo com os autores, cerca de $48 \%$ das escolas brasileiras podem ser enquadradas em níveis ainda elementares em termos de disponibilidade de equipamentos escolares (computadores, copiadoras, retroprojetores, televisores, etc.).

Como se pode observar, em que pese os avanços obtidos, prevalece no contexto brasileiro quadro de inadequação e desigualdades das condições materiais de oferta da educação pública no Brasil. Tal cenário ratifica a necessidade de que a ação pública - operacionalizada por meio de programas, projetos e ações - orientese no sentido de melhoria das condições das unidades de ensino, bem como de minimização progressiva desses elevados desníveis na qualidade da oferta educativa no país. Mas, os programas federais de descentralização de recursos às escolas são compatíveis com esses propósitos?

\footnotetext{
${ }^{4}$ Isto é, de disponibilidade de equipamentos escolares (computadores, copiadoras, retroprojetores, televisores, etc.)
} 


\subsection{Programa Dinheiro Direto na Escola (PDDE) como estratégia de descentralização financeira às escolas para contribuir com a manutenção e melhoria das condições de infraestrutura escolar.}

Uma das principais orientações associadas ao processo de redemocratização que se instalou no Brasil a partir da década de 80 , e que veio a eclodir da promulgação da Carta Constitucional de 1988, diz respeito à descentralização da gestão das políticas sociais.

No contexto das políticas educacionais, esse processo de conferir maiores responsabilidades às instâncias locais, na gestão e controle das políticas públicas, apresentou traços ainda mais marcantes, ampliando o protagonismo e a autonomia não somente dos municípios - níveis mais locais da federação - como também dos próprios estabelecimentos de ensino (NOMA, 2011).

Em que pesem as críticas a esse processo, sobretudo no que se refere aos reais níveis de autonomia conferida aos estabelecimentos de ensino, a ampliação da autonomia atribuída às escolas, "revela uma evolução e demonstra a importância da dimensão local" (CARVALHO, 2006). Nesse sentido, a LDB situa as escolas públicas não apenas como partícipes da organização da educação nacional como determina aos entes federativos conferir-Ihes progressivos graus de autonomia pedagógica, administrativa e de gestão financeira, reconhecendo as especificidades dos níveis territoriais mais granulares como relevantes para gestão dos sistemas de ensino, e, portanto, para formulação e implementação das políticas educacionais (BRASIL, 1996).

Nessa perspectiva descentralizadora, em 1995, foi criado pelo Fundo Nacional de Desenvolvimento da Educação (FNDE) - autarquia federal vinculada ao Ministério da Educação - o Programa de Manutenção e Desenvolvimento do Ensino Fundamental (PMDE) com a finalidade de prestar assistência financeira aos estabelecimentos públicos de Ensino Fundamental e às escolas privadas de educação especial, mantidas por entidades filantrópicas, com vistas a concorrer para manutenção do funcionamento e melhoria nas infraestruturas físicas e pedagógicas das escolas (DOURADO, 2007). 
A proposta foi justificada pela necessidade de adotar medidas racionalizadoras e menos burocráticas, de modo que os recursos chegassem com mais agilidade e diretamente às escolas, bem como pelo propósito de fortalecer a autonomia e a autogestão das escolas públicas (BRASIL, 1995b), fundando-se na ideia de que "a própria comunidade escolar é quem sabe aplicar o dinheiro para resolver os seus problemas" (FACHINI; OLIVEIRA, 2004, p. 118). Ademais, a descentralização financeira propiciada pelo Programa é apresentada como instrumento para dar cumprimento às determinações constitucionais que imputam à União a competência de atuar suplementarmente em matéria educacional, concedendo assistência financeira aos entes federativos para o desenvolvimento dos sistemas de ensino e o atendimento prioritário à escolaridade obrigatória (BRASIL, 1995b).

Os recursos transferidos pelo Programa Dinheiro Direto na Escola (PDDE) como passou a ser chamado, desde 1998, em face da Medida Provisória n. 1.784, de 14 de dezembro daquele - podem ser utilizados: a) na aquisição de material permanente e de consumo necessários ao funcionamento da escola; b) na manutenção, conservação e pequenos reparos da unidade escolar; c) na avaliação de aprendizagem; d) na implementação de projeto pedagógico; e e) no desenvolvimento de atividades; em conformidade com as prioridades definidas pelas comunidades escolares (BRASIL, 2013b).

Para efetivação dos repasses, o Programa exige que as escolas públicas com mais de cinquenta alunos constituam Unidades Executoras Próprias (UEx) entidades privadas sem fins lucrativos, representativa das escolas beneficiárias (BRASIL, 2013b). Formadas por integrantes da comunidade escolar, as UEx têm por função "administrar recursos transferidos por órgãos federais, estaduais, municipais, advindos da comunidade, de entidades privadas e provenientes da promoção de campanhas escolares, bem como fomentar atividades pedagógicas da escola" (BRASIL, 1997). Para as escolas públicas com menos de cinquenta alunos é dispensada a constituição de UEx para receberem os benefícios do programa, sendo que, nesse caso, os valores são transferidos às prefeituras/secretarias de estado de educação, que se encarregam de realizar as aquisições/contratações e distribuir os benefícios ás unidades de ensino (BRASIL, 2013b). 
Em todos os casos, as prefeituras/secretarias de estado de educação devem previamente formalizar adesão ao Programa, comprometendo-se a dar cumprimento às normas do PDDE. Tal procedimento é efetivado apenas uma vez, por meio de sistema eletrônico, não havendo necessidade de ser reiterado periodicamente (BRASIL, 2013b).

Segundo Adrião e Peroni (2007), a opção pela criação de entidades de natureza privada objetivava, declaradamente, assegurar maior flexibilidade na gestão dos recursos repassados e ampliar a participação da comunidade escolar nessa gestão. De acordo com as autoras, a sistemática inaugurada pelo PDDE constituiu indutor à institucionalização de mecanismos coletivos de gestão nas escolas e incorporação, mesmo que formal, da presença de todos os segmentos escolares nesse processo, sobretudo em regiões em que esses mecanismos eram parciais ou inexistentes. A evolução no número dessas entidades, observada entre 1995 e 2004 - que passou de 11.643 para 75.056, respectivamente -, é apresentada como indicador dessa mudança (ADRIÃO e PERONI, 2007).

Um dos principais marcos na histórica do PDDE, desde sua concepção, foi a ampliação de seu público alvo, em 2009, que passou a abranger toda a educação básica e não apenas o ensino fundamental (BRASIL, 2009a). Outro relevante marco no programa foi a destinação de recursos, desde 2006, para financiamento de ações específicas, relacionadas a outras políticas do Ministério da Educação (MEC), mas operacionalizadas sob o mesmo modelo operacional e regulamentar do PDDE (BRASIL, 2006c, 2007b, 2008b, 2009c).

Tais mudanças repercutiram substancialmente no aumento da alocação orçamentária para o Programa. Conforme demonstrado no Gráfico 1, enquanto as dotações orçamentárias destinadas ao PDDE, em 2003, correspondiam a pouco mais de $R \$ 572$ milhões; em 2013 , ultrapassaram a cifra de $R \$ 2,8$ bilhões ${ }^{5}$.

\section{Gráfico 1: Dotações orçamentárias para o PDDE entre 2003 e 2013.}

\footnotetext{
${ }^{5}$ Em valores de 2016.
} 


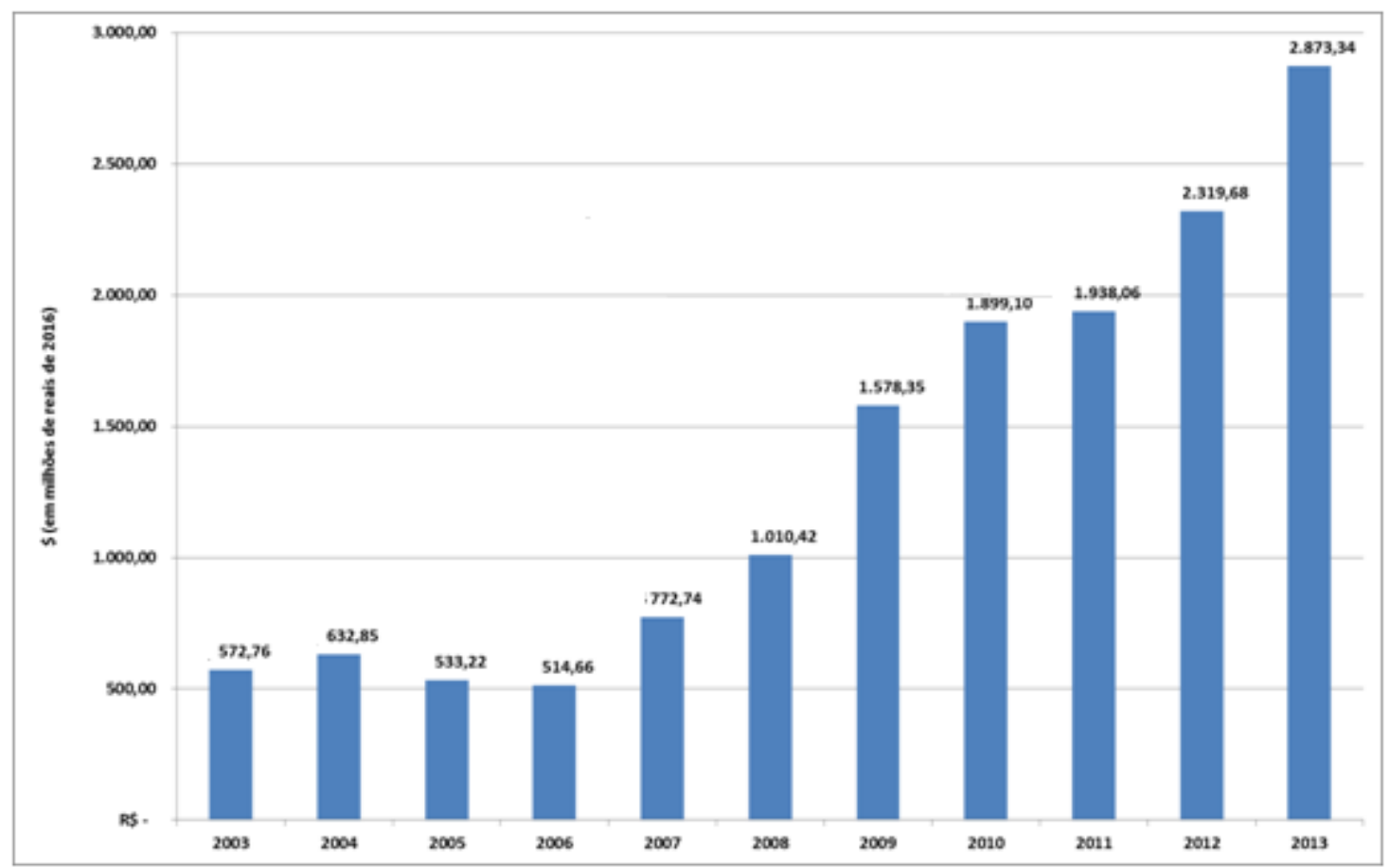

Fonte: Brasil. Fundo Nacional de Desenvolvimento da Educação. Relatório de Gestão (2013).

Nota: Em reais de 2016. Elaboração própria.

Essas transferências financeiras específicas - que passaram a ser designadas de "ações agregadas" ao PDDE - englobam objetivos e públicos alvo mais específicos, embora, segundo as normas do Programa, concorram igualmente para manutenção e melhoria da infraestrutura física dos estabelecimentos escolares (BRASIL, 2016), envolvendo desde investimentos para adequações físicas nos prédios escolares (a fim de garantir, por exemplo, abastecimento de água potável, esgotamento sanitário e acessibilidade) a repasses para ampliar a jornada escolar (idem).

Em geral, para serem contempladas com essas ações, as escolas devem ser preliminarmente selecionadas pelo Ministério da Educação, com base em critérios diversos. Após essa seleção, as unidades de ensino devem submeter ao MEC planejamento específico com a previsão das despesas a serem realizadas - as quais devem ter relação direta com os objetivos/diretrizes da ação - que, se aprovado, servirá de referência para execução dos recursos transferidos. Na Tabela 5, é apresentada breve descrição sobre o PDDE e as ações a ele vinculadas em 2014, indicando, sinteticamente, seus objetivos, públicos alvo, número de escolas contempladas, número de entes federativos abrangidos e valores totais transferidos naquele ano. 
Tabela 5: Descrição sintética sobre o PDDE e as ações a ele vinculadas em 2014: objetivos, públicos alvo, número de escolas contempladas e de entes federativos abrangidos, e valores transferidos em 2014.

\begin{tabular}{|c|c|c|c|c|c|}
\hline $\begin{array}{l}\text { Programa/ } \\
\text { ação }\end{array}$ & Objetivo & Público alvo ${ }^{6}$ & $\begin{array}{l}\text { № de } \\
\text { escolas } \\
\text { contem- } \\
\text { pladas }\end{array}$ & $\begin{array}{l}\text { № de } \\
\text { entes } \\
\text { federativos } \\
\text { abranaidos }\end{array}$ & $\begin{array}{l}\text { Valor total } \\
\text { transferido (em } \\
\text { reais) }\end{array}$ \\
\hline PDDE & $\begin{array}{l}\text { Concorrer para } \\
\text { manutenção do } \\
\text { funcionamento e } \\
\text { melhoria da } \\
\text { infraestrutura } \\
\text { física e } \\
\text { pedagógica das } \\
\text { escolas }\end{array}$ & $\begin{array}{l}\text { Escolas públicas da } \\
\text { educação básica } \\
\text { Escolas privadas de } \\
\text { educação especial }\end{array}$ & 133.360 & 5.337 & $447.051 .623,24$ \\
\hline & $\begin{array}{l}\text { Ampliação da } \\
\text { jornada escolar } \\
\text { para, no mínimo, }\end{array}$ & $\begin{array}{l}\text { Escolas públicas } \\
\text { que possuam } \\
\text { alunos matriculados } \\
\text { no Ensino }\end{array}$ & & & \\
\hline $\begin{array}{l}\text { Mais } \\
\text { Educação }\end{array}$ & $\begin{array}{l}\text { sete horas } \\
\text { diárias e } \\
\text { funcionamento } \\
\text { nos finais de } \\
\text { semana }\end{array}$ & $\begin{array}{l}\text { Fundamental } \\
\text { regular, e que } \\
\text { participem do } \\
\text { Programa Mais } \\
\text { Educação }\end{array}$ & 50.874 & 3.682 & $1.177 .477 .688,40$ \\
\hline $\begin{array}{l}\text { Atleta na } \\
\text { Escola }\end{array}$ & $\begin{array}{l}\text { Realização de } \\
\text { eventos } \\
\text { esportivos para } \\
\text { estimular o } \\
\text { esporte na } \\
\text { escola e a } \\
\text { descoberta de } \\
\text { novos talentos }\end{array}$ & $\begin{array}{l}\text { Escolas públicas } \\
\text { que tenham a partir } \\
\text { de } 10 \text { (dez) } \\
\text { estudantes na faixa } \\
\text { etária de } 12 \text { a } 17 \\
\text { anos matriculados } \\
\text { no ensino } \\
\text { fundamental e/ou } \\
\text { médio }\end{array}$ & 29.679 & 2.871 & $45.204 .879,10$ \\
\hline & $\begin{array}{l}\text { Promoção da } \\
\text { acessibilidade e } \\
\text { inclusão escolar } \\
\text { de estudantes }\end{array}$ & $\begin{array}{l}\text { Escolas públicas da } \\
\text { educação básica } \\
\text { que possuam salas } \\
\text { de recursos }\end{array}$ & & & \\
\hline $\begin{array}{l}\text { Escola } \\
\text { Acessível }\end{array}$ & $\begin{array}{l}\text { público alvo da } \\
\text { educação } \\
\text { especial em } \\
\text { classes comuns } \\
\text { do ensino regular } \\
\text { Propiciar }\end{array}$ & $\begin{array}{l}\text { multifuncionais e } \\
\text { matrícula de alunos } \\
\text { público alvo da } \\
\text { educação especial } \\
\text { em classes comuns }\end{array}$ & 9.961 & 2.225 & $111.151 .200,00$ \\
\hline $\begin{array}{l}\text { Escola do } \\
\text { Campo }\end{array}$ & $\begin{array}{l}\text { adequações e } \\
\text { benfeitorias na } \\
\text { infraestrutura } \\
\text { física das } \\
\text { escolas rurais }\end{array}$ & $\begin{array}{l}\text { Escolas públicas da } \\
\text { educação básica } \\
\text { localizadas no } \\
\text { campo }\end{array}$ & 8.130 & 1.493 & $55.073 .300,00$ \\
\hline $\begin{array}{l}\text { Ensino } \\
\text { Médio } \\
\text { Inovador }\end{array}$ & $\begin{array}{l}\text { Apoiar e } \\
\text { fortalecer o } \\
\text { desenvolvimento } \\
\text { de propostas } \\
\text { curriculares } \\
\text { inovadoras para } \\
\text { o Ensino Médio }\end{array}$ & $\begin{array}{l}\text { Escolas públicas } \\
\text { dos Estados e do } \\
\text { Distrito Federal que } \\
\text { possuam alunos } \\
\text { matriculados no } \\
\text { Ensino Médio, } \\
\text { selecionadas pelas } \\
\text { secretarias de }\end{array}$ & 7.303 & 27 & $167.204 .725,22$ \\
\hline
\end{tabular}

\footnotetext{
${ }^{6}$ Assim como o PDDE, o público alvo das ações agregadas abrange escolas públicas vinculadas às redes de ensino dos municípios, estados e do Distrito Federal. Uma distinção, porém, é que as referidas ações contemplam, exclusivamente, escolas públicas com UEx.
} 
educação

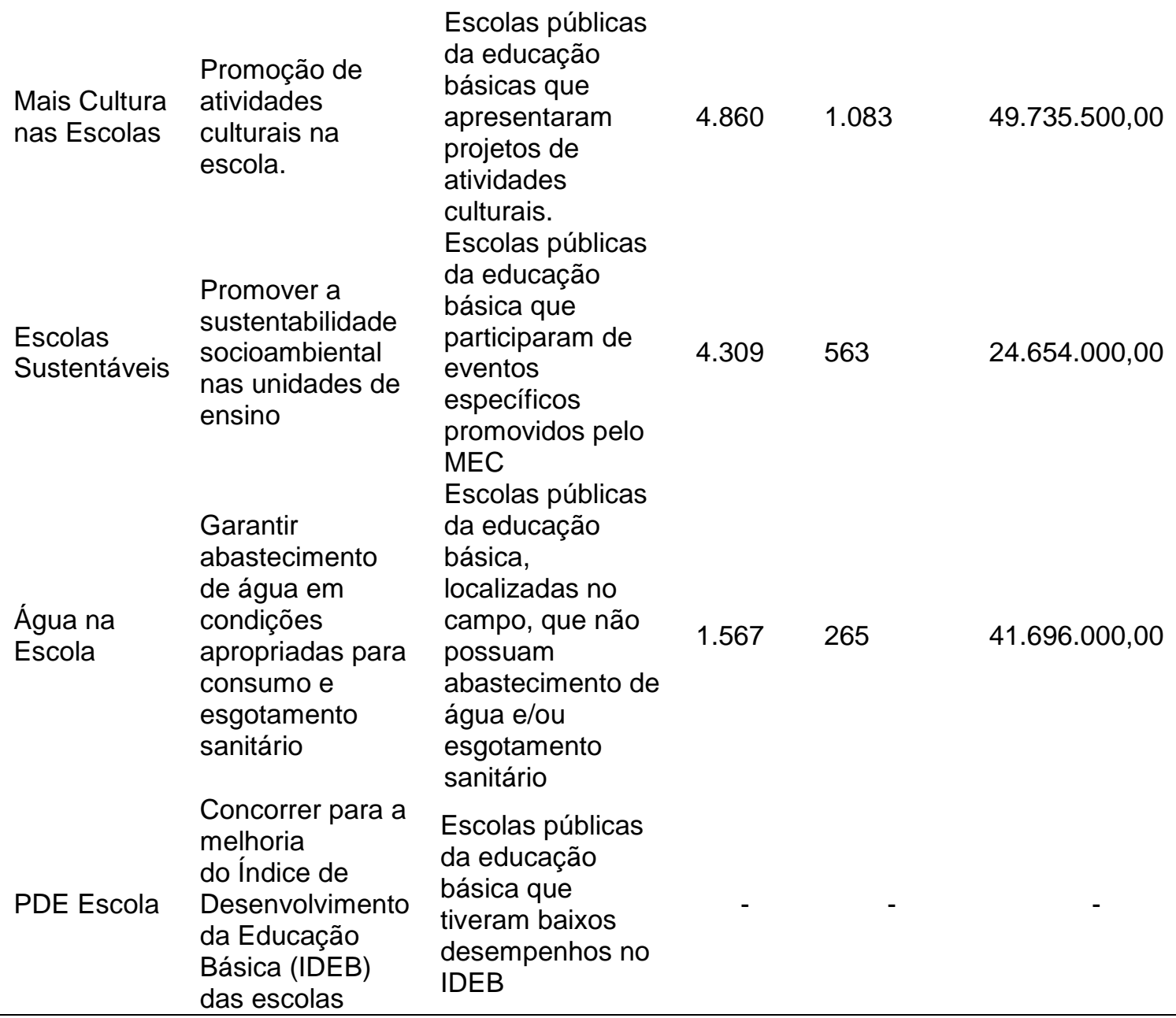

TOTAL

2.119.248.915,96

Fonte: Brasil. Fundo Nacional de Desenvolvimento da Educação. Resoluções do Conselho Deliberativo do FNDE.

Nota: Elaboração própria.

De acordo com a legislação que institui o PDDE, a distribuição dos recursos no âmbito do programa deve adotar critérios redistributivos, de modo a contemplar, prioritariamente, as escolas em condições mais desfavoráveis (BRASIL, 1995b).

A compreensão do programa como meio para redução das desigualdades sócio educacionais também figura em outros normativos emanados pelo FNDE, situando a política nos esforços de garantia de padrão mínimo de qualidade do ensino e redução das desigualdades sócio educacionais do país:

O Programa Dinheiro Direto na Escola adotará o princípio redistributivo dos recursos disponíveis de modo a garantir um padrão mínimo de qualidade do ensino e contribuir para redução das 
desigualdades sócioeducacionais entre as regiões do Pais. (BRASIL, 2008b)

A despeito da elevação orçamentária e diversificação de ações do PDDE constatada nos últimos anos, ainda se observam desafios para que a distribuição de recursos se efetive de modo redistributivo, de maneira a contribuir para mitigar as desigualdades entre as escolas e assegurar padrão mínimo de qualidade de infraestrutura a todos os estabelecimentos.

Embora, legalmente, os recursos devam a concorrer para manutenção e melhoria da infraestrutura física e pedagógica dos estabelecimentos escolares (BRASIL, 2009e), não se verifica, na estrutura normativa do PDDE e de suas ações, critérios de distribuição de recursos que levem em conta as especificidades de infraestrutura dos estabelecimentos de ensino, as quais, como sinaliza a literatura, apresentam substanciais variações entre unidades escolares.

Apesar dos conhecidos desníveis nas condições de infraestrutura das escolas do país - entre as regiões geográficas, unidades da federação, zonas de localização (urbana/rural), redes de ensino e mesmo entre escolas de uma mesma localidade -, o que se constata da análise dos marcos normativos do PDDE e de suas ações é que nem a distribuição orçamentária entre essas "rubricas" (o quanto cada programa/ação vai receber), nem a distribuição de recursos levada a efeito no âmbito de cada ação programática (o quanto cada escola vai receber, e quais escolas vão receber) se efetivam por critérios convergentes com o propósito de reduzir as referidas desigualdades.

Conforme demonstrado na Tabela 6, apenas em relação à zona de localização das escolas observam-se critérios de distribuição financeira voltados a mitigar os desníveis entre as unidades escolares. Além de serem contempladas em valores majorados pelos repasses anuais do PDDE e da ação Mais Educação (BRASIL, 2013b, 2013e), as escolas situadas em zonas rurais podem ser beneficiadas por outras duas ações vinculadas ao PDDE voltadas, exclusivamente, para esse público: as ações Água na Escola e Escola do Campo (BRASIL, 2013d; 2013c). 
No entanto, conforme demonstrado no Gráfico 2, os recursos alocados para ações voltadas, exclusivamente, às escolas rurais corresponderam, em 2014, a apenas $5 \%$ do orçamento total do programa, o que aponta para uma possível insuficiência desse mecanismo, no sentido de redução das desigualdades de insumos entre as escolas rurais e urbanas. Como indicado na Tabela 6, não se observam nas ações Atleta na Escola, Escola Acessível, Ensino Médio Inovador, Mais Cultura nas Escolas e PDE Escola quaisquer critérios que considerem as distintas condições de infraestrutura existentes entre as escolas, apontadas pela literatura, para priorização de atendimento ou cálculo dos valores a serem repassados, de modo a contribuir para redução dos mencionados déficits. No que se refere à distribuição orçamentária entre o PDDE e suas ações, sequer foram identificados nos marcos normativos vigentes que critérios são adotados para alocação dos montantes.

Tabela 6: Critérios de distribuição de recursos do PDDE e de suas ações agregadas para as escolas públicas, em 2014, segundo as normas.

\begin{tabular}{|c|c|c|}
\hline Programa/ação & $\begin{array}{l}\text { Critérios de priorização de escolas a serem } \\
\text { beneficiadas }\end{array}$ & $\begin{array}{l}\text { Critérios para cálculo dos valores } \\
\text { destinados às escolas }\end{array}$ \\
\hline PDDE & $\begin{array}{l}\text { 1) Escolas públicas da educação básica } \\
\text { 2) Se }>50 \text { alunos, deve possuir UEx }\end{array}$ & $\begin{array}{l}\text { O valor destinado a cada escola } \\
\text { depende do número de alunos, do } \\
\text { tipo de escola (pública/privada), da } \\
\text { existência ou não de UEx (no caso } \\
\text { das escolas públicas), da } \\
\text { localização (urbana/rural) e do tipo } \\
\text { de alunado (regular/especial) da } \\
\text { escola. }\end{array}$ \\
\hline Mais Educação & $\begin{array}{l}\text { 1) Escolas públicas da educação básica } \\
\text { 2) Tenham alunos matriculados no ensino } \\
\text { fundamental } \\
\text { 3.1) Se Urbanas: } \\
\text { - Escolas contempladas com PDDE/Educação } \\
\text { Integral nos anos anteriores } \\
\text { - Escolas contempladas com o PDE/Escola } \\
\text { e que possuam baixo IDEB } \\
\text { - Escolas com índices igual ou superior a 50\% } \\
\text { de estudantes participantes do Programa Bolsa } \\
\text { Família (PBF). } \\
\text { 3.2) Escolas Rurais: } \\
\text { - Municípios com } 15 \% \text { ou mais da população } \\
\text { "não alfabetizados" } \\
\text { - Municípios que apresentam } 25 \% \text { ou mais de } \\
\text { pobreza rural } \\
\text { - Municípios com } 30 \% \text { da população "rural" } \\
\text { - Municípios com assentamento de } 100 \text { famílias } \\
\text { ou mais } \\
\text { - Municípios com escolas quilombolas e } \\
\text { indígenas. }\end{array}$ & $\begin{array}{l}\text { O valor destinado a cada escola } \\
\text { depende do número de alunos } \\
\text { público alvo das atividades e da } \\
\text { localização da escola (urbana/rural) }\end{array}$ \\
\hline Atleta na Escola & $\begin{array}{l}\text { 1) Escolas públicas da educação básica } \\
\text { 2) Tenham a partir de } 10 \text { (dez) estudantes na } \\
\text { faixa etária de } 12 \text { a } 17 \text { anos matriculados no } \\
\text { ensino fundamental e/ou médio } \\
\text { 3) Pussuam UEx }\end{array}$ & $\begin{array}{l}\text { O valor destinado a cada escola } \\
\text { depende do número de alunos } \\
\text { público alvo das atividades. }\end{array}$ \\
\hline
\end{tabular}




\begin{tabular}{|c|c|c|}
\hline $\begin{array}{l}\text { Escola } \\
\text { Acessível }\end{array}$ & $\begin{array}{l}\text { 1) Escolas públicas da educação básica } \\
\text { 2) Com matrícula de alunos na educação } \\
\text { especial } \\
\text { 3) Contempladas com salas de recursos } \\
\text { multifuncionais } \\
\text { 4) Pussuam UEx }\end{array}$ & $\begin{array}{l}\text { O valor destinado a cada escola } \\
\text { depende do número de alunos. }\end{array}$ \\
\hline $\begin{array}{l}\text { Escola do } \\
\text { Campo }\end{array}$ & $\begin{array}{l}\text { 1) Escolas públicas da educação básica } \\
\text { 2) Localizadas em áreas rurais } \\
\text { 3) Pussuam UEx } \\
\text { 4) Não tenham sido beneficiadas em anos } \\
\text { anteriores } \\
\text { 5) Funcionem em edificação própria }\end{array}$ & $\begin{array}{l}\text { O valor destinado a cada escola } \\
\text { depende do número de alunos. }\end{array}$ \\
\hline $\begin{array}{l}\text { Ensino Médio } \\
\text { Inovador }\end{array}$ & $\begin{array}{l}\text { 1) Escolas públicas da educação básica } \\
\text { 2) Vinculadas às Redes de Ensino } \\
\text { Estaduais/Distrital } \\
\text { 3) Possuam UEx } \\
\text { 4) Tenham alunos matriculados no ensino médio } \\
\text { 5) Com estrutura física e quadro técnico-docente } \\
\text { que permitam a ampliação da jornada escolar } \\
\text { 6) Com capacidade de articulação com outras } \\
\text { instituições e políticas públicas, e de atebder as } \\
\text { especificidades do período noturno }{ }^{27}\end{array}$ & $\begin{array}{l}\text { O valor destinado a cada escola } \\
\text { depende do número de alunos e da } \\
\text { jornada escolar (parcial/integral). }\end{array}$ \\
\hline $\begin{array}{l}\text { Mais Cultura } \\
\text { nas Escolas }\end{array}$ & $\begin{array}{l}\text { 1) Escolas públicas da educação básica } \\
\text { 2) Tenham alunos matriculados no ensino } \\
\text { fundamental e ensino médio } \\
\text { 3) Possuam UEx } \\
\text { 4) Com maioria de alunos beneficiários do PBF } \\
\text { 5) Com propostas de ação cultural que } \\
\text { promovam maior diversidade, com mais sinergia } \\
\text { com os parceiros culturais, com maior sinergia } \\
\text { com o projeto pedagógico da escola e com maior }_{\text {consonância com as potencialidades e }} \\
\text { diversidades culturais do território. }^{28}\end{array}$ & $\begin{array}{l}\text { O valor destinado a cada escola } \\
\text { depende do número de alunos. }\end{array}$ \\
\hline $\begin{array}{l}\text { Escolas } \\
\text { Sustentáveis }\end{array}$ & $\begin{array}{l}\text { 1) Escolas públicas da educação básica } \\
\text { 2) Pussuam UEx } \\
\text { 3) Situadas em município sujeitos a emergências } \\
\text { ambientais } \\
\text { 4) Participaram da III Conferência Nacional } \\
\text { Infanto-Juvenil pelo Meio Ambiente (CNIJMA) } \\
\text { e/ou constar do cadastro das escolas que } \\
\text { realizaram a Conferência na Escola, da IV } \\
\text { CNIJMA, até } 09 \text { de maio de } 2013 \\
\text { 5) Participaram do Processo Formativo em } \\
\text { Educação Ambiental: Escolas Sustentáveis e } \\
\text { Com-Vida, oferecido pelo Ministério da } \\
\text { Educação em parceria com a Universidade } \\
\text { Aberta do Brasil }\end{array}$ & $\begin{array}{l}\text { O valor destinado a cada escola } \\
\text { depende do número de alunos. }\end{array}$ \\
\hline Água na Escola & $\begin{array}{l}\text { 1) Escolas públicas da educação básica } \\
\text { 2) Localizadas em áreas rurais } \\
\text { 3) Não possuam água potável ou esgotamento } \\
\text { sanitário } \\
\text { 4) Pussuam UEx } \\
\text { 5) Não tenham sido beneficiadas em anos } \\
\text { anteriores } \\
\text { 6) Funcionem em edificação própria }\end{array}$ & $\begin{array}{l}\text { O valor destinado a cada escola } \\
\text { depende do número de alunos. }\end{array}$ \\
\hline PDE Escola & $\begin{array}{l}\text { 1) Escolas públicas da educação básica } \\
\text { 2) Pussuam UEx } \\
\text { 3) IDEB alcançado em } 2011 \text { tenha sido igual ou } \\
\text { inferior a } 3,6 \text { nos Anos Iniciais ou } 3,2 \text { nos Anos } \\
\text { Finais } \\
\text { 4) IDEB referente a } 2011 \text {, dos anos iniciais ou } \\
\text { finais, ainda que possuam índices superiores aos } \\
\text { mencionados no inciso anterior, figure entre os } \\
5 \% \text { mais baixos resultados da rede de ensino do } \\
\text { ente federado }\end{array}$ & $\begin{array}{l}\text { O valor destinado a cada escola } \\
\text { depende do número de alunos. }\end{array}$ \\
\hline
\end{tabular}


5) Não tenham sido beneficiadas em anos

anteriores

Fonte: Brasil. Fundo Nacional de Desenvolvimento da Educação. Normas e Manuais do PDDE e de suas ações, vigentes em 2014.

Nota: Elaboração própria.

Gráfico 2: Proporção de recursos transferidos pelo PDDE suas ações em 2014.

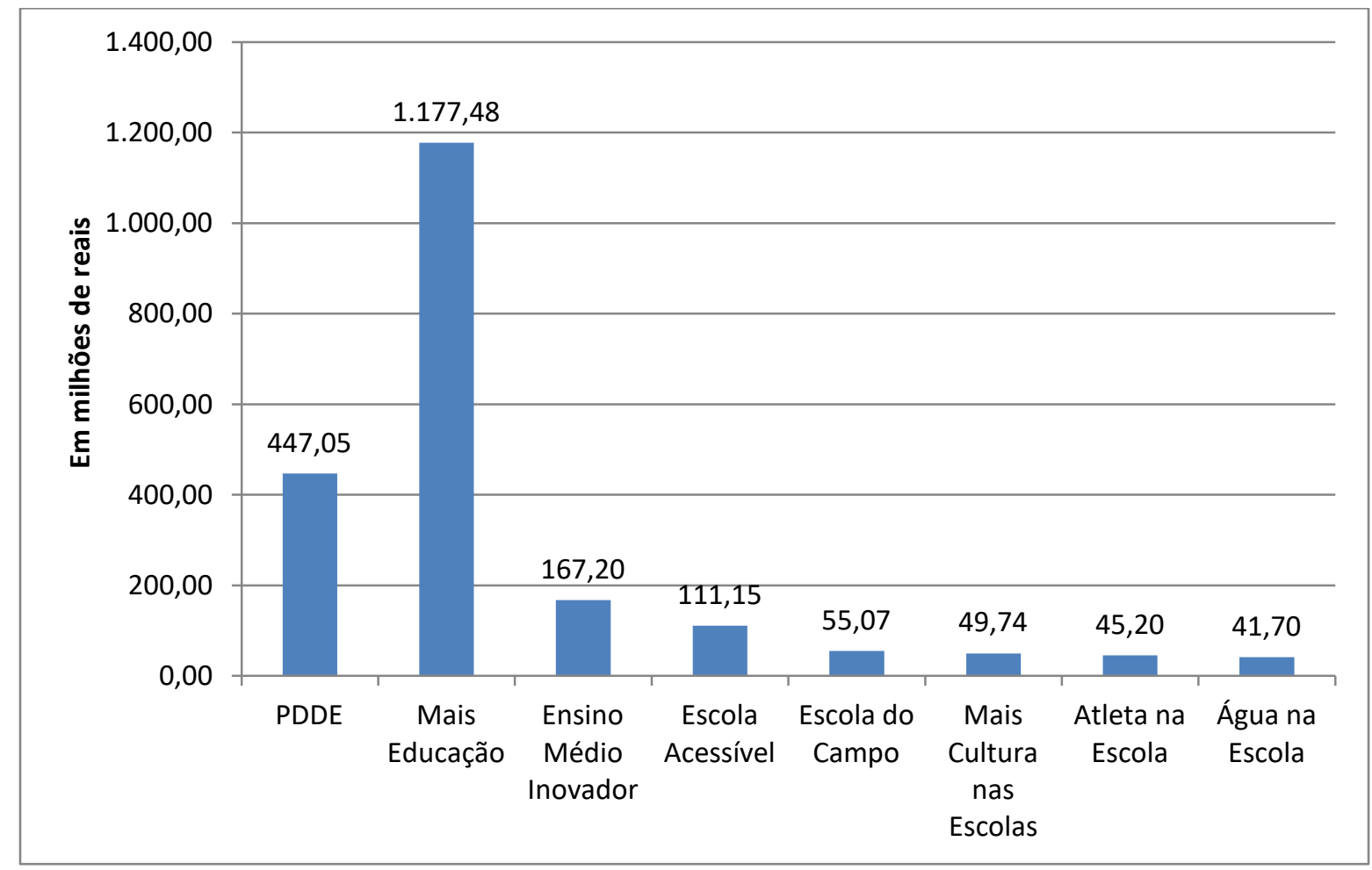

Fonte: Brasil. Fundo Nacional de Desenvolvimento da Educação. Relatório de Gestão (2014). Nota: Elaboração própria.

Diante desses apontamentos - indicativos da não adoção, ou modesta utilização, de critérios de distributivos que levem em conta as singularidades de infraestrutura dos estabelecimentos de ensino -, a hipótese que se levanta é de que a distribuição de recursos propiciada pelo PDDE e suas ações não vem se constituindo, satisfatoriamente, instrumento para equalização das condições de infraestrutura física e pedagógica dos estabelecimentos educacionais, com vistas a assegurar padrão mínimo de qualidade em todo o território nacional.

\section{REFERENCIAL TEÓRICO}

\subsection{Descentralização como instrumento de atuação governamental.}


Numa perspectiva teórica mais fundamental, a descentralização pode ser compreendida, basicamente, como distribuição de poder de decisão, ação ou execução, que se efetiva de um núcleo central para unidades locais (VIEIRA, 2012). Tal fenômeno possui caráter dinâmico, que supõem um contínuo entre dois polos extremos (embora hipotéticos), o da descentralização e o da centralização "total", de modo que seria possível diferentes graus de descentralização e, por conseguinte, possibilidade de localização dos diversos sistemas político-administrativos em pontos específicos desse contínuo, em função do nível de descentralização desses (idem).

Para o autor, o ponto específico que cada nação ocupa nesse espectro depende de seu particular contexto, que, variável no tempo, pode caracterizá-la ora extremamente centralizada num momento, ora mais descentralizada em outro, sendo que os sistemas tendem a se apresentar mistos e em movimento, combinados por elementos antagônicos, tendentes uns à centralização outros à descentralização (VIEIRA, 2012).

Motta e Pereira (1987), ao proporem forma de determinar o grau de descentralização de organizações, sugerem numa perspectiva hierárquica analisar o número de decisões tomadas na parte inferior da hierarquia, a importância das decisões tomadas nesses níveis, o número de funções cujas decisões são tomadas na parte inferior e o nível de supervisão quanto às decisões tomadas (MOTTA; PEREIRA, 1987, apud HORTALE, 1997)

Haja vista os distintos objetos da descentralização, ao mesmo tempo que esta pode constituir-se instrumento para redistribuição do poder, remanejamento de competências decisórias, no sentido de uma democratização da gestão governamental, também pode corroborar as estruturas decisórias centralizadas transferindo, basicamente, funções administrativas e executivas (LOBO, 1990).

Segundo Hortale (1997), o processo de descentralização que se efetivou nos países pode ser compreendido a partir de três diferentes padrões. O primeiro, em que o nível local passaria a atuar, sobretudo, na execução de programas e políticas públicas, o segundo, em que as políticas centrais se adaptariam às realidades 
regionais, e o último, em que o poder de decisão, e não apenas de execução, seria descentralizado.

Diante das ambiguidades decorrentes da utilização do termo descentralização para exprimir processo cujas transformações possuem substanciais diferenças de amplitude, Lobo (1990) propõem a distinção dos termos descentralização e desconcentração. O primeiro subentende alteração profunda na estrutura de poder, ampliando o número de núcleos decisórios autônomos, enquanto o segundo exprime a transferência de determinadas funções para outros núcleos, sem modificar os núcleos centralizados de poder (idem).

Revisitando estudos de Mills et. Al (1990), Hortale (1997) ressalta as diferentes formas como a descentralização, na prática, pode se manifestar. A desconcentração seria a transferência de alguma autoridade do nível central para a representação local daquela autoridade. A devolução seria a criação ou fortalecimento de níveis locais de governo independentes do governo central. A delegação seria a transferência de responsabilidades gerenciais para organizações fora da estrutura central do governo e controlada de forma indireta. A privatização, por sua vez, seria a transferência de funções governamentais para organizações do setor privado (com ou sem fins lucrativos).

Tal perspectiva, de distinguir a descentralização de outras categorias conceituais, é retomada em Vianna (1992), que define desconcentração como a dispersão físico-territorial das instituições e delegação como a execução, pelos níveis locais, de tarefas predeterminadas pelo nível central.

No que se refere aos distintos "destinatários" da descentralização, conforme sugerem Fisher (1987) e Lobo (1990) esse processo de transferência de funções/responsabilidades/poderes pode se dar, basicamente, em três direções: entre as esferas de governo, da administração direta para a indireta e do Estado para a sociedade civil (seja para o mercado, seja para organizações civis, de classe ou comunitárias, sem fins lucrativos).

\subsection{A descentralização e o contexto político e econômico internacional.}


Nos últimos anos, viram-se ressurgir, de modo vigoroso, discussões em torno da descentralização no cenário internacional. Conforme constata Dillinger (1995), dos 75 estados subdesenvolvidos cujas populações ultrapassavam cinco milhões de habitantes, em apenas doze não estavam em andamento processos de descentralização. A intensificação da redistribuição de poder político-econômico do poder central dos Estados Nacionais, rumo às unidades subnacionais de governo, pôde ser observada desde meados do século XX em nações de diversos matizes político-econômicos, desde os países de Primeiro Mundo - ante a crise do WelfareState - àqueles egressos do desmontado centralismo do "socialismo real", chegando às nações em desenvolvimento, frente ao esgotamento do modelo nacionaldesenvolvimentista (AFFONSO, 2000).

Segundo Afonso (2000), alguns dos fatores que justificaram a difusão de processos descentralizadores entre os países foram a emergência do fenômeno da "globalização" ou mundialização do capital, com o enfraquecimento do poder regulatório dos Estados nacionais; a emergência dos regional states - espaços econômicos que se conectam com a economia internacionalizada, "acima" do controle do Estado-nação; e a reascensão do ideário liberal, advogando pela redução do papel do Estado na economia e assumindo o paradigma da descentralização como caminho para elevação da eficiência no setor público.

As sucessivas crises econômicas que se abateram sobre o mundo capitalista a partir de 1970, passados trinta anos de relativa prosperidade nos países centrais após a Segunda Guerra Mundial, e o consequente movimento do capital em busca de sua reprodução, acumulação e expansão, delineiam o contexto histórico em que se deu o esgotamento dos arranjos políticos e econômicos vigentes (NOMA, 2011). Até então, o Estado, fortalecido pela inspiração keynesiana, detinha papel proeminente de regulação social, política e econômica, seja em sua manifestação "Desenvolvimentista", nos países subdesenvolvidos; seja em sua face de "Bem Estar Social”, nos países centrais da América do Norte e da Europa.

Com as crises cíclicas do capitalismo, ganharam força argumentos que creditavam à configuração intervencionista do Estado e a sua insatisfatória capacidade administrativa a responsabilidade pelos colapsos - agravados, no caso dos Welfare State, aos custos econômicos da ampla rede de proteção social que se 
criara (NOMA, 2011). O Estado, que outrora figurava como fórmula salvadora para promoção de projetos de desenvolvimento econômico sobre bases keynesianas; na perspectiva neoliberal, passou a ser encarado como parte principal do problema, motivo pelo qual veio predominar a ideia de necessidade de redefinição de seus papéis, de reforma em seu aparelho, assumindo como modelo de excelência a "forma de ser" do mercado (idem). Com o esgotamento dos modelos anteriores, ocorre reconfiguração e nova dinâmica da produção e acumulação capitalista, assim como do sistema ideológico e político que as suportam, cujos contornos se evidenciaram com o advento do neoliberalismo (idem).

O enxugamento da estrutura do Estado, a descentralização, a adoção da administração pública gerencial - flexível, adaptável e orientada às necessidades dos "cidadãos-clientes" - foram algumas das principais diretrizes dos processos reformadores neoliberais (NOMA, 2011). Essas reformas, cujos expoentes se deram na Inglaterra e Estados Unidos, em 1979 e 1980, respectivamente, nos governos de Margareth Thatcher e Ronald Reagan, vieram a repercutir em reformas similares em diversos países, como foi o caso da Suécia, Nova Zelândia, Austrália, México, Argentina e Uruguai, na década de 1980, e do Brasil, na década seguinte (BRESSER PEREIRA, 1999).

Na América Latina, a descentralização esteve associada aos processos de redemocratização que sucederam a partir dos anos 1980, à crise fiscal dos governos centralizados e a problemas de governabilidade (AFFONSO, 2000).

Sob a perspectiva progressista, a descentralização era encarada como condição necessária para viabilização do ideário democrático, à medida que a elevação do poder dos níveis mais locais ampliaria a visibilidade e controle dos sistemas decisórios, favorecendo a participação cidadã sobre as estruturas e processos de decisão (TOBAR, 1991). Já sob a ótica neoliberal, as transferências de responsabilidades atenderiam às exigências de "aplacamento" da crise fiscal, mediante diminuição do Estado Central, introdução de regras de "comportamento privado" no setor público, possibilitando concorrência entre as esferas descentralizadas, tendo por fim o aumento da eficiência na prestação dos serviços, em que o maior beneficiário seria o "cidadão-cliente" (AFFONSO, 2000). Esses 
multifacetados propósitos em torno da descentralização, ressaltando seu sentido de “meio", são sintetizados por Tobar (1991):

[...] o conceito foi esboçado como ferramenta para expansão e intensificação da democracia, e também como mecanismo de controle e dominação. Da mesma forma, há definições que são compatíveis com a estatização dos serviços e outras centradas na transferência dos mesmos ao setor privado. Na sua aplicação podese perseguir tanto a equidade como manter as diferenças no acesso aos serviços que existem até o presente. (TOBAR, 1991, p. 4).

Conforme Fiori (1995), independentemente do espectro político-ideológico, havia certo consenso em torno da necessidade de transferência de poderes e responsabilidades: a) entre um mesmo nível de governo (da administração direta para indireta), b) entre níveis de governo (do poder central para as esferas subnacionais), c) para organizações da sociedade civil, e, finalmente, d) para empresas privadas.

Em que pese a recorrente utilização do termo em contraposição à extrema centralização, Vieira (2012) ressalta o atributo dinâmico associado ao conceito de descentralização, isto é, de existência de diferentes graus de descentralização e a possibilidade de se situarem os vários sistemas políticos-administrativos em pontos específicos desse espectro. Nesse sentido, a descentralização pode ser enfatizada, como sinaliza Rodden (2005), sobre os vieses de transferência de autoridade fiscalque enfoca a distribuição de despesas e receitas entre os níveis de governo -; política - assegurando-se a possibilidade de que, pelo sufrágio universal, os cidadãos escolham seus dirigentes locais -; e de políticas públicas - conferindo poderes para os governos locais e regionais decidirem sobre áreas específicas, como educação, saúde e infraestrutura.

As experiências concretas de descentralização, no entanto, apontam diversas limitações relativas a esse processo, como falta de capacidade técnica e/ou autonomia financeira das unidades subnacionais para assumir novos encargos; inadequação no controle e acompanhamento das políticas sociais descentralizadas; dificuldade de estruturar e manter coalizões políticas em prol da descentralização; incongruência entre descentralização e as políticas de estabilização macroeconômica; e dificuldades de articular descentralização com as políticas redistributivas (AFFONSO, 2000; RODDEN, 2005; TOBAR, 1991). 


\subsection{A descentralização no contexto brasileiro pós-1988.}

Durante toda a história do federalismo brasileiro verifica-se alternância de períodos de centralização e descentralização. Habitualmente, a centralização é identificada como autoritarismo e a descentralização como avanços democráticos (KUGELMAS E SOLA; 1999).

Apesar do movimento relativamente pendular da forma de organização do Estado Brasileiro, o que se verifica é que a alternância entre os regimes não anula completamente os mecanismos institucionais anteriores, mas apenas modifica o padrão de relacionamento entre as esferas, numa dinâmica de "aperto/afrouxamento de controles políticos e fiscais" (KUGELMAS; SOLA, 1999, p. 64). Para Lobo (1999), na história do país predominam arranjos políticos-institucionais centralizadores, com raros períodos de afrouxamento do poder decisório no âmbito do Estado, fruto da herança do amplo período colonial.

Nesse sentido, como destacam os autores, a Carta Constitucional de 1988 que inaugura a recente "fase" democrática no país manifesta-se como forte reação à "fase" centralizadora que a antecede, caracterizada pela ampliação da concentração fiscal na União, dependência econômica dos Estados menos desenvolvidos e limitação na autonomia administrativa dos governos locais (KUGELMAS E SOLA, 1999). Segundo Afonso e Lobo (1996), a lógica de aumentar recursos e poderes dos governos locais proveio da reação dos governos subnacionais contra a excessiva concentração de poder do regime anterior. O insatisfatório resultado conseguido com a centralização, com consequências perversas para a maioria da população reforça a tese da necessidade de descentralização dos serviços públicos (LOBO, 1990).

Lobo (1990) destaca que, nessa fase, a tendência histórica à centralização esteve em desequilíbrio, haja vista que, embora os governos subnacionais estivessem mais sensíveis às consequências danosas do excesso de centralização, prevalecia modelo de expressiva subordinação política, técnica e financeira ao governo central.

A reação ao quadro excessivamente centralizador do regime militar, faz com que o padrão de organização federativa que emerge da Constituição Federal de 
1988 seja considerado um dos mais descentralizados entre os países em desenvolvimento, conferindo maior autonomia fiscal e administrativa aos Estados e, inclusive, reconhecendo os municípios como entes da federação (KUGELMAS E SOLA, 1999). Nas palavras de Viana e Machado (2009):

(...) a associação entre democracia e descentralização de políticas ganha força e se traduz na Constituição Federal de 1988, que redesenha a estrutura de Estado em uma lógica de federação descentralizada, com ênfase no papel dos municípios. (VIANA $E$ MACHADO, 2009).

A descentralização fiscal que se efetiva, por exemplo, pode ser demonstrada ao verificar a redução na participação federal na receita disponível entre 1989 e 1996, passando de $61,1 \%$ para $56,4 \%$ no período (KUGELMAS; SOLA, 1999).

Essa elevação nos recursos para os níveis locais, porém não foi acompanhada da correspondente transferência de encargos, prevalecendo grande número de competências conjuntas dos três níveis, sem clara definição das respectivas esferas (KUGELMAS E SOLA, 1999; LOBO, 1990). Segundo os autores, este constituiu um dos principais problemas no equacionamento da descentralização das políticas sociais. Ao descrever o cenário que se apresenta no pós-1988, Lobo (1990) considera-o como:

(...) um sistema de redes paralelas ou superpostas, cujo resultado mais visível é a indefinição de competências, a dispersão de esforços e recursos, a não possibilidade de responsabilização de entes públicos pela inexistência ou inadequação da prestação de serviços. (LOBO, 1990, p. 7)

A descentralização entre as esferas governamentais, segundo Lobo (1990), não poderia se restringir ao enfoque financeiro, devendo se desmembrar em, pelo menos, duas dimensões, a financeira - via redistribuição de receitas públicas - e a político/institucional - mediante novos arranjos no sistema de competências governamentais (LOBO, 1990). No caso brasileiro, porém, segundo Arretche (1997), esta segunda dimensão foi comprometida, visto que não havia uma estratégia ou um programa nacional de descentralização orientado a partir de um centro, com a redistribuição de funções e competências entre os entes federados, que implicasse no rearranjo das estruturas político-institucionais. 
Corrobora esse entendimento, conclusões de Almeida (2005), de que a descentralização que materializou no Brasil na década de 1990, longe de ser uma política coerente, constituiu processo longo e espasmódico, cujo progresso dependeu mais da disposição de ministérios e agências federais de abrir mão de doses de poder decisório e de recursos, de sua capacidade de negociação e inovação institucional - propiciando incentivos adequados para estimular os municípios a assumirem responsabilidades - e da experiência administrativa prévia nos governos locais. Nas palavras da autora:

(...) ainda que a tendência geral fosse na direção do aumento das responsabilidades dos governos locais, nos marcos do federalismo cooperativo a descentralização significou coisas diferentes e ocorreu em ritmos diferentes, de acordo com o desenho específico de cada política. (ALMEIDA, 2005, p. 37)

Em que pese o modelo federativo cooperativo apontado pela Constituição, caracterizado pela existência de funções compartilhadas entre as esferas de governo para diversas áreas sociais (como educação, saúde, cultura, assistência social, educação), não houve determinação Constitucional quanto às formas de cooperação entre níveis de governo, conforme destaca Almeida (2005). Kugelmas e Sola (1999) reforçam que "o que se observa com nitidez é a ausência de mecanismos cooperativos mais eficazes, quer entre União e estados, quer nas relações entre estes" (KUGELMAS E SOLA, 1999, p. 73).

Diante disso, revisitando estudos de Almeida (2007), Viana e Machado (2009) ressaltam que, embora a retórica constante da nova Constituição se oriente num sentido da descentralização, o modelo de Estado que se configura nos anos seguintes baseia-se num centro nacional forte, com capacidade decisória e amplos recursos de regulação sobre as instâncias subnacionais e os mercados.

O revés pendular em direção ao (re) fortalecimento do "centro", conforme Kugelmas e Sola (1999), em muito se favoreceu dos impasses macroeconômicos relacionados à crescente dívida externa e interna, hiperinflação, desequilíbrio fiscal e a crise política que se estabelecem já no início da década de 1990, com a saída do presidente Collor de Mello. A instituição do Fundo Social de Emergência (FSE), limitando o volume de transferências vinculadas a estados e municípios, e 
encaminhando para o lançamento do Plano Real, foi um dos primeiros movimentos nesse sentido. (idem).

O período que se sucede com a eleição de Fernando Henrique Cardoso, seria marcado pelas tentativas de reenquadramento dos entes subnacionais pelo poder central, justificadas pela busca por soluções para o desequilíbrio fiscal (KUGELMAS E SOLA, 1999). Para Almeida (2005), a capacidade real de os governos subnacionais exercerem plenamente sua autonomia sofreu substanciais restrições na década de 90, motivada por basicamente dois movimentos do governo federal.

O primeiro, motivado pela forma como se deu o enfrentamento das restrições macroeconômicas associadas à estabilização da moeda e ajustamento da economia, e o segundo consequência dos esforços para assegurar recursos à consecução dos programas sociais (ALMEIDA, 2005). O Plano Real, a negociação das dívidas estaduais e a Lei de Responsabilidade Fiscal (LRF), por exemplo, foram algumas das medidas decorrentes do desenfreio macroeconômico que deram força à imposição de medidas restritivas pelo governo federal, reduzindo a autonomia de gasto dos entes subnacionais. O segundo movimento, a vinculação de receitas e de transferências intergovernamentais para gastos sociais específicos, justificada pela necessidade de eficiência das políticas sociais, foi outra medida tendente a reduzir a autonomia real dos entes subnacionais e, ao mesmo tempo, induzir os níveis locais a assumirem responsabilidades na consecução dos fins sociais (idem).

Segundo Lobo (1990), ao sinalizar alguns entraves à consecução da descentralização no país, ressalta que o primeiro deles decorreria justamente da dimensão política do processo, há medida que a distribuição de poder, implica necessariamente perdas e ganhos, com resistências, principalmente, do nível central - cujos "domínios" se limitam - mas também dos níveis subnacionais - cujas responsabilidades se elevam. Um segundo problema envolve o típico conservadorismo da burocracia, tendente a resistir quaisquer movimentos de mudança. Outras dificuldades sinalizadas pela autora consistem no traço psicosócio-cultural da sociedade brasileira, que leva à predominância de visão de curto prazo, em detrimento de uma perspectiva de médio ou longo alcance; a defesa de uma radicalização da descentralização para os municípios, em que se advoga que todos os serviços deveriam ser descentralizados a estas instâncias; e o 
regionalismo, tendente a requerer que os benefícios sejam dirigidos prioritariamente para suas regiões específicas, numa tentativa de assegurar maiores ganhos da descentralização financeira.

Para Abrúcio (2005), a descentralização requer um projeto nacional e a construção de novas capacidades das esferas governamentais, inclusive do governo federal, que deve se habilitar para o exercício da coordenação federativa. Esta função, no contexto federativo, consiste em adotar formas de integração, compartilhamento e decisão entre os entes federados, mediante regras legais, fóruns e mecanismos políticos de negociação intergovernamental, funcionamento de instituições representativas.

Kugelmas e Sola (1999) levantam questão sobre os efetivos benefícios da descentralização, num contexto em que faltam aos estados e municípios condições administrativas, financeiras e institucionais para implementar programas, bem como em que há precariedade dos mecanismos de accountability. Para os autores, as esperadas vantagens da descentralização não depende somente de definições institucionais, mas de um contexto social e cultural mais amplo.

Segundo Arretche (1997), o processo de descentralização não implica na simples redução da máquina administrativa federal, pois supõe o fortalecimento de sua capacidade administrativa e do seu poder decisório para comandar e coordenar o processo e as políticas sociais a serem desenvolvidas.

Draibe (1997) destaca que para o processo de descentralização funcionar de maneira sólida seria preciso observar algumas exigências, tais como:

(...)uma política explícita, coordenada e contínua, o que supõe um "centro" dotado de boa capacidade de condução; a adequada simetria entre descentralização fiscal e descentralização de competências e encargos; a construção de capacidades administrativas nos níveis descentralizados em que passam a operar os programas; a introdução de sistemas ágeis de monitoramento, avaliação e circulação da informação. (...)Do ponto de vista da eqüidade, é fundamental que os processos de descentralização não suprimam nem esvaziem, no "centro", suas funções redistributivas e sua capacidade corretora das desigualdades regionais e individuais. (DRAIBE, 1997, p. 13)

Requisitos elementares para consecução do processo descentralização, segundo Lobo (1990), seriam a flexibilidade, de modo a considerar as distinções 
econômico-financeiras, políticas, técnico-administrativas e sociais dos governos subnacionais, os quais possuem distintas capacidades de resposta às demandas que se Ihes apresentam; o gradualismo, no sentido de que o processo se efetive de modo progressivo, respeitada a adequação do tempo/espaço; transparência no processo decisório, de maneira que o acordo, o pacto e a cooperação mútua para modificação das "regras do jogo"; e criação de mecanismos de controle social, viabilizando que a população participe do processo. Sobre estes dois últimos aspectos, a autora destaca:

(...) a inserção [dos governos subnacionais] no processo decisório de implantação dos programas descentralizados, é definitivo para o encaminhamento e consolidação dos mesmos. Do contrário, ter-se-á a reprodução de situações já conhecidas, onde boas ideias e ações federais se tornaram inócuas por não contarem com a adesão consciente e compromissada dos agentes a elas destinadas. (...) Não há porque descentralizar se quiser-se manter intacto o poder absoluto do Estado, mesmo em sua manifestação regional ou local (...) é preciso que o mesmo abra suas portas à participação da população organizada (LOBO, 1990, p. 9)

Embora a descentralização se constitua meio jurídico apropriado para a afirmação de vários centros de poder, vez que nos níveis locais os problemas são mais facilmente identificáveis e as possibilidades de participação são maiores, Baeta (1989) destaca que para dar consistência efetiva ao pluralismo ela depende da efetividade deste, requerendo estruturas políticas e administrativas, que reconheçam os agentes representativos das diferentes forças da sociedade com "partes" do processo. Nas palavras do autor:

(...) descentralização administrativa, como meio de consolidação democrática, não se esgota numa questão formal, que se coloca em termos normativos, mas está relacionada ao dinamismo da sociedade. (...) a substituição das estruturas institucionais, conquanto seja um passo à frente em direção à democratização do aparelho do Estado, não garante a necessária aproximação entre o Estado e a sociedade civil. A efetivação do diálogo entre as forças populares e os governantes requer a institucionalização das práticas de participação popular. (BAETA, 1989, p. 102)

\subsection{A descentralização nas políticas educacionais do Brasil.}


No âmbito da educação, as amplas reformas educacionais que sucederam na década de 1990 tiveram grande influência das orientações dos organismos internacionais como Banco Mundial, Comissão Econômica para a América Latina e o Caribe (CEPAL) e Organização das Nações Unidas para a Educação, a Ciência e a Cultura (UNESCO) (FRIGOTTO; CIAVATTA, 2003).

Como salienta Bassi (1996), porém, a efetivação de modelos descentralizados para educação também constituía "bandeira" dos setores progressistas da sociedade brasileira em oposição à ditadura militar e em defesa de princípios democráticos.

Conforme Krawczyc (2000), no mesmo viés que orientou as reformas que se impuseram aos Estados Nacionais, a educação assumiu um caráter instrumental subordinado à lógica econômica. Assim, o modelo gerencial de administração pública - com suas orientações voltadas a descentralização e à adoção de mecanismos de mercado no setor público - estendeu-se, de igual forma, às políticas educacionais (NOMA, 2011).

Apesar do reconhecimento formal, pelos organismos internacionais, de que as ações que propunham deveriam ser ajustadas às condições objetivas dos países (políticas, sociais, culturais, etc.), Lauglo (1997) acentua a concepção homogeneizadora por trás dessas estratégias, que induziram os países a desenvolverem projetos na direção "que o Banco, em sua sabedoria, estabelecer" (LAUGLO, 1997, p. 12). Credita-se a essa indução homogeneizadora o enfoque dado pelos países à educação formal, especialmente à educação fundamental, e à descentralização como principal ferramenta para implantação das reformas educacionais (SOUZA, 2003; TIRAMONTI, 1997).

Embora situe-se no mesmo movimento de descentralização que alcança outras áreas sociais, no contexto educacional esse processo assume traços ainda mais marcantes, vez que não se resume à transferência de poderes administrativos e financeiros aos entes subnacionais (estados e municípios), como também fixa bases para ampliação da autonomia de gestão das próprias unidades de ensino, instigando a participação da sociedade civil no financiamento e execução dos serviços educacionais (NOMA, 2011). Sacristán (1997, p. 36) ressalta que os 
movimentos por trás das reformas descentralizadoras na educação podem apreciarse em quatro aspectos:

[...] a) a distribuição do poder de decisão e controle entre as autoridades centrais e locais. [...]; o surgimento e reconhecimento dos estabelecimentos escolares como verdadeiras unidades de inovação, elementos estratégicos para centrar as políticas de mudança e reforma; c) os movimentos e propostas que afetam a autonomia dos docentes [...]; d) os movimentos de reivindicação dos pais para uma maior intervenção, junto a outros agentes sociais, no controle do desenvolvimento dos estabelecimentos escolares. (SACRISTÁN, 1997, p. 36).

$\mathrm{Na}$ perspectiva econômica, esse "empoderamento" local preconizado pelas reformas descentralizadoras partiu do pressuposto de que, sendo a educação uma responsabilidade social, o encargo pela captação de recursos e provisão dos serviços públicos não deveria ser unicamente do Estado, mas de toda a sociedade, segundo uma concepção de gestão compartilhada (NOMA, 2011). Esperava-se, ainda, que esse processo conferiria às escolas maior flexibilidade para adaptar-se às necessidades de seus clientes (BARROSO, 1996).

Segundo Souza (2003), a prevalência do caráter gerencial sobre os anseios de maior democratização na educação manifesta a conformação delegatória da descentralização que se efetiva no contexto educacional. $O$ autor insiste que, embora se tenha proporcionado mecanismos de participação dos níveis mais locais, "esta participação não está posta nos processos de efetiva decisão das questões mais centrais da vida da escola. Ela atua mais na implementação ou direção daquilo que já está previamente decidido" (SOUZA, 2003, p. 10). O processo descentralizador aos estabelecimentos de ensino, como ressalta o próprio autor, aproximar-se-ia mais do que Rivas (1991, p. 20) define como desconcentração:

Por desconcentración se entiende la administración del sistema en que el Estado central delega determinadas funciones a entidades regionales o locales que dependen directamente de los ministerios centrales, pero manteniendo concentrado en su poder la toma de decisiones sobre todos los aspectos antes señalados y la facultad para otorgar, modificar e retirar atribuciones a los funcionarios de estas reparticiones o simplemente removerlos. La delegación de funciones de operativas se hace a organismos que no son autónomos sino que están bajo la dependencia directa del poder central. Por descentralización se entiende aquella situación en la que diversas entidades regionales y locales (de gobierno o corporaciones autónomas) con grados significativos de autonomía, definen las 
formas propias en que se debiera organizar y administrar el sistema de educación pública en sus respectivas áreas. En la descentralización ya no hay solo una delegación de facultades operativas, sino también el ejercicio de un poder de decisión real sobre aspectos importantes del manejo financiero, la elaboración del currículo local y a la administración y gestión educacionales en zonas geográficas determinadas (RIVAS, 1991, p. 20).

Os principais propósitos das reformas, cujo instrumento chave foi a descentralização, conforme Carnoy e Castro (1997), consistiram na redução de custos do governo nacional com a educação, organização mais eficaz do aproveitamento escolar, alinhada à produção de capital humano, e diminuição da desigualdade na distribuição da qualidade de ensino.

Apesar da observada redução nos custos nacionais com a educação, constatou-se diminuição na qualidade do ensino e aumento da desigualdade na fruição da pouca qualidade existente, situação motivada, ainda que não linearmente, pelo paradoxo de redução do financiamento público e ampliação do público atendido (massificação) (CARNOY; CASTRO, 1997).

Segundo Dourado (2013), o processo de descentralização que sucedeu no Brasil é bastante complexo. Envolveu diferentes esferas, sistemas de ensino e unidades educativas, bem como políticas, programas e ações sobre a organização, gestão e financiamento da educação, em um cenário marcado pela diversificação e diferenciação institucional e balizado por assimetrias regionais. Para o autor, há necessidade de um novo esforço e um pacto federativo assentado:

[...] na efetiva coordenação e cooperação, para a maior organicidade entre os processos, as políticas e programas educacionais, a gestão e o financiamento, e para a democratização da organização e gestão educacional, incluindo a ampliação do direito e a regulação. (DOURADO, 2013, p. 772)

Diante disso, nos últimos anos tem ganhando centralidade nos debates educacionais do país, a concepção e operação de um Sistema Nacional de Educação no Brasil; temática que, segundo o Ministério da Educação, constitui "agenda obrigatória para o país" (BRASIL, 2015c). Para Gracindo (2010), a instituição de um Sistema Nacional de Educação, como posição política e forma de 
gestão, pode propiciar organicidade e articulação na proposição e materialização das políticas educativas.

Conforme a autora, a lógica organizativa fragmentada e desarticulada em que se funda o projeto educacional brasileiro contribui para manutenção de quadros de exclusão, alto índice de analfabetismo, pouca escolaridade dos brasileiros, frágil desempenho dos estudantes, não universalização da educação básica e não democratização do acesso à educação superior (GRACINDO, 2010).

A ausência de um sistema nacional tem resultado em graves fragilidades para a educação do país, como a ausência de referenciais nacionais de qualidade capazes de orientar a ação supletiva para a busca da equidade, a descontinuidade de ações, a fragmentação de programas e a falta de articulação entre as esferas de governo, contribuindo para manutenção das históricas desigualdades econômicas e sociais do país (BRASIL, 2015c).

As medidas e tentativas de cooperação para buscar maior organicidade das políticas, programas e ações postas pela União nos últimos anos, segundo Dourado (2013), vêm se constituindo, em sua maioria, em processos com reduzida intervenção dos entes federados, tendo sua adesão motivada por mecanismos de indução financeira. Assim, "esse contexto, se não for revisto, poderá contribuir, cada vez mais, para a centralização do poder e para a consequente redução de autonomia dos governos subnacionais" (DOURADO, 2013, p. 769).

Assim, as propostas em torno de um Sistema Nacional de Educação visam assegurar meios para alcançar o que Dourado (2013) designa como "descentralização qualificada", cuja missão é a oferta educacional que equilibra qualidade com equidade e identidade nacional com identidade local (BRASIL, 2015c). Nesse sentido, instrumentos de planejamento e pactuação entre as esferas de governo podem assumir papel central para alcance de resultados não restritos apenas às redes de ensino, concretizando as ações articuladas no território (idem). "Esse cenário tem como condição o planejamento integrado, referenciado pelo Plano Nacional de Educação e pelos planos subnacionais aprovados em consonância com seus dispositivos" (BRASIL, 2015c, p. 10). 


\subsection{Formulação e avaliação de políticas públicas.}

As políticas públicas consistem na atuação do Estado para alcance de algum objetivo. Conforme Höfling (2001), as políticas públicas podem ser entendidas como "o Estado implantando um projeto de governo, através de programas, de ações voltadas para setores específicos da sociedade". Para Dye (1984), as políticas públicas podem ser compreendidas como aquilo que "o governo escolhe fazer ou não fazer".

As convulsões econômicas, sociais e políticas que sucederam, sobretudo a partir da década de 1970, ao induzirem questionamentos quanto aos papéis atribuídos ao Estado e à eficácia de suas ações sobre a realidade social, apontaram para a relevância de que sejam compreendidos os aspectos relativos ao "sucesso" e "fracasso" das políticas públicas (TREVISAN; BELLEM, 2008). A adoção de políticas restritivas de gasto, em substituição às políticas keynesinas do pós-guerra, como consequência das novas visões sobre o papel dos governos, contribuíram para dar maior visibilidade ao estudo do desenho e da execução de políticas públicas, tanto as econômicas como as sociais (SOUZA, 2006).

De acordo com Faria (2003), em seus primórdios, os estudos de políticas públicas concentravam-se majoritariamente nos processos de formação das políticas, isto é, nas demandas e articulações de interesse do sistema político. Assim, as políticas eram vistas, basicamente, como outputs desse sistema, refletindo "o status privilegiado que os processos decisórios sempre desfrutaram junto aos profissionais da área" (FARIA, 2003, p. 21).

Segundo o autor, a partir da década de 1950, passou-se à definição das próprias políticas públicas como unidade de análise, o que gradualmente conferiu destaque aos aspectos dinâmicos do processo da política e aos distintos atores, estatais e não estatais envolvidos (FARIA, 2003).

Embora a propagação desses estudos tenha resultado no que Faria (2003) chama de "Babel de abordagens, teorizações incipientes e vertentes analíticas que buscam dar inteligibilidade à diversificação dos processos de formação e gestão das políticas públicas" (FARIA, 2003, p. 22), algumas categorias de análise têm 
conseguido relevância na literatura, como as sistematizadas por Viana (1996) e Frey (2000). Uma das principais, o modelo policy cycle (ciclo de políticas) considera que o agir público pode ser analisado com base em fases parciais do processo políticoadministrativo de resolução de problemas. Apesar das variações existentes na literatura sobre o número e especificação dessas etapas, Frey (2000) aponta que, em síntese, todas abrangem, com maior ou menor especificidade, as fases de formulação, implementação e controle dos impactos das políticas.

Do ponto de vista analítico, o autor considera ser mais sofisticada uma subdivisão que considere as seguintes fases: percepção e definição de problemas, agenda-setting, elaboração de programas e decisão, implementação de políticas e, finalmente, avaliação de políticas com eventual correção da ação (FREY, 2000). Embora ressalte que os atores político-administrativos dificilmente se fixam a esse contínuo, o autor indica que o policy cycle pode servir como um quadro de referência para a análise processual das políticas públicas.

A primeira etapa consistiria na percepção ou definição de problemas que chamam a atenção do governo e dos cidadãos. Nesse sentido, interessaria compreender como que, em um número infinito de possíveis campos de ação política, alguns problemas se mostram apropriados para um tratamento político e acabam gerando o start do processo do policy cycle. Trata-se de analisar como, ou sob que condições, determinadas questões alcançam relevância política e administrativa, passando a ser vistas como problemas sociais (idem).

A etapa seguinte (agenda-setting) envolve a configuração da agenda política, isto é, a definição da lista de problemas ou assuntos prioritários que comporão a pauta política do governo, passíveis de induzir a concepção de políticas (idem). Segundo Viana (1996), a constituição da agenda governamental pode decorrer da ocorrência de eventos dramáticos, crises, influência de um quadro de indicadores ou acumulação de informações ou experiências.

$\mathrm{Na}$ fase de elaboração de programas e de decisão é quando ocorre a especificação das alternativas de ação e escolha daquela considerada mais apropriada (FREY, 2000). Segundo o autor, os conflitos, as articulações e os compromissos negociados anteriormente ao ato de decisão propriamente dito, 
geralmente, tolhem a "liberdade" real dos tomadores de decisão. Isto é, escolhas entre várias alternativas de ação seriam raras exceções nessa fase do ciclo político. Vianna (1996), ao descrever a perspectiva analítica de Hoppe, Van de Graaf e Van Dijk (1985), ressalta que o processo de formulação pode ser desmembrado, ainda, em três subfases: a primeira, quando uma massa de dados transforma-se em informações relevantes; a segunda, quando valores, ideais, princípios e ideologias se combinam com informações factuais para produzir conhecimento sobre ação orientada; e a última, quando o conhecimento empírico e normativo é transformado em ações públicas.

A próxima etapa do policy cycle, a implementação de políticas, consiste na efetivação da ação estipulada na fase anterior. O maior interesse em sua análise deve-se ao fato de que, muitas vezes, os resultados e impactos reais de certas políticas não correspondem àqueles projetados na fase de formulação (FREY, 2000). De acordo com o autor, é possível identificar duas abordagens de análise dos processos de implementação de políticas públicas:

[...] a análise da qualidade material e técnica de projetos ou programas, [...] [...] [e a análise] direcionada para as estruturas político-administrativas e a atuação dos atores envolvidos. No primeiro caso, tem-se em vista, antes de mais nada, o conteúdo dos programas e planos. Comparando os fins estipulados na formulação dos programas com os resultados alcançados, examina-se até que ponto a encomenda de ação foi cumprida e quais as causas de eventuais déficits de implementação. No segundo caso, o que está em primeiro plano é o processo de implementação, isto é, a descrição do como e da explicação do porquê (FREY, 2000, p. 228).

Segundo Viana (1996), o "sucesso" das políticas depende do quão perfeita é a interação entre formuladores, implementadores e o público alvo das ações, reafirmando que os problemas da relação formulação-implementação estão na desconexão entre os níveis de conhecimento desses agentes. Nesse mesmo sentido, o autor considera que a efetivação das metas e dos objetivos das políticas é influenciada pelo nível de consenso entre os participantes (implementadores e formuladores), disposição essa dependente das características das agências de implementação, das condições políticas, econômicas e sociais, e da forma de execução de atividades. 
$\mathrm{Na}$ última fase, da avaliação de políticas e correção de ação, os programas implementados devem ser apreciados no tocante a seus impactos. Verificam-se eventuais déficits de impacto e efeitos colaterais indesejados para poder deduzir consequências para ações e programas futuros, sendo "imprescindível para o desenvolvimento e a adaptação contínua das formas e instrumentos de ação pública" (FREY, 2000, p. 229).

De acordo com Ala-Harja e Helgason (2000, p. 5), "a avaliação de um programa pode ser definida como uma análise sistemática de aspectos importantes de um programa e seu valor, visando fornecer resultados confiáveis e utilizáveis". Trata-se de mecanismo útil para melhoria no processo de tomada de decisão, por intermédio da obtenção de informações aos governantes que possam fundamentar suas decisões, melhorar a concepção de um programa e sua implementação (ALAHARJA; HELGASON, 2000).

Não obstante a grande utilidade das informações provindas da avaliação, Trevisan e Bellen (2008) afirmam que esta é muito pouco utilizada. E pode ser percebida até como um "problema" para os governantes, executores e gerentes de projetos à medida que seus resultados possam ser usados pelo público e pela imprensa para criticá-los, causando constrangimentos públicos. Nesse viés, Faria (2003) destaca a rara utilização da avaliação, como instrumento de gestão, pelo setor público do Brasil nas três esferas de governo, o que favorece a notória carência de estudos dedicados aos processos e às metodologias de avaliação (FARIA, 2003).

De acordo com Cotta (2001, p. 91), no âmbito da literatura, a avaliação tem sido classificada:

(...) em função do seu timing (antes, durante ou depois da implementação da política ou programa), da posição do avaliador em relação ao objeto avaliado (interna, externa ou semi-independente) e da natureza do objeto avaliado (contexto, insumos, processo e resultados). (COTTA, 2001, p. 91)

As avaliações ex-ante, anteriores à implementação da política, consistem em análises de custo-benefício, de custo-efetividade, das taxas de retorno econômico dos investimentos previstos e foram muito estimuladas e induzidas pelos organismos internacionais de financiamento (RICO ET. AL., 1998). A avaliação que é conduzida 
durante a implementação de um programa, também chamada de formativa, constitui meio de se adquirir mais conhecimento para dar suporte e melhorar a gestão, a implementação e o desenvolvimento do programa, com ênfase na aplicabilidade direta dos resultados (ALA-HARJA; HELGASON, 2000). As avaliações ex-post ou somativas, que são posteriores à implementação do programa, visam verificar os impactos e processos, focando a eficácia e o julgamento do valor geral do programa. A objetividade e a credibilidade dos achados são mais importantes que a aplicabilidade direta dos resultados (RICO ET. AL., 1998; ALA-HARJA; HELGASON, 2000).

No que diz respeito à posição do avaliador ante o objeto avaliado, Arretche (1998) defende que as avaliações precisam ser conduzidas por órgãos externos àqueles responsáveis pelas políticas, com vistas a conferir maior neutralidade da avaliação. Ainda que neutralidade absoluta não exista, para a autora é muito difícil que avaliações realizadas pelas próprias equipes governamentais encarregadas da execução das políticas não sejam mais tendentes a conclusões que afirmem o sucesso do programa ou que minimizem seus elementos de fracasso, até mesmo como forma de manutenção dos próprios empregos ou de aumentar suas margens de poder e gasto. Por isso, é mais difícil que essas "avaliações" tenham valor avaliativo, ainda que possam ser bons instrumentos de pesquisa para estudos de avaliação (ARRETCHE, 1998, p. 37-38).

Quanto aos objetivos de uma avaliação de política pública, podem-se distinguir três modalidades: avaliação de metas, avaliação de processos e avaliação de impacto (CARVALHO, 2003; COSTA; CASTANHAR, 2003).

A avaliação de metas tem como propósito mensurar o grau de êxito que um programa alcança, isto é, seus resultados mais imediatos - número de pessoas atendidas em centros de saúde, número de horas de aula, número de leitos hospitalares (TREVISAN; BELLEN, 2008). Algumas das limitações desse tipo de avaliação descritas por Costa e Castanhar (2003) são: dificuldade de especificar as metas de forma precisa; seleção de metas a serem incluídas no processo de avaliação; mudanças nas metas ao longo da própria execução do programa. A avaliação de processo, por sua vez, visa: 
[...] detectar defeitos na elaboração dos procedimentos, acompanhar e avaliar a execução dos procedimentos de implantação dos programas, identificar barreiras e obstáculos à sua implementação e gerar dados para sua reprogramação, por meio do registro de intercorrências e de atividades. (TREVISAN; BELLEN, 2008, p. 546)

A avaliação de impacto, segundo Carvalho (2003, p. 186), "é aquela que focaliza os efeitos ou impactos produzidos sobre a sociedade e, portanto, para além dos beneficiários diretos da intervenção pública, avaliando-se sua efetividade social". Essa avaliação visa detectar as mudanças que ocorreram, em que medida as mudanças ocorreram na direção desejada e a relação causal entre o programa e a mudança social provocada (CARVALHO, 2003; COSTA; CASTANHAR, 2003).

Por fim, deve-se considerar que, sendo a avaliação o ato de atribuir valor a algo em relação a certo parâmetro, há necessidade de definição dos critérios pelos quais se deve julgar. Para tanto, Costa e Castanhar (2003, p. 973) listam os mais comumente utilizados: eficiência, eficácia, efetividade, sustentabilidade, análise custo-efetividade, satisfação do usuário, equidade. Segundo os autores, a operacionalização desses critérios pode ser feita por meio de indicadores, os quais são medidas usadas para viabilizar a operacionalização de um conceito abstrato ou de uma demanda de interesse programático (JANNUZZI, 2014).

\section{PERCURSO METODOLÓGICO}

\subsection{Tipo de pesquisa}

Uma forma preliminar de demonstrar o delineamento metodológico da pesquisa consiste em classificar a pesquisa realizada, a partir de determinadas perspectivas.

Segundo Gil (2008), quanto aos objetivos, a pesquisa pode ser classificada como descritiva sempre que o propósito for descrever características de determinada população ou fenômeno, bem como identificar associações entre as variáveis. Nesse sentido, esta investigação envolve justamente a descrição dos déficits de infraestrutura dos estabelecimentos de ensino do Brasil, bem como verificação de eventual associação entre essas condições e os valores financeiros destinados às referidas unidades escolares. 
No que se refere aos procedimentos, a pesquisa pode ser considerada levantamento amostral, vez que utiliza-se de informações colhidas de grupo significativo de indivíduos - nesse caso, escolas - que fornecem dados, que viabilizam a efetivação posterior de análises quantitativas (GIL, 2008; GERHARDT E SILVEIRA, 2009).

Quanto à abordagem, de acordo com Gil (2008), Gerhardt e Silveira (2009) a pesquisa pode ser considerada como quantitativa, vez que os resultados podem ser quantificados, efetivando-se com auxílio de instrumentos padronizados e neutros, recorrendo à linguagem matemática para descrever um fenômenos.

Algumas das vantagens do tipo de pesquisa adotado, conforme Gerhardt e Silveira (2009), Fonseca (2002) e Polit et. Al (2004), está a mais facilitada descrição dos fenômenos, dentro da sua incompletude; economia e rapidez, vez que é possível obter grande quantidade de dados em curto espaço de tempo; quantificação, à medida que os dados levantados são passíveis de tabulação e análises estatísticas; e objetividade na coleta e análise de dados, reduzindo o efeito da subjetiva do pesquisador.

\subsection{Variáveis utilizadas e fontes de dados}

Para consecução das análises quantitativas foram utilizados dados relativos:

a) às condições de infraestrutura física das escolas públicas do país em 2014, disponíveis no sistema PDDE Interativo, mantido pelo Ministério da Educação;

b) às características gerais das escolas objeto do estudo - número de alunos atendidos, níveis de ensino, jornada escolar e localização dos - levantados pelo Censo Escolar de 2014, realizado pelo Instituto Nacional de Estudos e Pesquisas Educacionais Anísio Teixeira (Inep);

c) às características gerais dos municípios onde se situam as escolas - região geográfica, unidade da federação, estimativa de número de habitantes e índice de desenvolvimento humano - provenientes do Instituto Brasileiro de Geografia e Estatística (IBGE); e 
d) aos valores destinados aos estabelecimentos escolares pelo PDDE e suas ações agregadas, em 2014, disponíveis no Sistema de Ações Educacionais, do Fundo Nacional de Desenvolvimento da Educação (FNDE).

O PDDE Interativo consiste numa sistema eletrônico concebido e mantido pelo Ministério da Educação, em parceria com secretarias municipais e estaduais de educação, para "auxiliar a comunidade escolar a produzir um diagnóstico de sua realidade e a definir ações para aprimorar sua gestão e seu processo de ensino e aprendizagem" (BRASIL, 2013g). De acordo com o Ministério, a ferramenta foi disponibilizada a todas as escolas públicas da educação básica, independentemente de serem beneficiárias de programas federais, sendo de preenchimento facultativo (BRASIL, 2015a), tendo principal característica sua:

[...] natureza autoinstrucional e interativa [...] estimulando a reflexão sobre os temas abordados [...] [o PDDE Interativo] está organizado em etapas que ajudam a equipe escolar a identificar seus principais problemas e a definir ações para alcançar os seus objetivos, aprimorar a qualidade do ensino e da aprendizagem e melhorar os seus resultados (BRASIL, 2015b).

A ferramenta é organizada em quatro partes: a primeira, destina-se à identificação de informações gerais da escola e de seu dirigente; a segunda volta-se a identificar os agentes do Grupo de Trabalho (GT) que a escola deve constituir para elaboração do diagnóstico e, posteriormente, do plano de ações. A terceira etapa, o diagnóstico, tem por objetivo ajudar a escola a fazer o seu "raio X", ou seja, "conhecer a situação presente e, a cada momento, tentar identificar os principais problemas e desafios a serem superados" (BRASIL, 2013g, p. 6). E a última fase consiste no planejamento, em que a unidade de ensino, diante dos problemas detectados na etapa anterior, define objetivos, metas, estratégias e ações para superação dos problemas considerados prioritários (BRASIL, 2013g).

Conforme demonstra o Quadro 4, o diagnóstico abrange informações sobre diversos aspectos da escola, os quais são organizados em seis dimensões, estruturadas em três eixos temáticos (idem). Na última fase do diagnóstico, as escolas preenchem informações sobre as condições de infraestrutura escolar, apontando o quantitativo e a percepção da comunidades quanto adequação de determinadas instalações físicas, equipamentos e mobiliários (idem). Para o presente estudo, foram considerados os dados que informam a quantidade de itens 
de infraestrutura das escolas, dado o caráter mais objetivo da informação, que favorece a comparabilidade das condições de funcionamento entre as escolas.

Quadro 4: Eixos, dimensões e temas abrangidos pelo sistema de informação PDDE Interativo.

\begin{tabular}{|c|c|c|}
\hline Eixo & Dimensões & Temas \\
\hline \multirow{7}{*}{ Resultados } & \multirow{3}{*}{ Indicadores e Taxas } & IDEB \\
\hline & & Taxas de Rendimento \\
\hline & & Prova Brasil \\
\hline & \multirow{4}{*}{ Distorção e Aproveitamento } & Matrícula \\
\hline & & Distorção Idade-Série \\
\hline & & Aproveitamento Escolar \\
\hline & & Áreas de Conhecimento \\
\hline \multirow{5}{*}{$\begin{array}{l}\text { Intervenção } \\
\text { Direta }\end{array}$} & \multirow{2}{*}{ Ensino e Aprendizagem } & $\begin{array}{l}\text { Planejamento } \\
\text { Pedagógico }\end{array}$ \\
\hline & & $\begin{array}{l}\text { Tempo de } \\
\text { Aprendizagem }\end{array}$ \\
\hline & \multirow{3}{*}{ Gestão } & Direção \\
\hline & & Processos \\
\hline & & Finanças \\
\hline \multirow{7}{*}{$\begin{array}{l}\text { Intervenção } \\
\text { Indireta }\end{array}$} & \multirow{5}{*}{ Comunidade Escolar } & Educandos \\
\hline & & Docentes \\
\hline & & Demais Profissionais \\
\hline & & Pais e Comunidade \\
\hline & & Conselho Escolar \\
\hline & \multirow{2}{*}{ Infraestrutura } & Instalações \\
\hline & & Equipamentos \\
\hline
\end{tabular}

Fonte: Brasil. Ministério da Educação. Manual do PDDE Interativo 2013.

O Censo Escolar, por sua vez, é o principal instrumento de coleta de informações da educação básica, realizado, anualmente, pelo INEP em regime de colaboração com as secretarias estaduais e municipais de educação, e com a participação de todas as escolas públicas e privadas do país (BRASIL, 2017a). Segundo o Instituto, a coleta de dados das escolas tem caráter declaratório abrangendo informações sobre os estabelecimentos de ensino, turmas, alunos e profissionais escolares em sala de aula (idem).

Os dados característicos dos municípios provem do último Censo Demográfico do IBGE, de 2010, com estimativas populacionais atualizadas para 2015. O Índice de Desenvolvimento Humano Municipal (IDH-M), calculado segundo metodologia proposta pelo Programa das Nações Unidas para o Desenvolvimento (PNUD) no Brasil, pelo Instituto de Pesquisa Econômica Aplicada (IPEA) e pela 
Fundação João Pinheiro considera três dimensões representativas do desenvolvimento humano - longevidade, educação e renda (PNUD, 2017).

Já o Sistema de Ações Educacionais constitui repositório administrativo de dados do FNDE sobre atendimento e transferências financeiras do PDDE e de suas ações agregadas, com módulo de acesso às informações pelo público externo.

Como observado, as três fontes de dados utilizadas para as análises são oriundas do próprio Ministério da Educação e de suas Autarquias, o que ressalta a riqueza e possibilidades de uso de registros administrativos das instituições públicas para realização de estudos avaliativos com vistas ao aperfeiçoamento das ações programáticas.

O Quadro 5, apresenta síntese das variáveis consideradas para realização do estudo, cuja escolha foi determinada, sobretudo, pela disponibilidade de dados nas fontes oficiais, abrangência das informações - para propiciar levantamento de larga escala -, e possibilidades de replicação futura, para realização de comparativos.

Quadro 5: Variáveis e fontes de dados selecionados para realização das análises estatísticas.

\begin{tabular}{|c|c|c|c|}
\hline Grupo & Variáveis & Fonte de dados & $\begin{array}{c}\text { Ano da } \\
\text { informação }\end{array}$ \\
\hline $\begin{array}{l}\text { Condições de } \\
\text { Infraestrutura das } \\
\text { escolas }\end{array}$ & $\begin{array}{l}\text { Instalações Físicas: № de Salas de aula, Sanitário } \\
\text { dos estudantes, Sala de professores, Biblioteca/Sala } \\
\text { de leitura, Refeitório, Cozinha, Quadra de esportes } \\
\text { coberta, Depósito de material de limpeza, Sala de TV } \\
\text { e vídeo, Laboratório de informática, Laboratório de } \\
\text { ciências } \\
\text { Mobiliário: № de Cadeiras, Carteiras, Suportes para } \\
\text { TV e DVD, Quadros para sala de aula, Arquivos de } \\
\text { aço, Armários, Mesas tipo escrivaninha, Estantes para } \\
\text { biblioteca, Mesas para impressora, Mesas para } \\
\text { computador, Mesas para refeitório, Mesas de leitura, } \\
\text { Mesas de reunião da sala de professores, Armários } \\
\text { para secretaria. } \\
\text { Equipamentos: № de Televisores, Aparelhos de } \\
\text { DVD, Aparelhos de CD e rádio, Circuladores de ar, } \\
\text { Computadores para administração/docentes, } \\
\text { Computadores para sala de informática, } \\
\text { Retroprojetores, Telas para projeção, Bebedouros } \\
\text { elétricos, Freezers, Geladeiras, Fogão(ões) } \\
\text { industrial(ais), Liquidificador(es) industrial (ais), } \\
\text { Botijão(ões) de gás, Máquinas fotográficas, } \\
\text { Impressoras laser, Impressoras jato de tinta, } \\
\text { Fotocopiadoras, Guilhotinas de papel, Máquinas de } \\
\text { lavar roupa, Aparelhos de telefone. }\end{array}$ & PDDE Interativo & 2014 \\
\hline $\begin{array}{l}\text { Características } \\
\text { gerais das } \\
\text { escolas }\end{array}$ & $\begin{array}{l}\text { № de alunos, jornada escolar (parcial/integral), nível } \\
\text { de ensino (infantil, fundamental e médio), } \\
\text { dependência administrativa e e localização } \\
\text { (urbana/rural) das escolas. }\end{array}$ & Censo Escolar & 2014 \\
\hline $\begin{array}{l}\text { Valores } \\
\text { destinados às } \\
\text { escolas }\end{array}$ & $\begin{array}{l}\text { Valores monetários repassados pelo PDDE e suas } \\
\text { ações, destinado para realização de despesas de } \\
\text { custeio (serviços e materiais) e capital (equipamentos } \\
\text { e mobiliário) }\end{array}$ & $\begin{array}{l}\text { Sistema de Ações } \\
\text { Educacionais }\end{array}$ & 2014 \\
\hline $\begin{array}{l}\text { Características } \\
\text { gerais dos entes } \\
\text { federados }\end{array}$ & $\begin{array}{l}\text { Região geográfica, unidade da Federação, número de } \\
\text { habitantes em 2015, Índice de Desenvolvimento } \\
\text { Humano (IDH-M) 2010 }\end{array}$ & IBGE & 2010 e 2015 \\
\hline
\end{tabular}




\subsection{Amostragem}

Para realização das análises quantitativas, optou-se pela realização de amostragem não probabilística, composta de todas as escolas públicas urbanas do ensino fundamental que informaram, no sistema PDDE Interativo, os quantitativos de instalações físicas, mobiliários e equipamentos que dispunham em 2014.

Embora a intenção inicial do estudo fosse abranger todas as escolas públicas de educação básica (educ. infantil, ensino fund., e ens. médio), a alternativa de restringir a amostra mostrou-se mais pertinente para operacionalização do trabalho e qualidade dos resultados, especialmente na fase da Análise Fatorial. Como se verá a seguir, haja vista que os distintos níveis de ensino requerem itens específicos de infraestrutura, considerá-los indistintamente, numa mesma amostra, eleva substancialmente a heterogeneidade dos dados, comprometendo a qualidade da Análise Fatorial e, por conseguinte, não oferecendo resultados parcimoniosos. Assim, optou-se por restringir a amostra para contemplar somente as escolas públicas do ensino fundamental situadas na zona urbana.

Ainda assim, significativo número de estabelecimentos se enquadraram no critério: 20.050 escolas públicas, das redes estaduais e municipais de ensino, distribuídas em 4.125 municípios, de todas as Unidades da Federação, conforme demonstrado no Gráfico 3, apontando para a representatividade da amostra.

Gráfico 3: Percentual de escolas públicas de ensino fundamental, situadas em áreas urbanas, das redes municipais e estaduais, que informaram dados de infraestrutura física no sistema PDDE Interativo em 2014.

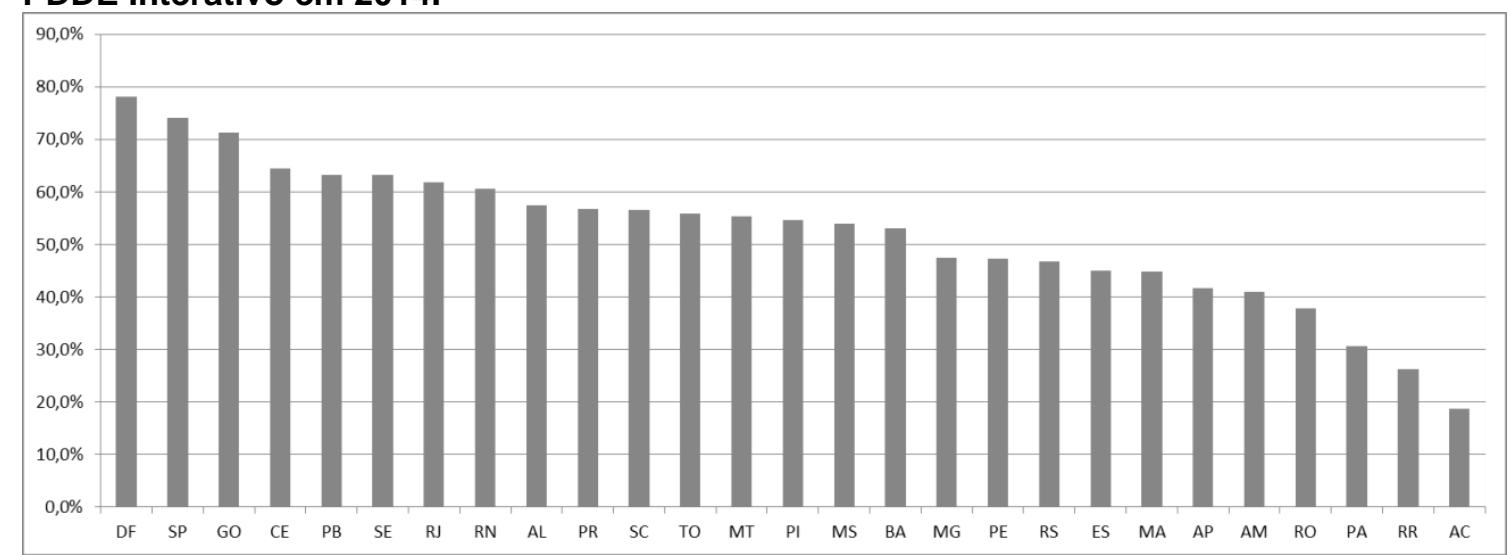

Fonte: Censo Escolar da Educação Básica. 2014. INEP. PDDE Interativo. 2014. MEC. Elaboração própria 


\subsection{Forma de cálculo dos déficits de infraestrutura e classificação das escolas}

Como se observou da literatura pesquisada, a quase totalidade dos estudos que se propuseram mensurar as condições de infraestrutura das escolas o fizeram verificando a existência, ou não, de certas instalações físicas nos estabelecimentos de ensino pesquisados, para posterior comparação de suas situações. No entanto, poucos foram os estudos que consideraram o fato de que não necessariamente todas as escolas precisam ter as mesmas variedades e quantidades de instalações físicas, equipamentos e mobiliários.

Conforme sinalizam os parâmetros mínimos de qualidade de infraestrutura escolar identificados na literatura, a quantidade mínima de insumos necessários para as escolas pode variar a depender do nível de ensino, jornada escolar, número de alunos e localização (urbana ou rural) da unidade educativa. Na prática, a desconsideração desses aspectos pode resultar na classificação de uma escola como "boa" em infraestrutura, apenas pelo fato de essa dispor de mais instalações/equipamentos/mobiliários que outra unidade de ensino; quando, à luz de um referencial de qualidade, ambas podem vir a ser consideradas deficitárias ou inadequadas - ainda que sob intensidades distintas. A ausência de um parâmetro de qualidade para avaliar as condições da infraestrutura das escolas, minimamente ajustado às diversidades das unidades de ensino, pode levar, por exemplo, à classificação de uma escola de educação infantil como sendo deficitária em infraestrutura por não possuir laboratório de ciências, quando esta instalação sequer é necessária para uma escola desse nível de ensino.

Desse modo, para classificação e análise das condições de infraestrutura escolar empreendidas neste trabalho foram considerados os parâmetros de qualidade propostos, em 2011, pela Campanha Nacional pelo Direito à Educação ${ }^{7}$ CNDE (2011). Dentre os parâmetros analisados, este demonstrou ser o mais adequado para os propósitos do trabalho, visto que contempla não apenas a variedade de instalações, equipamentos e mobiliários considerados mínimos para o funcionamento satisfatório das escolas, como também as quantidades necessárias

\footnotetext{
${ }^{7}$ Surgiu em 1999 impulsionada por um conjunto de organizações da sociedade civil que participaria da Cúpula Mundial de Educação em Dakar (Senegal), no ano 2000. É constituída por uma rede de grupos e entidades distribuídas por todo o país que atuam pela efetivação e ampliação das políticas educacionais para garantia do direito à educação pública de qualidade no Brasil.
} 
para viabilizar oferta educacional de qualidade para um número específico de alunos, um dado nível de ensino e uma específica jornada e localização escolar. Além disso, a maior parte dos itens recomendados pelos parâmetros podem ser mensurados a partir das informações disponíveis no sistema PDDE Interativo.

Apesar das vantagens, desafios foram encontrados para adoção dos referidos parâmetros. O primeiro decorreu do fato de que as variedades e quantidades mínimas de infraestrutura sugeridos por CNDE (2011) foram definidos considerando um número fixo e hipotético de alunos. Isto é, para estimar a infraestrutura mínima para funcionamento adequado de uma escola de ensino médio, por exemplo, idealizou-se uma unidade escolar com 900 alunos em turno parcial. Nesse caso, a escola precisaria de, no mínimo, 450 carteiras escolares, por exemplo. Ocorre que nem todas as escolas brasileiras possuem 900 alunos e, tampouco, todas funcionam em turno parcial, por conseguinte, nem todas as escolas precisam de - ou somente de - 450 carteiras. Ademais, há casos em que a escola apenas oferta jornada integral para parte de seus alunos, situação que, também, requer ajustamento nos parâmetros de qualidade do CNDE.

Diante disso, para compatibilizar o modelo à realidade brasileira - em que as escolas atendem a distintos números de alunos e com distintas jornadas escolares procedeu-se à identificação dos itens de infraestrutura recomendados pelo CNDE que variam de acordo com o número de alunos e/ou com a jornada escola e realizou-se estimativa da respectiva função matemática. O número de carteiras, por exemplo, pode ser estimado da seguinte forma: [número de alunos em jornada parcial] ${ }^{\star} 0,5+$ [número de alunos em jornada integral].

Outra limitação dos parâmetros mínimos de infraestrutura da CNDE (2011) para classificação das escolas brasileiras consiste no fato de que o modelo estimou os itens necessários considerando que as escolas apenas ofertariam um nível de ensino. Haja vista que, no caso brasileiro, é comum escolas ofertarem mais de um nível, uma alternativa para continuidade do trabalho seria conceber modelos de infraestrutura "híbrida" ajustados às escolas que ofertam, simultaneamente, mais de um nível de ensino. Outra seria restringir a amostra para contemplar somente escolas que ofertam um nível de ensino. Embora possível, a primeira alternativa exigiria esforço operacional específico para identificar os itens necessários para 
cada um dos diversos arranjos possíveis (ex. creche + pré; creche + fundamental; creche + médio; creche + pré + fundamental; etc.), empreendimento que poderia demandar mais tempo que o disponível para consecução do projeto. Dessa forma, optou-se pela segunda alternativa e apenas escolas do ensino fundamental foram consideradas para composição da amostra, visto que estas representam a maior parte das unidades escolares.

Com essas adequações foi possível definir parâmetro relativamente dinâmico para classificação das condições de infraestrutura físicas das escolas, mais ajustado às singularidades do contexto brasileiro e aos objetivos do trabalho. No Anexo I, estão indicadas instalações físicas, equipamentos e mobiliários considerados mínimos para o ensino fundamental urbano, de acordo com CNDE (2011), destacados os ajustes realizados nos itens cujo quantitativo mínimo constitui função do número de alunos/turmas e/ou jornada escolar.

Assim, com base nesses parâmetros, partiu-se do pressuposto de que uma escola pode ser considerada deficitária em termos de disponibilidade de infraestrutura física se não dispõe dos elementos mínimos recomendados, em conformidade com seu nível de ensino, número de alunos, jornada e localização escolar.

Dessa forma, para cada um dos 46 itens de infraestrutura considerados indicados no Quadro 5 -, calculou-se a diferença entre a quantidade recomendada pelos padrões mínimos e a quantidade existente na respectiva unidade de ensino. Por exemplo, se para uma escola for recomendado, no mínimo, 10 salas de aulas, mas possuir apenas 7 , esta tem um déficit de 3 salas de aulas ${ }^{8}$. Quanto maior esse gap, maior é o déficit da escola em relação ao correspondente item. Logo, as escolas que dispõem do item em quantidade igual ou superior à recomendada pelo parâmetro possuem déficit nulo naquele item.

Realizados os cálculos individualizados dos déficits para cada item de infraestrutura das escolas da amostra, procedeu-se à realização de Análise Fatorial, com vistas a reduzir a quantidade de variáveis e viabilizar a classificação das

\footnotetext{
${ }^{8}$ Evidentemente, maior precisão seria obtida caso se considerasse, também, as especificações dos ambientes escolares, no sentido de mensurar sua qualidade. No entanto, tais informações ainda não são levantadas nas fontes de dados pesquisadas.
} 
escolas. Como será detalhado no tópico seguinte, a Análise Fatorial possibilita estimar índices sintéticos representativos da estrutura latente de um conjunto de dados. Neste caso, a técnica possibilitará sintetizar o conjunto original de dados (com 46 variáveis) para um conjunto menor de variáveis, que representará, sinteticamente, a intensidade dos déficits de instalações físicas, equipamentos e mobiliários de cada escola da amostra.

De acordo com a intensidade desses índices sintéticos, a classificação das unidades de ensino foi realizada distribuindo-as em três grupos. As escolas com os escores mais elevados - superiores a um desvio padrão da média positivamente ( $\mu$ $+1 \sigma)$ - foram classificadas como sendo Muito Deficitárias; as escolas com os menores escores - superiores a um desvio padrão da média, negativamente $(\mu-1 \sigma)$ - foram consideradas Pouco ou Nada Deficitárias; e as escolas com escores medianos - situados entre $-1 \sigma$ e $+1 \sigma$ - foram classificadas como Medianamente Deficitárias. O Gráfico 4 ilustra o critério para classificação das escolas. Como é possível observar, uma vez que a distribuição dos dados seja próxima da distribuição normal, a tendência é que maior parte das escolas sejam enquadradas no nível mediano.

\section{Gráfico 4: Escala para classificação das escolas quanto aos déficits de infraestrutura}

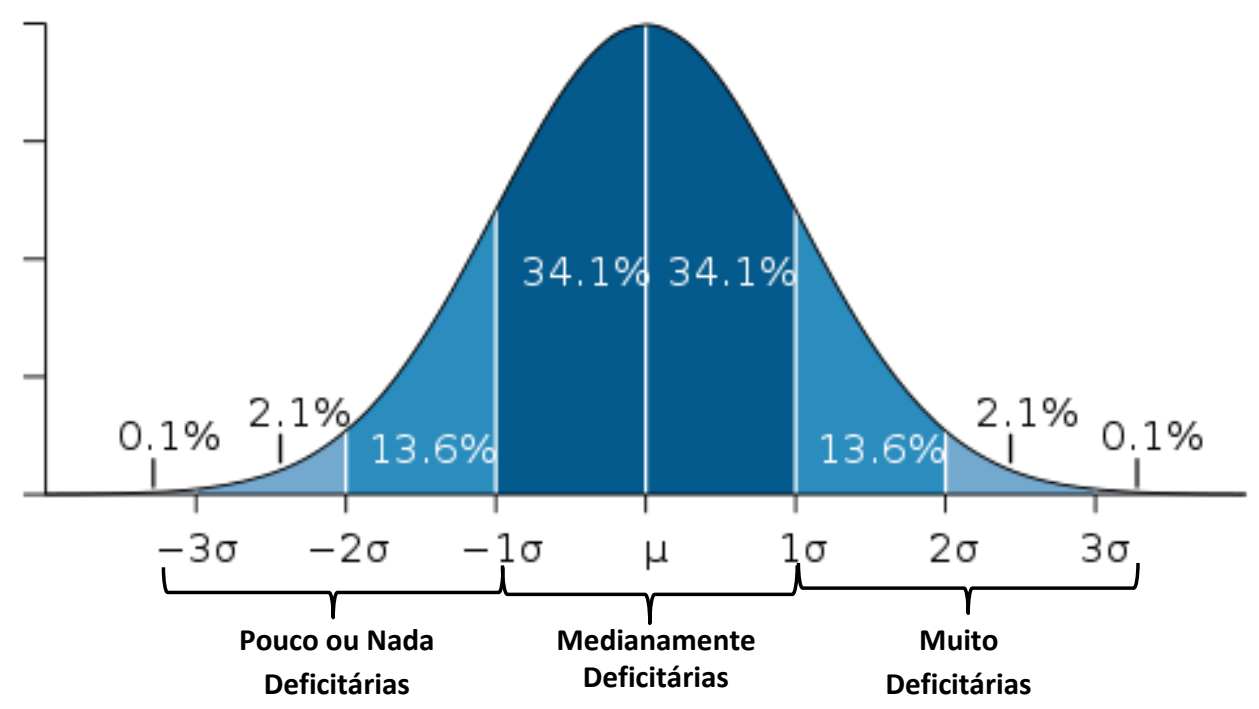




\subsection{Técnica de análise dos dados}

Para viabilizar a realização das análises implementou-se, previamente, Análise Fatorial, com vistas a sintetizar o amplo número de variáveis sobre infraestrutura (46) num conjunto mais parcimonioso de variáveis. Posteriormente, realizou-se testes de Correlação de Pearson entre as variáveis representativas dos déficits de infraestrutura e os valores transferidos às escolas, de modo a verificar se há associação entre tais dimensões e, em caso positivo, sua intensidade.

Segundo Hair (2009), a análise fatorial é uma classe de métodos estatísticos multivariados cujo propósito principal é definir a estrutura subjacente em uma matriz de dados. Segundo o autor tais métodos visam examinar os padrões ou relações latentes (chamados de fatores) para um grande número de variáveis e determinar se a informação pode ser condensada ou resumida a um conjunto menor de fatores ou componentes, com perda mínima de informação. Em outras palavras, a análise fatorial permite descrever os dados em um número muito menor de conceitos do que as variáveis originais, substituindo-as (idem). Por se tratar de uma análise multivariada, a principal vantagem é sua habilidade em acomodar múltiplas variáveis na tentativa de compreender as complexas relações não possíveis com métodos univariados ou bivariados (idem).

Conforme o autor, a análise fatorial pode ser efetivada numa perspectiva exploratória ou confirmatória. No primeiro caso - o mais comum e utilizado neste estudo - a aplicação da técnica visa identificar estrutura latente em um conjunto de variáveis ou apenas realizar a redução de variáveis. No segundo, o pesquisador tem preconcebido ideias sobre a real estrutura dos dados, baseado em suporte teórico ou em pesquisas anteriores, de modo que a análise desempenha um papel confirmatório, ou seja, de avaliação do grau em que os dados satisfazem a estrutura esperada.

De acordo com Hair (2009), para efetivação da análise fatorial passa-se por basicamente sete estágios. O primeiro refere-se à explicitação de qual o objetivo da análise, que segundo o autor, pode ser o resumo de dados ou a redução de dados. No primeiro caso, a análise visa apenas identificar a estrutura de relações entre 
variáveis ou respondentes examinando correlações entre as variáveis ou entre os respondentes. A redução de dados, por sua vez, consiste na identificação de variáveis representativas de um conjunto maior de variáveis para uso em análises subsequentes, ou na criação de um novo conjunto de variáveis, para substituir o conjunto original de variáveis, de modo a viabilizar seu uso em técnicas subsequentes (idem), justamente o propósito do uso da técnica neste estudo.

A segunda etapa para consecução da Análise Fatorial, segundo Hair (2009), consiste na seleção de variáveis e medidas. Segundo o autor que, geralmente, as variáveis para a análise devem ser métricas, isto é, dados que identificam ou descrevem indivíduos ou objetos não apenas na posse de um atributo, mas também pela quantia ou grau em que o indivíduo pode ser caracterizado pelo atributo. Outra recomendação do autor consiste em dispor de amostra com, pelo menos, cinco vezes o número de variáveis a serem observadas.

A próxima etapa a ser observada, segundo orienta Hair (2009), é a verificação das suposições estatísticas aplicáveis à Análise Fatorial. Uma suposição importante a ser observada é se há número substancial de variáveis correlacionadas entre si. Essa checagem pode ser realizada mediante inspeção visual da matriz de correlações das variáveis. Segundo Hair (2009), deve-se identificar número substancial de correlações superiores a 0,30. Outra forma de verificar o cumprimento de tal requisito, segundo o autor, é por meio da análise da matriz de correlação antiimagem, gerada pelo SPSS ${ }^{9}$. Nesta hipótese, os dados são considerados adequados para análise fatorial, se as correlações parciais forem pequenas.

Além dessas duas alternativas, o autor aponta que é possível determinar a adequação da análise fatorial mediante quantificação do grau de intercorrelações entre as variáveis, pela Medida de Adequação da Amostra (MSA). O índice varia entre 0 e 1, podendo ser interpretada da seguinte forma: 0,80 ou acima, admirável; 0,70 ou acima, mediano; 0,60 ou a cima, medíocre; 0,50 ou acima, ruim; abaixo de 0,50, inaceitável. Além da verificação geral da amostra, o autor salienta que devem ser examinados os valores de MSA para cada variável, excluindo aquelas que se encontram no domínio do inaceitável. ${ }^{10}$ Segundo Maroco (2014), é possível concluir

\footnotetext{
${ }^{9}$ Statistical Package for the Social Sciences

${ }^{10}$ Pode-se usar ainda o alfa de Cronbach, que tem nível recomendado de 0,7.
} 
que as variáveis estão correlacionadas significativamente por meio de Teste de Esfericidade de Bartlett, em que se verifique um $p$-value $<0,001$.

A quarta etapa para efetivação da Análise Fatorial, conforme Hair (2009), envolve determinar o método de extração dos fatores e o número de fatores selecionados para representar a estrutura latente dos dados. A análise de componentes apresenta-se como o método mais comumente utilizado para extração de fatores, vez que apresenta menos complicações que o outro método, a análise de fatores comuns. Além disso, segundo o autor, o modelo fatorial de componentes é apropriado "quando a preocupação principal é a previsão ou o número mínimo de fatores necessários para explicar a parte máxima da variância explicada representada no conjunto original de variáveis" (HAIR, 2009, p. 99), parecer este compartilhado por Maroco (2014). Embora se diferenciem entre si quanto aos tipos de variância considerados, segundo Hair (2009), na maioria das aplicações, ambos os métodos chegam, essencialmente, aos mesmos resultados se o número de variável exercer 30. Desse modo, optou-se pelo uso da análise de componentes no presente estudo.

Segundo Hair (2009), quatro critérios podem ser utilizados para definição do número de fatores a extrair, quais sejam, da raiz latente, em que qualquer fator individual deve explicar a variância de pelo menos uma variável; a priori, em que o pesquisado já sabe quantos fatores extrair antes de empreender a análise fatorial, casos mais comuns para testar teorias ou para repetir trabalhos de outros pesquisador; da percentagem de variância explicada, em que o objetivo é garantir significância prática para os fatores determinados, garantindo que expliquem pelo menos um montante especificado de variância - 50 \%, segundo Maroco (2014), 60 \%, segundo Hair (2009); e do teste scree, em que se analisa um gráfico das raízes latentes em relação ao número de fatores em sua ordem de extração, e se identifica o ponto onde a curva tende a ficar horizontal. Para definição do número de fatores a extrair neste estudo, optou-se por considerar, simultaneamente, mais de um critério, conforme recomendado pelo autor, avaliando-se a raiz latente, a percentagem de variância explicada e o teste scree.

O estágio que se segue é a interpretação dos fatores. Nessa etapa, Hair (2009) recomenda avaliar a pertinência de rotação dos fatores, com vistas a atingir 
um padrão fatorial mais simples e teoricamente mais significativo. Além da rotação fatorial, Hair (2009) destaca que na interpretação dos resultados há necessidade de examinar a matriz fatorial das cargas, identificar as maiores cargas para cada variável e avaliar as comunalidades das variáveis. Para exame da matriz fatorial há de se decidir quais cargas fatoriais valem a pena considerar no modelo, realizando avaliação da significância prática e estatística dos referidos escores. De acordo com o autor, diretrizes convencionais sugerem níveis de significância estatística (alfa) de 0,05 ou 0,01 . Para avaliação da significância prática, deve-se considerar que quanto maior o valor absoluto da carga fatorial, mais importante a carga na interpretação dos resultados:

(...) Em síntese, considera-se que as cargas fatoriais maiores que +0,30 atingem o nível mínimo; cargas de +-0,40 são consideradas mais importantes; e se as cargas são de $+-0,50$ ou maiores, elas são consideradas com significância prática. (HAIR, 2009, p. 107) ${ }^{11}$

Para avaliação das comunalidades, isto é, da proporção de variância explicada pela solução fatorial para cada variável, o autor indica que o pesquisador deve julgar se elas atendem a níveis de explicação aceitáveis. Como referência, o autor sugere como aceitável comunalidades de pelo menos 0,5.

A validação da análise fatorial - próximo estágio, segundo Hair (2009) consiste na avaliação do grau de generalidade e estabilidade dos resultados para a população e da influência potencial de casos individuais sobre os resultados gerais. Para tanto, o autor sugere que o método mais direto é avaliar a repetitividade dos resultados, a partir, por exemplo, de uma amostra particionada do conjunto original de dados.

A etapa final da análise consiste no cálculo dos escores fatoriais, que, na prática, constituem os índices representativos da estrutura latente extraída. Segundo Hair (2009), esses escores são "medidas compostas de cada fator para cada indivíduo", os quais podem ser utilizados em análises estatísticas posteriores. Estes escores - que, no presente estudo, representarão sinteticamente os déficits de instalações físicas, equipamentos e mobiliários - serão utilizados para realização da

\footnotetext{
${ }^{11} \mathrm{O}$ autor ressalva, porém, que esses critérios podem variar a depender do tamanho da amostra, número de variáveis analisadas e número de fatores extraídos.
} 
análise final, com vistas a verificar se há relação entre as referidas variáveis e os valores transferidos às escolas.

Como se observará na análise dos dados, foram observadas todas essas etapas para estimativa dos fatores que representarão os déficits de infraestrutura das escolas. Conforme recomendação de Machado e Barbetta (2015), optou-se pela realização de análise fatorial, separadamente, para cada categoria de infraestrutura, quais sejam, instalações físicas (que abrangem as dependências físicas do prédio escolar, envolvendo laboratórios, banheiros, refeitório, salas de aula, etc.) -, equipamentos (que envolvem o conjunto de computadores, eletroeletrônicos, eletrodomésticos, etc.) e mobiliários (abrangendo estantes, mesas, carteiras, etc.).

Conforme sugerem os autores, a alternativa visa ampliar a precisão na estimativa da estrutura latente, vez que não se mistura elementos muito heterogêneos num mesmo conjunto de dados (como quadra esportiva e aparelhos de DVD, por exemplo), contribuindo para ampliar a representatividade dos índices. Além disso, tal opção mostra-se mais pertinente para usos futuros dos índices, visto que, comumente, tais categorias de infraestrutura são financiadas por programas/ações ou rubricas orçamentárias distintas. No caso do PDDE, por exemplo, a verbas são repassadas em duas rubricas distintas, uma voltada, exclusivamente, para despesas de capital - que possibilita a aquisição de equipamentos e mobiliários - e outra destinada para despesas de custeio, que abrange manutenção, conservação e pequenos reparos nas instalações físicas das escolas.

Por fim, para verificar, empiricamente, se a proporção de recursos recebidos pelos estabelecimentos educacionais tem alguma relação com seus déficits de infraestrutura, foram realizados testes de Correlação Linear de Pearson entre os fatores estimados, representativos dos déficits de infraestrutura, e os valores transferidos. A escolha da técnica justifica-se pela suposição básica de que, se o propósito dos recursos é contribuir para que todas as escolas alcancem um padrão mínimo de qualidade de infraestrutura, e o cenário atual é de desníveis entre as escolas, alguma relação linear entre a "oferta" de recursos e os déficits ("demandas") de infraestrutura haveria de ser detectada. 
Conforme Triola (2005), o coeficiente de correlação linear de Pearson $(r)$ mede a intensidade da relação linear entre valores quantitativos de quaisquer variáveis $\mathrm{x}$ e y de uma amostra, sendo calculado da seguinte forma:

$$
r=\frac{\sum_{i=1}^{n}\left(x_{i}-\bar{x}\right)\left(y_{i}-\bar{y}\right)}{\sqrt{\sum_{i=1}^{n}\left(x_{i}-\bar{x}\right)^{2}} \sqrt{\sum_{i=1}^{n}\left(y_{i}-\bar{y}\right)^{2}}}
$$

Onde:

$r$ : coeficiente de correlação.

n:número de casos.

$\mathrm{x}_{\mathrm{i}}$ : cada um dos casos da variável $\mathrm{x}$.

$\mathrm{y}_{\mathrm{i}}$ : cada um dos casos da variável y.

$\bar{x}$ : média aritmética dos $\mathrm{n}$ casos da variável $\mathrm{x}$.

$\bar{y}_{:}$média aritmética dos $\mathrm{n}$ casos da variável y.

O valor de $r$ varia entre -1 a 1 , sendo que, quanto mais próximo destes limites, maior é a intensidade da correlação e, quanto mais próxima de zero, mais fraca pode ser considerada (LEVIN, 2004). Os sinais indicam a direção da associação entre as variáveis, podendo ser positiva, isto é, se um aumento em $X$ implicar aumento em $\mathrm{Y}$, ou, pelo contrário, negativa quando um aumento em $\mathrm{X}$ implicar redução em $Y$.

No que se refere aos pressupostos estatísticos, a adoção da técnica neste estudo cumpre todos requisitos recomendados por Filho e Júnior (2010), quais sejam: a) variáveis devem ser quantitativas (contínuas ou discretas) - neste caso, são contínuas; b) a distribuição dos valores observados deve ser normal - requisito cumprido à luz do Teorema do Limite Central ${ }^{12}$, visto que a amostra abrange número superior a 20 mil casos; c) casos atípicos devem ser verificados de modo a não afetar as correlações - requisito satisfeito, pois, mesmo com os outiliers, os

${ }^{12}$ Segundo o Teorema do Limite Central, para amostras de dimensão superior a 25-30 casos, assume-se que a distribuição da média amostral é satisfatoriamente aproximada à normal (MAROCO , 2014). 
resultados são próximos e conduzem às mesmas conclusões; e d) independência entre as observações, pressuposto também atendido, visto que os dados de uma escola são, teoricamente, independentes que os de outra unidade.

Segundo Callegari-Jacques (2003), o coeficiente de correlação pode ser avaliado qualitativamente da seguinte forma:

se $0,00<\rho^{\wedge}<0,30$, fraca correlação linear; se $0,30 \leq \rho^{\wedge}<0,60$, moderada correlação linear; se $0,60 \leq \rho^{\wedge}<0,90$, forte correlação linear; se $0,90 \leq \rho^{\wedge}<1,00$, correlação linear muito forte.

\section{ANÁLISE DOS DADOS E RESULTADOS}

\subsection{Estimativa de índices sintéticos, por meio de Análise Fatorial, para representar os déficits de infraestrutura física das escolas.}

Conforme descrito na metodologia, a classificação das escolas em termos de infraestrutura requer a síntese das diversas informações de infraestrutura, de modo a possibilitar a comparação parcimoniosa entre os estabelecimentos de ensino. Para tanto, a análise fatorial apresenta-se como estratégia metodológica compatível, visto que oferece mecanismos para construção de escalas de medida a partir da redução do número de variáveis originais.

Como se optou pela mensuração dos déficits de instalações físicas, equipamentos e mobiliários, separadamente, conforme descrito na Metodologia, foram realizadas três análises fatoriais distintas, para cada uma dessas categorias. Tal como explicado anteriormente, a estimação de escores distintos para mensurar os déficits de infraestrutura das escolas em cada uma dessas categorias pareceu mais pertinente para favorecer usos futuros da escala para orientar as políticas de financiamento educacional, haja vista que cada uma dessas categorias podem envolver programas e fontes de financiamento distintas. Assim, seguem os resultados da Análise Fatorial para cada uma das categorias consideradas. 


\subsubsection{Instalações Físicas}

Tendo sido cumpridas as etapas preparatórias da análise fatorial propostas por Hair (2009) - seleção de variáveis e medidas, e verificação do número de variáveis por amostra -, conforme apresentado na metodologia, procedeu-se à verificação dos pressupostos estatísticos de adequação do conjunto de dados para consecução da análise.

Conforme se observa na Tabela 1, do Anexo II, a inspeção visual preliminar da matriz de correlações das variáveis apontou substancial número de correlações estatisticamente significantes (49 das 55 correlações $(89,1 \%$ ), foram significantes ao nível de 0,01 ), fornecendo base adequada para prosseguir com a análise. O MSA geral da amostra - de 0,824 -, por sua vez, sugere a adequação dos dados podendo ser classificada como admirável, segundo Hair (2009). A análise da matriz antiimagem (Tabela 2, do Anexo II) também aponta para a adequação do conjunto de dados, visto que a maior parte das correlações parciais é próxima de zero (dados abaixo das diagonais), conforme recomenda Maroco (2014). O ajuste do conjunto de dados também pôde ser verificado na Medida de Adequação da Amostra (MSA) de cada variável (vide diagonal da parte inferior da tabela inferior), em que apenas uma variável teve MSA inferior a 0,5 , embora muito próximo desse valor.

Dando prosseguimento à análise, foram estimados os fatores possíveis e seu poder explicativo para seleção do número de componentes a ser mantido. Conforme a Tabela 3, do Anexo II, adotando-se o critério da raiz latente, três componentes seriam mantidas. O teste scree (Gráfico 1, do Anexo II), porém, sugere de quatro fatores. Haja vista o propósito de representação mais sintética do Déficit de Instalações Físicas das escolas optou-se pela extração inicial de três fatores, para primeira estimativa do modelo fatorial.

Ao analisar as cargas fatoriais e as comunalidades de cada variável é possível verificar o quão bem cada variável é explicada pelas componentes (HAIR, 2009). Conforme ilustrado na Tabela 4, do Anexo II, a quase totalidade das cargas fatoriais possuem significância prática ${ }^{13}$, isto é, correlações maiores que $+-0,5$. No entanto, no que se refere ao nível de comunalidade, ou seja, à quantia de variância

${ }^{13}$ Considerando o tamanho da amostra, todas as cargas fatoriais podem ser consideradas significantes estatisticamente. 
explicada pelos fatores para cada variável, é possível perceber que, para a maior parte das variáveis consideradas, a estrutura fatorial explica menos que metade da variância.

Embora não haja parâmetros taxativos na literatura pesquisada para avaliação de tais indicadores, Hair (2009) sugere a eliminação de variáveis com comunalidades muito baixas. Para o autor, a consideração para eliminação, também, deve depender da contribuição geral da variável para a pesquisa. Nesse sentido, optou-se pela reespecificarão do modelo fatorial com a retirada das variáveis Déficit de Depósito de Material de Limpeza e Déficit de Laboratório de Informática os quais apresentaram os mais baixos índices de comunalidades. Os resultados do novo modelo são apresentados nas Tabelas 1, 2, 3 e 4, do Anexo II.

Conforme apresentado na Tabela 1, do Anexo III, a nova especificação fatorial, tal como na anterior, atende a todos os requisitos estatísticos de adequação de amostra. Apesar da ligeira redução no MSA geral (agora de 0,776), o índice ainda permanece na faixa de aceitabilidade sugerida por Hair (2009), assim como os MSA individuais. De igual forma, o teste de Bartlett, aponta para adequabilidade da amostra. A Tabela 3, do Anexo III, por sua vez, indica que a retirada das duas variáveis contribuiu para que o modelo fatorial com três componentes elevasse seu poder explicativo para 50,02\%, atendendo à recomendação de Maroco (2014). Após analisar diversas soluções fatoriais, observou-se que a solução com três componentes foi a que possibilitou ajustamento mais parcimonioso dos dados, contribuindo para melhor interpretabilidade das componentes.

Considerando a matriz fatorial apresentada na Tabela 4, do Anexo III, rotacionada pelo método Varimax, nota-se ligeira elevação nas comunalidades, indicando que, no atual modelo, há maior quantia de variância explicada pelos fatores. Observa-se também que a quase totalidade das variáveis apresentaram cargas fatoriais mais elevadas em apenas um fator, o que favorece a interoperabilidade da estrutura latente.

Relativamente à interpretação da estrutura fatorial, é possível observar que as três componentes exprimem, de alguma forma, o nível de essencialidade de determinadas instalações físicas para o funcionamento dos estabelecimentos de 
ensino. Ou seja, ao passo que o terceiro fator representa carências de instalações físicas indispensáveis para o funcionamento das escolas - salas de aula -, o segundo fator reúne itens cuja existência é elementar, mas cuja carência não necessariamente inviabiliza a oferta educacional. Por exemplo, é possível que escola funcione, mesmo que o quantitativo de banheiros para os estudantes seja metade da recomendada pelos parâmetros, ou que não disponha de cozinha. A inexistência ou a existência expressivos déficits de salas de aula, por outro lado, pode inviabilizar ou comprometer severamente a oferta educativa para os estudantes. De modo análogo, o primeiro fator representa instalações físicas ainda menos essenciais, embora desejáveis a todos os estabelecimentos de ensino brasileiros, conforme sugerem os parâmetros de qualidade. Desse forma, uma possível forma de designar a estrutura latente dos dados seria: Fator 1: Déficits de Instalações Físicas Avançadas; Fator 2: Déficits de Instalações Físicas Elementares; Fator 3; Déficits de Instalações Físicas Indispensáveis.

Para validação do modelo fatorial optou-se pela repetição de todo o procedimento para dois subconjuntos extraídos da amostra original, particionados aleatoriamente. Cada subconjunto abrangeu metade da amostra original. Posteriormente, realizou-se comparação entre as matrizes fatoriais de ambos subconjuntos para, conforme sugere Hair (2009), avaliar a estabilidade da solução, mediante verificação da repetitividade da estrutura estimada no conjunto de dados original. Conforme demonstrado na Tabela 5, do Anexo III, observa-se que, nos dois subconjuntos, os resultados são análogos aos do conjunto original, em termos da estrutura latente identificada, apresentando ainda cargas fatoriais próximas das estimadas para o conjunto completo. Tais evidências demonstram estabilidade do modelo fatorial, indicando validade da estrutura estimada.

\subsubsection{Mobiliário}

Tal como para as instalações físicas, foram realizadas as etapas preparatórias da análise fatorial propostas por Hair (2009), com retorno positivo quanto à viabilidade de aplicação da técnica. No que se refere aos pressupostos estatísticos, conforme se observa na Tabela 1, do Anexo IV, a inspeção visual da matriz de correlações apontou que a quase totalidade das correlações entre as variáveis é estatisticamente significante (90 das 91 correlações). De igual forma, a 
análise da matriz de correlação anti-imagem também aponta para adequação do conjunto de dados. Conforme a Tabela 2, do Anexo III, a maior parte das correlações parciais é próxima de zero, atendendo às recomendações de Maroco (2014). ajuste do conjunto de dados também foi constatado, pelo MSA geral da amostra, que ficou em 0,888, e dos MSA individuais - todos acima de 0,8 (vide Tabela 1, do Anexo IV). Segundo a literatura, tais índices podem ser considerados admiráveis.

Na estimativa dos fatores possíveis de extração, nota-se ser possível exprimir as variáveis do conjunto de dados num número mais reduzido de componentes. Conforme demonstrado na Tabela 3, do Anexo IV, tanto o critério da raiz latente quanto da variância explicada sugerem a extração de duas componentes para a solução fatorial. O teste scree (Gráfico 1, do Anexo IV), igualmente, sugere a extração de dois fatores, tendo o ponto de inflexão na segunda componente.

Da verificação das cargas fatoriais da solução rotacionada, foi possível constatar significância prática entre a quase totalidade das variáveis do modelo e seus respectivos fatores (vide Tabela 4, do Anexo IV). Na maioria das variáveis, a estrutura fatorial com duas componentes mostrou-se satisfatória, explicando valor igual ou superior à metade da variância. Optou-se pela manutenção das variáveis com menores comunalidades, haja vista que a reespecificarão do modelo com suas retiradas não elevou substancialmente a variância total explicada. Ademais, a solução fatorial reespecificada propiciou as mesmas condições de interpretabilidade da estrutura latente.

Ao analisar a estrutura do modelo, nota-se que as duas componentes exprimem, respectivamente, mobílias usualmente instaladas nas salas de aula das escolas e mobílias relacionadas aos demais ambientes escolares (como secretaria, biblioteca/sala de leitura, sala de professores e refeitórios). Observa-se que, na primeira componente, o único item arrolado que não é típico de salas de aula estantes para biblioteca - também tem forte relação com esses ambientes, visto que, em regra, tal como o número de salas de aula, o quantitativo de livros a ser armazenado nas estantes, depende diretamente do número de alunos de uma dada escola. Dessa forma, o conjunto total de variáveis pode ser reduzido a dois fatores designados como: Fator 1 - Déficits de Mobiliários para Salas de Aula e 2 - Déficits de Mobiliários para Outros Ambientes Escolares. 
A consecução do teste de validade da solução fatorial, tal como realizado para as instalações físicas, também apontou estabilidade no modelo. Conforme é possível constatar na Tabela 5, do Anexo IV, a mesma estrutura fatorial é identificada para ambos os subconjuntos, apresentando resultados semelhantes aos obtidos com a amostra completa. A validade do modelo fatorial estimado, portanto, ficou demonstrada.

\subsubsection{Equipamentos}

Em relação ao conjunto de variáveis que representam os déficits dos equipamentos necessários ao funcionamento das escolas, também foi observado cumprimento dos requisitos preliminares para realização da análise fatorial, conforme Hair (2009). A estimativa da primeira solução fatorial foi realizada considerando 21 variáveis, cuja matriz de correlações segue apresentada na Tabela 1, do Anexo V. Conforme se pode observar desses resultados, 200 das 210 correlações $(95,2 \%)$ são estatisticamente significantes ao nível de 0,01 , patamar satisfatório para continuidade da análise. O MAS geral de 0,877 pode ser classificado com admirável, segundo Hair (2009). Também foram observados MSA individuais superiores a $0,5 \mathrm{em}$ todas as variáveis, que aponta para a viabilidade de uso da técnica (vide Tabela 2, do Anexo V).

Conforme apontado na Tabela 3 , do Anexo V, tanto o critério da raiz latente quanto $O$ da variância explicada recomendam solução fatorial com quatro componentes. A extração desse quantitativo de fatores para resumir a estrutura do conjunto de dados, também é corroborada pelo teste scree (vide Gráfico 1, do Anexo $\mathrm{V})$, visto que a partir do quarto fator a curva torna-se aproximadamente horizontal.

Ao analisar as cargas fatoriais e as comunidades para a solução rotacionada foi possível constatar diversas comunalidades relativamente baixas, algumas cargas fatoriais sem significância prática e variáveis com cargas semelhantes em mais de um fator (vide Tabela 4, do Anexo V), ocorrências que apontam para a necessidade eliminação de variáveis e reespecificarão do modelo, conforme recomenda Hair (2009) Ademais, embora já fosse possível verificar certa estrutura, principalmente, tendentes a representar os equipamentos típicos de cozinha (fator 1) e de salas de 
aula (fator 2), essa solução ainda se mostrou não parcimoniosa, visto que há variáveis relacionadas a outros ambientes escolares que mantinham níveis consideráveis de correlação com os referidos fatores. Diante disso, optou-se pela realização de sucessivas reespecificações do modelo, com a retirada de variáveis que incidiram nessas ocorrências, de modo a encontrar solução fatorial que melhor explicitasse a estrutura latente dos dados. O modelo que se demonstrou mais ajustado a esse propósito é apresentado nas Tabela 1 a 5, do Anexo VI.

Tal como no modelo inicial, a nova especificação fatorial atendeu a todos os pressupostos estatísticos preconizados por Hair (2009) e Maroco (2014), conforme demonstrado nas Tabelas 1 e 2, do Anexo VI, destacando-se a manutenção do MAS Geral em valor admirável e da quase totalidade dos MSA individuais superiores a 0,8 .

Diferentemente da primeira especificação fatorial, tal como apresentado na Tabela 3, do Anexo V, no modelo revisado os critérios de raiz latente e percentual de variância explicada, apontam para a extração de três fatores para explicar a estrutura latente. Adotando tal sugestão é possível explicar $68,17 \%$ da variância do conjunto de dados. O critério do teste scree, por sua vez, aponta para possibilidade de extração de quatro componentes (vide Gráfico 1, do Anexo VI). Haja vista o propósito de dispor de uma solução fatorial com o menor número de fatores possível, e a pequena elevação do percentual de variância que decorreria da inclusão de mais um fator, optou-se pela extração das três primeiras componentes.

Conforme é possível observar da Tabela 4, do Anexo VI, no modelo fatorial revisado identificam-se comunalidades mais elevadas que o modelo anterior. Ademais, fica mais explicita a estrutura latente, que agrega, na primeira componente, os equipamentos que, de acordo com os parâmetros adotados, devem ser assegurados às salas de aula das escolas; no segundo fator, aparelhagens típicas de cozinhas, voltadas à oferta de alimentação escolar; e no último fator equipamentos voltados às atividades administrativas das escolas. A designação proposta para os fatores é, portanto: Fator 1 - Déficits de Equipamentos para Salas de Aulas; Fator 2 - Déficits de Equipamentos para Cozinha; e Fator 3 - Déficits de Equipamentos para Atividades Administrativas. 
A consecução do teste de validade da solução fatorial, tal como realizado para as instalações físicas, também apontou estabilidade no modelo. Conforme é possível constatar na Tabela 5 , do Anexo $\mathrm{VI}$, a mesma estrutura fatorial é identificada para ambos os subconjuntos, apresentando resultados semelhantes aos obtidos com a amostra completa. A validade do modelo fatorial estimado, portanto, ficou demonstrada.

Concluída a estimativa de variáveis para descrever, sinteticamente, os déficits de infraestrutura física dos estabelecimentos de ensino - apresentadas no Quadro 6 - torna-se operacional prosseguir para a próxima etapa, a classificação das escolas, de acordo com seus déficits de infraestrutura.

Quadro 6 - Descrição dos fatores representativos dos déficits de infraestrutura física dos estabelecimentos públicos de ensino.

\begin{tabular}{|c|c|c|c|}
\hline Grupo & Fatores & Variáveis & Descrição \\
\hline \multirow{3}{*}{$\begin{array}{l}\text { Déficits de } \\
\text { Instalações Físicas }\end{array}$} & $\begin{array}{l}\text { 1. Déficits de Instalações } \\
\text { Físicas Indispensáveis }\end{array}$ & Déficits de salas de aula. & $\begin{array}{l}\text { Envolve a falta de instalações físicas } \\
\text { indispensáveis para o processo de } \\
\text { ensino-aprendizado da escola, } \\
\text { notadamente, salas de aula. }\end{array}$ \\
\hline & $\begin{array}{l}\text { 2. Déficits de Instalações } \\
\text { Físicas Elementares }\end{array}$ & $\begin{array}{l}\text { Déficits de cozinha e } \\
\text { sanitários para estudantes. }\end{array}$ & $\begin{array}{l}\text { Consiste na falta de instalações } \\
\text { físicas elementares, sem os quais as } \\
\text { escolas operariam com muita } \\
\text { dificuldade, como sanitário de } \\
\text { estudantes e cozinha. }\end{array}$ \\
\hline & $\begin{array}{l}\text { 3. Déficits de Instalações } \\
\text { Físicas Avançadas }\end{array}$ & $\begin{array}{l}\text { Déficits de salas de } \\
\text { professores, biblioteca ou sala } \\
\text { de leitura, refeitório, quadras } \\
\text { esportivas cobertas, salas de } \\
\text { TV e vídeo, e laboratório de } \\
\text { ciências. }\end{array}$ & $\begin{array}{l}\text { Abrange as carências de instalações } \\
\text { físicas mais avançadas e menos } \\
\text { comum nos estabelecimentos de } \\
\text { ensino brasileiros, tais como } \\
\text { biblioteca/sala de leitura, sala de TV } \\
\text { e vídeo, laboratório de ciências e } \\
\text { refeitório. }\end{array}$ \\
\hline \multirow{2}{*}{$\begin{array}{l}\text { Déficits de } \\
\text { Mobiliários }\end{array}$} & $\begin{array}{l}\text { 1. Déficits de Mobiliários } \\
\text { para Salas de Aula }\end{array}$ & $\begin{array}{l}\text { Déficits de cadeiras, carteiras, } \\
\text { suportes para TV e DVD, } \\
\text { quadros para sala de aula, } \\
\text { arquivos de aço, armários, } \\
\text { mesas tipo escrivaninha, } \\
\text { estantes para livros. }\end{array}$ & $\begin{array}{l}\text { Representa a falta de itens de } \\
\text { mobiliários voltados para as salas de } \\
\text { aula das escolas, tais como } \\
\text { cadeiras, carteiras, armários, mesa } \\
\text { tipo escrivaninha (para professor), } \\
\text { etc. }\end{array}$ \\
\hline & $\begin{array}{l}\text { 2. Déficits de Mobiliários } \\
\text { para Outros Ambientes } \\
\text { Escolares }\end{array}$ & $\begin{array}{l}\text { Déficits de mesas para } \\
\text { impressoras, computadores, } \\
\text { refeitório, leitura, salas dos } \\
\text { professores e armários para } \\
\text { secretaria. }\end{array}$ & $\begin{array}{l}\text { Envolve carências de mobília para } \\
\text { outros espaços escolares, que não } \\
\text { são salas de aula, tais como, mesas } \\
\text { para impressora, para } \\
\text { computadores, para refeitório, para } \\
\text { sala de professores, armários para } \\
\text { secretarias, etc. }\end{array}$ \\
\hline $\begin{array}{l}\text { Déficits de } \\
\text { Equipamentos }\end{array}$ & $\begin{array}{l}\text { 1. Déficits de } \\
\text { Equipamentos para Salas } \\
\text { de Aulas }\end{array}$ & $\begin{array}{l}\text { Déficits de Televisores, } \\
\text { Aparelhos de DVD, Aparelhos } \\
\text { de CD e rádio e Circuladores } \\
\text { de ar. }\end{array}$ & $\begin{array}{l}\text { Abrange os déficits de } \\
\text { equipamentos voltados para as } \\
\text { salas de aula das escolas, tais como } \\
\text { televisores, DVD e circuladores de } \\
\text { ar. }\end{array}$ \\
\hline
\end{tabular}




\begin{tabular}{|c|c|c|c|}
\hline & $\begin{array}{l}\text { 2.Déficits de } \\
\text { Equipamentos para } \\
\text { Cozinha }\end{array}$ & 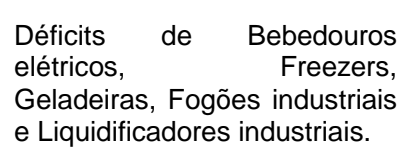 & $\begin{array}{l}\text { Consiste nas carências de } \\
\text { equipamentos para a cozinha das } \\
\text { escolas, necessários para a oferta } \\
\text { de alimentação escolar, como } \\
\text { freezers, geladeiras e fogões. }\end{array}$ \\
\hline & $\begin{array}{l}\text { 3. Déficits de } \\
\text { Equipamentos para } \\
\text { Atividades Administrativas }\end{array}$ & $\begin{array}{l}\text { Computadores para } \\
\text { administração e docente, } \\
\text { guilhotinas de papel e } \\
\text { aparelhos telefônicos. }\end{array}$ & $\begin{array}{l}\text { Representa a falta de equipamentos } \\
\text { para atividades administrativas das } \\
\text { escolas, geralmente instalados na } \\
\text { secretaria e/ou diretoria, quais sejam } \\
\text { guilhotinas de papel e aparelhos de } \\
\text { telefone. }\end{array}$ \\
\hline
\end{tabular}

Elaboração própria.

\subsection{Classificação das escolas de acordo com seus déficits de infraestrutura.}

Conforme explicitado na metodologia, a classificação das escolas quanto aos déficits de infraestrutura se efetivou, separadamente, considerando cada uma das categorias (instalações físicas, equipamentos e mobiliários). Para tanto, foi calculado, para cada escola, a média obtida para seus déficits de instalações físicas, equipamentos e mobiliários, e, de acordo com a intensidade dos déficits, atribuída uma das seguintes classificações: Muito Deficitária; Medianamente Deficitária; e Pouco ou Nada Deficitária.

Haja vista que o critério de classificação das escolas foi a posição de seus escores individuais, em relação à média da amostra, a maior parte das escolas enquadram-se no grupo Medianamente Deficitário, como esperado. Conforme demonstra a Tabela 7, dentre as categorias de infraestrutura, Equipamentos é a que possui maior proporção de escolas classificadas como Muito Deficitárias (16,6\%). Ao mesmo tempo, é a categoria com mais elevada proporção de escolas Pouco ou Nada Deficitárias (14,8\%). Tais indícios evidenciam que, dentre as categorias analisadas, há mais desigualdades entre a disponibilidade de equipamentos para as escolas, vez que eleva-se o quantitativo de escolas que ocupam os extremos da escala.

Tabela 7: Distribuição das escolas públicas de ensino fundamental do Brasil, situadas em áreas urbanas, conforme a classificação de seus déficits de instalações físicas, mobiliários e equipamentos, realizada com base em dados do Sistema PDDE Interativo, referentes a 2014.

Classificação das escolas segundo grau de infraestrutura N (\%)

$\begin{array}{clcccc}\text { Categorias } & \begin{array}{c}\text { Muito } \\ \text { deficitárias }\end{array} & \begin{array}{c}\text { Medianamente } \\ \text { deficitárias }\end{array} & \begin{array}{c}\text { Pouco ou nada } \\ \text { deficitárias }\end{array} & \begin{array}{c}\text { Casos } \\ \text { ausentes }\end{array} & \begin{array}{c}\text { Total } \\ \text { Instalações }\end{array} \\ 2.146(10,7) & 14.784(73,7) & 2.322(11,6) & 798(4,0) & 20.050(100)\end{array}$


Físicas

Mobiliários $\quad 2.683(13,4) \quad 13.956(69,6) \quad 2.587(12,9) \quad 824(4,1) \quad 20.050(100)$

*Os casos ausentes referem-se às escolas que deixaram de informar alguma informação de infraestrutura necessária para estimativa de sua correspondente classificação.

Elaboração própria.

Quando se comparam as regiões do país, tal como outros autores constataram, nota-se que as condições de infraestrutura física das escolas são substancialmente mais deficitárias nas regiões Nordeste e Norte, conforme apresentado na Tabela 8. É nessas regiões que se observa maior concentração de escolas classificadas com os mais expressivos déficits, seja em instalações físicas, mobiliários ou equipamentos. Ao passo que na região Sul, por exemplo, apenas $1,7 \%$ das escolas situam-se na faixa mais crítica, relativamente às condições das instalações físicas, no Nordeste esse percentual chega a 20,4\%, percentual 12 vezes maior que o daquela região. A região Nordeste também é a que mais concentra escolas deficitárias em equipamentos, sendo $30,5 \%$ dos estabelecimentos de ensino enquadraram-se no patamar mais insatisfatório.

Em geral, também é possível constatar, para todas as regiões do país, déficits mais expressivos de mobiliários e equipamentos, relativamente aos de instalações físicas. Mesmo nas regiões Sul e Sudeste, que apresentam os melhores índices em todos os requisitos, verifica-se déficits mais expressivos em mobiliários e equipamentos. Ao passo que apenas 1,7\% das escolas do Sul podem ser consideradas muito deficitárias em instalações físicas, quando se observam os equipamentos das escolas esse índice sobe para 3,3\%. Evidentemente, tais resultados são substancialmente mais satisfatórios que os das regiões Nordeste e Norte. Nesta última, para mesmos índices os valores correspondem a $12,4 \%$ e $22,1 \%$.

Tabela 8: Distribuição das escolas públicas de ensino fundamental urbanas, por região geográfica, conforme a classificação de seus déficits de instalações físicas, mobiliários e equipamentos, realizada com base em dados do sistema PDDE Interativo, referentes a 2014.

Classificação das escolas segundo grau de infraestrutura, por regiões geográficas $\mathrm{N}(\%)$ *

Categorias Classificação $\begin{gathered}\text { Centro Nordeste Norte Sudeste Sul } \\ \text { Oeste }\end{gathered}$

Classificação das escolas segundo grau de infraestrutura, por regiões geográficas $\mathrm{N}(\%)$ * 


\begin{tabular}{|c|c|c|c|c|c|c|}
\hline Categorias & Classificação & $\begin{array}{l}\text { Centro } \\
\text { Oeste }\end{array}$ & Nordeste & Norte & Sudeste & Sul \\
\hline \multirow{4}{*}{$\begin{array}{l}\text { Instalações } \\
\text { Físicas }\end{array}$} & Muito Deficitária & $\begin{array}{r}101 \\
(6,6)\end{array}$ & $\begin{array}{c}1.518 \\
(20,4)\end{array}$ & $\begin{array}{r}295 \\
(12,4)\end{array}$ & $\begin{array}{r}190 \\
(3,5)\end{array}$ & $\begin{array}{r}42 \\
(1,7)\end{array}$ \\
\hline & $\begin{array}{r}\text { Medianamente } \\
\text { Deficitária }\end{array}$ & $\begin{array}{l}1.324 \\
(86,6)\end{array}$ & $\begin{array}{l}5.628 \\
(75,8)\end{array}$ & $\begin{array}{l}1.920 \\
(80,7)\end{array}$ & $\begin{array}{l}4.106 \\
(74,7)\end{array}$ & $\begin{array}{l}1.806 \\
(74,5)\end{array}$ \\
\hline & $\begin{array}{r}\text { Pouco ou Nada } \\
\text { Deficitária }\end{array}$ & $\begin{array}{r}104 \\
(6,8)\end{array}$ & $\begin{array}{r}278 \\
(3,7)\end{array}$ & $\begin{array}{r}163 \\
(6,9)\end{array}$ & $\begin{array}{l}1.200 \\
(21,8)\end{array}$ & $\begin{array}{r}577 \\
(23,8)\end{array}$ \\
\hline & Total & $\begin{array}{l}1.529 \\
(100)\end{array}$ & $\begin{array}{l}7.424 \\
(100)\end{array}$ & $\begin{array}{r}2.378 \\
(100)\end{array}$ & $\begin{array}{l}5.496 \\
(100)\end{array}$ & $\begin{array}{r}2.425 \\
(100)\end{array}$ \\
\hline \multirow{4}{*}{ Mobiliários } & Muito Deficitária & $\begin{array}{r}141 \\
(9,2)\end{array}$ & $\begin{array}{l}1.531 \\
(20,7)\end{array}$ & $\begin{array}{r}489 \\
(20,6)\end{array}$ & $\begin{array}{r}433 \\
(7,9)\end{array}$ & $\begin{array}{r}89 \\
(3,7)\end{array}$ \\
\hline & $\begin{array}{r}\text { Medianamente } \\
\text { Deficitária }\end{array}$ & $\begin{array}{l}1.199 \\
(78,5)\end{array}$ & $\begin{array}{l}5.665 \\
(76,5)\end{array}$ & $\begin{array}{l}1.744 \\
(73,4)\end{array}$ & $\begin{array}{l}3.602 \\
(65,6)\end{array}$ & $\begin{array}{l}1.746 \\
(72,0)\end{array}$ \\
\hline & $\begin{array}{r}\text { Pouco ou Nada } \\
\text { Deficitária }\end{array}$ & $\begin{array}{r}188 \\
(12,3)\end{array}$ & $\begin{array}{r}213 \\
(2,9)\end{array}$ & $\begin{array}{r}142 \\
(6,0)\end{array}$ & $\begin{array}{l}1.455 \\
(26,5)\end{array}$ & $\begin{array}{r}589 \\
(24,3)\end{array}$ \\
\hline & Total & $\begin{array}{l}1.528 \\
(100)\end{array}$ & $\begin{array}{l}7.409 \\
(100)\end{array}$ & $\begin{array}{r}2.375 \\
(100)\end{array}$ & $\begin{array}{l}5.490 \\
(100)\end{array}$ & $\begin{array}{r}2.424 \\
(100)\end{array}$ \\
\hline \multirow{4}{*}{ Equipamentos } & Muito Deficitária & $\begin{array}{r}107 \\
(7,0)\end{array}$ & $\begin{array}{l}2.262 \\
(30,5)\end{array}$ & $\begin{array}{r}525 \\
(22,1)\end{array}$ & $\begin{array}{r}359 \\
(6,5)\end{array}$ & $\begin{array}{r}79 \\
(3,3)\end{array}$ \\
\hline & $\begin{array}{l}\text { Medianamente } \\
\text { Deficitária }\end{array}$ & $\begin{array}{l}1.151 \\
(75,3)\end{array}$ & $\begin{array}{l}4.829 \\
(65,2)\end{array}$ & $\begin{array}{l}1.629 \\
(68,6)\end{array}$ & $\begin{array}{l}3.679 \\
(67,0)\end{array}$ & $\begin{array}{l}1.638 \\
(67,6)\end{array}$ \\
\hline & $\begin{array}{r}\text { Pouco ou Nada } \\
\text { Deficitária }\end{array}$ & $\begin{array}{r}270 \\
(17,7)\end{array}$ & $\begin{array}{r}314 \\
(4,2)\end{array}$ & $\begin{array}{r}221 \\
(9,3)\end{array}$ & $\begin{array}{l}1.450 \\
(26,4)\end{array}$ & $\begin{array}{r}707 \\
(29,2)\end{array}$ \\
\hline & Total & $\begin{array}{l}1.528 \\
(100)\end{array}$ & $\begin{array}{l}7.405 \\
(100)\end{array}$ & $\begin{array}{l}2.375 \\
(100)\end{array}$ & $\begin{array}{l}5.488 \\
(100)\end{array}$ & $\begin{array}{r}2.424 \\
(100)\end{array}$ \\
\hline
\end{tabular}

*Todas as unidades da federação foram abrangidas.

Elaboração própria.

As desigualdades de condições de infraestrutura das escolas, porém, não se manifestam apenas entre as regiões do país. Dentre de uma mesma região é possível verificar expressivas distinções entre a disponibilidade de infraestrutura das escolas, principalmente quando se considera, separadamente, as condições das instalações físicas, mobiliários e equipamentos. Ao se analisar a situação da região Norte, por exemplo, nota-se que os déficits de equipamentos são concentrados no Amapá, Roraima e Rondônia. Ao mesmo tempo, é nestes dois últimos Estados que se observam as condições mais satisfatórias de instalações físicas e mobiliário escolar da região.

Embora seja a região com maior concentração de escolas críticas em instalações físicas, mobiliários e equipamentos, em alguns Estados da Região Nordeste verificam-se condições semelhantes aos das demais partes do país. Em termos de equipamentos, por exemplo, Alagoas, Maranhão, Paraíba, Rio Grande do Norte e Sergipe apresentam resultados similares ou até melhores que os observados em Estados das regiões Sul e Sudeste, como é o caso de Santa Catariana e Espírito Santo. 
Outra evidência que confirma achados de estudos anteriores, diz respeito às substanciais diferenças entre as condições de infraestrutura das escolas municipais, relativamente às estaduais. Como se pode verificar da Tabela 9, as redes municipais de ensino são as que mais concentram escolas em níveis críticos de instalações físicas, mobiliários e equipamentos. Enquanto apenas 4,4\% das escolas estaduais foram classificadas como Muito Deficitárias de instalações físicas, mais de $13 \%$ das municipais se enquadraram nesse grupo. Tais distinções se repetem em mobiliários e equipamentos, sendo mais crítica nesta última categoria, em que a proporção de escolas municipais na pior classificação é mais que três vezes superior à proporção de unidades escolares estaduais.

Tabela 9: Distribuição das escolas públicas de ensino fundamental urbanas, por vinculação administrativa, conforme a classificação de seus déficits de instalações físicas, mobiliários e equipamentos, realizada com base em dados do sistema PDDE Interativo, referentes a 2014.

\begin{tabular}{|c|c|c|c|}
\hline \multirow[b]{2}{*}{ Categoria } & \multirow[b]{2}{*}{ Classificação } & \multicolumn{2}{|c|}{$\begin{array}{c}\text { Classificação das escolas segundo } \\
\text { grau de infraestrutura, por vinculação } \\
\text { administrativa N (\%) }\end{array}$} \\
\hline & & Estadual & Municipal \\
\hline \multirow{4}{*}{$\begin{array}{l}\text { Instalações } \\
\text { Físicas }\end{array}$} & Muito Deficitária & $222(4,4)$ & $1.924(13,6)$ \\
\hline & Medianamente Deficitária & $4.071(79,8)$ & $10.713(75,7)$ \\
\hline & Pouco ou Nada Deficitária & $806(15,8)$ & $1.516(10,7)$ \\
\hline & Total & $5.099(100)$ & $14.153(100)$ \\
\hline \multirow{4}{*}{ Mobiliários } & Muito Deficitária & $417(8,2)$ & $2.266(16,0)$ \\
\hline & Medianamente Deficitária & $3.958(77,7)$ & $9.998(70,7)$ \\
\hline & Pouco ou Nada Deficitária & $717(14,1)$ & $1.870(13,2)$ \\
\hline & Total & $5.092(100)$ & $14.134(100)$ \\
\hline \multirow{4}{*}{ Equipamentos } & Muito Deficitária & $355(7,0)$ & $2.977(21,1)$ \\
\hline & Medianamente Deficitária & $3.859(75,8)$ & $9.067(64,2)$ \\
\hline & Pouco ou Nada Deficitária & $877(17,2)$ & $2.085(14,8)$ \\
\hline & Total & $5.091(100)$ & $14.129(100)$ \\
\hline
\end{tabular}

Elaboração própria.

Quando a análise enfoca as diferenças entre os municípios do país, nova evidências se manifestam no sentido de explicitar as diversidades de condições sobre as quais operam as escolas públicas brasileiras. O Gráfico 5, que apresenta a distribuição das escolas considerando o número de habitantes dos municípios em que se situam - indicativo do tamanho do município - deixa claro que é nos municípios pequenos onde se concentram as escolas mais deficitárias em instalações e equipamentos. À medida que as dimensões dos municípios se 
ampliam, a proporção de escolas em condições muito deficitárias de instalações físicas e equipamentos reduz.

No que se refere a mobiliários, porém, constata-se cenário um pouco diferente. Nessa categoria, a distribuição das escolas é semelhante entre os municípios, independentemente da quantidade de habitantes que possui, indicando que déficits de mobiliários não são peculiares dos municípios menores, mas também afetam as grandes cidades.

Gráfico 5: Distribuição das escolas públicas de ensino fundamental urbanas, conforme a classificação de seus déficits de instalações físicas, mobiliários e equipamentos, realizada com base em dados do sistema PDDE Interativo, referentes a 2014, entre municípios com distintos números de habitantes.

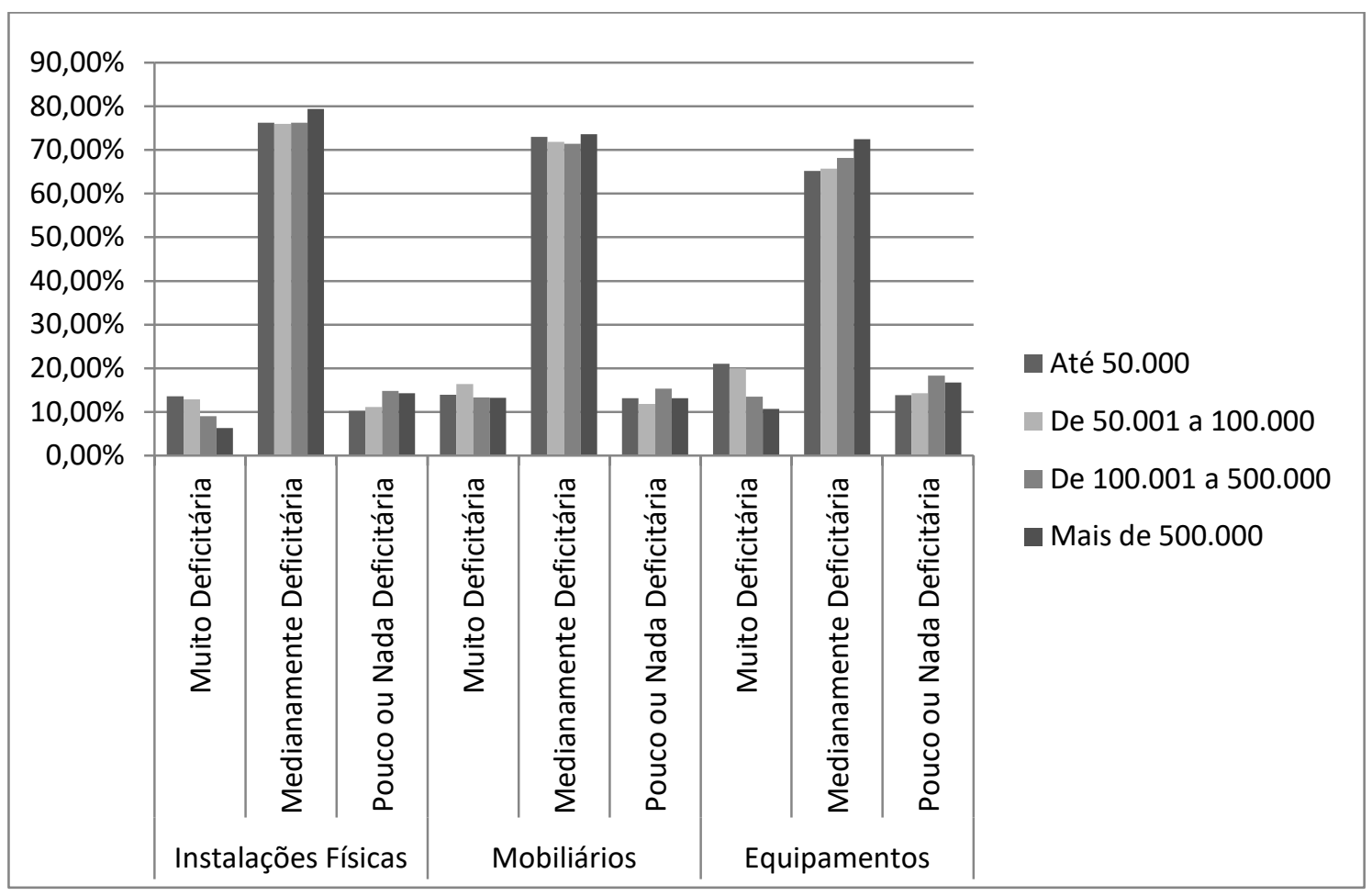

Elaboração própria.

Ao comparar as condições de infraestrutura físicas de escolas públicas situadas em municípios com diferentes Índices de Desenvolvimento Humano (IDH), novamente, observam-se severas desigualdades nas condições da oferta educacional brasileira. Como demonstra o Gráfico 6, os municípios com os piores índices de desenvolvimento são os que possuem maior proporção de escolas muito deficitárias em instalações físicas, mobiliários e equipamentos. Nesta última 
categoria, $62,3 \%$ das escolas situadas em municípios com IDH-M muito baixo estão em condições muito deficitárias.

É possível observar, que, à medida que se eleva o IDH-M, a proporção de escolas mais deficitárias reduz. Igualmente, à medida que o IDH-M se eleva, a concentração de escolas no grupo "pouco deficitário" também aumenta, indicando que municípios cuja população possui mais elevado padrão de vida - educação, longevidade e renda - contam com escolas melhor instaladas, equipadas e mobiliadas.

Gráfico 6: Distribuição das escolas públicas de ensino fundamental urbanas, conforme a classificação de seus déficits de instalações físicas, mobiliários e equipamentos, realizada com base em dados do sistema PDDE Interativo, referentes a 2014, entre municípios com distintos níveis de Índice de Desenvolvimento Humano Municipal (IDH-M)*.

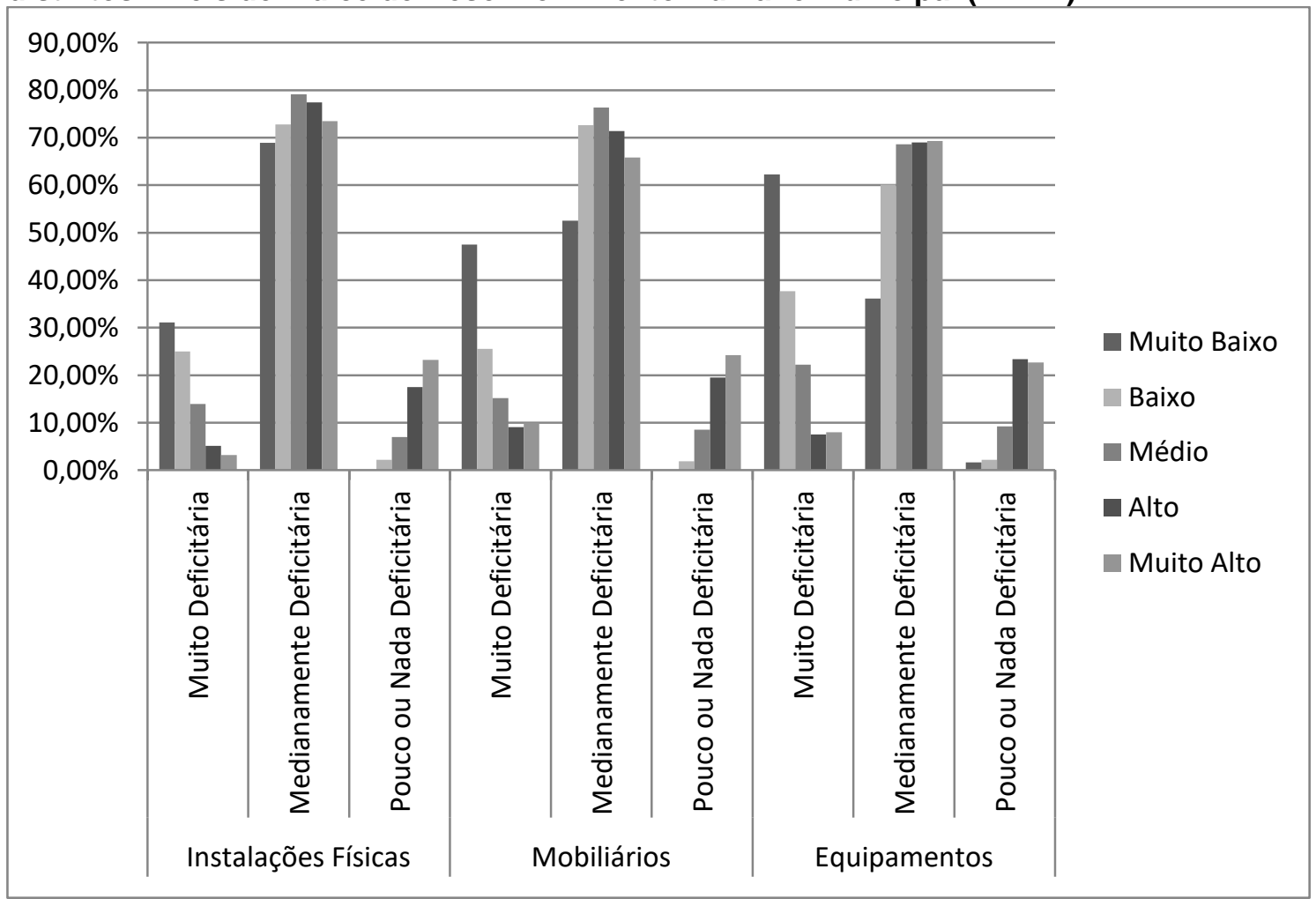

*Segundo o PNUD, o IDH-M pode ser classificado como Muito Baixo (entre 0 e 0,499); Baixo (entre 0,500 e 0,599); Médio (0,600 e 0,699); Alto (0,700 e 0,799); e Muito Alto (maior que 0,800).

Elaboração própria.

\subsection{Testes de correlação entre os valores recebidos pelas escolas e seus respectivos déficits de infraestrutura.}

Definidas as métricas para representação sintética dos déficits de infraestrutura física dos estabelecimentos de ensino, e tendo em mãos os valores 
destinados, em 2014, a cada unidade escolar pelos programas nacionais de descentralização financeira, torna-se factível verificar se a distribuição desses recursos tem sido compatível com as condições em que operam as escolas públicas do país.

Para tanto, conforme descrito na metodologia, proceder-se-á à realização de teste de correlação entre os valores transferidos às escolas e as variáveis representativas de seus déficits de infraestrutura. Haja vista que os recursos destinam-se à manutenção e melhoria da infraestrutura escolar, espera-se que alguma associação seja observada entre ambas as dimensões (financiamento e infraestrutura escolar), seja no sentido de que as escolas com maiores déficits disponham de mais recursos para melhorarem suas condições de funcionamento (associação positiva), seja no sentido de que as escolas com menor déficit (e, portanto, maior disponibilidade de infraestrutura) disponham de mais verbas para manter suas instalações, equipamentos e mobiliários (associação negativa)

A consecução dos testes de correlação deu-se em três etapas, quais sejam, entre: a) os valores per capita recebidos pelas escolas e seus déficits de infraestrutura; b) os valores per capita recebidos pelas escolas para realização de despesas de custeio (manutenção) e capital (aquisição de bens permanentes) e seus déficits de infraestrutura; e c) os valores per capita repassados por cada programa/ação às escolas e os respectivos déficits de infraestrutura.

Conforme demonstrado na Tabela 10, que apresenta as correlações de Pearson observadas entre os valores per capita recebidos pelas escolas e seus respectivos déficits de instalações físicas, mobiliários e equipamentos; embora tenham sido observadas correlações estatisticamente significativas em todos os casos (ao nível de 0,01 ou de 0,05); a intensidade dessas correlações foi inferior a | 0,3 | para todas as variáveis. De acordo Callegari-Jacques (2003), correlações dessa magnitude podem ser consideradas desprezíveis, apontando para inexistência de associação entre as variáveis.

As correlações mais expressivas foram observadas entre os valores per capita transferidos e os déficits de equipamentos para salas de aula, de equipamentos administrativos e de equipamentos para salas de aula, embora tais 
correlações ainda permaneçam na faixa desprezível. Ao verificar apenas o sinal das correlações, nota-se que há certa tendência de que as escolas mais carentes de instalações físicas avançadas e elementares, bem como de equipamentos para cozinha e para serviços administrativos, recebam menos recursos que as demais. Essa tendência, no entanto, seria muito pequena, haja vista a intensidade das correlações, podendo ser desprezada.

Tabela 10 - Correlações (Pearson) entre valores per capita recebidos pelas escolas e seus respectivos déficits de instalações físicas, mobiliários e equipamentos.

\begin{tabular}{lr}
\hline Variáveis & Valores_Per_capita \\
\hline Déficit_Inst_Avançadas &,$- 117^{* *}$ \\
Déficit_Inst_Elementares &,$- 067^{* *}$ \\
Déficit_Inst_Indispensáveis &, $054^{* *}$ \\
Déficit_Mob_Salas_Aula &, $142^{* *}$ \\
Déficit_Mob_Outros_Ambientes &,$- 107^{* *}$ \\
Déficit_Equip_Salas_Aula &, $152^{* *}$ \\
Déficit_Equip_Cozinha &,$- 016^{*}$ \\
Déficit_Equip_Administrativo &,$- 150^{* *}$ \\
\hline **. A correlação é significativa no nível 0,01 (bilateral). \\
*. A correlação é significativa no nível 0,05 (bilateral).
\end{tabular}

Tais resultados indicam que os valores per capita destinados aos estabelecimentos de ensino em 2014 não guardam qualquer relação com os déficits de infraestrutura dos estabelecimentos educacionais. Em outras palavras, a forma de distribuição dos recursos adotada pelos programas nacionais de descentralização financeira não leva em conta as distintas condições de infraestrutura das escolas do país. Assim, as escolas que receberam mais recursos não necessariamente foram as mais carentes, ou, no sentido inverso, as mais supridas de infraestrutura, visto que tais variáveis não são consideradas para distribuição das verbas.

Esses achados são, igualmente, confirmados no teste de correlação seguinte - entre os valores de custeio e capital destinados às escolas e os déficits de infraestrutura das unidades de ensino. Os dados apresentados na Tabela 11 ratificam a inexistência de qualquer associação considerável entre os valores repassados às escolas, em custeio e capital, e suas condições de infraestrutura. Segundo as normas dos programas, os recursos de custeio são destinados à aquisição de materiais para manutenção da infraestrutura dos estabelecimentos de 
ensino, enquanto os recursos de capital são voltados à aquisição de equipamentos e mobiliários.

Tabela 11 - Correlações (Pearson) entre valores per capita recebidos pelas escolas, para realização de despesas de custeio e capital, e seus respectivos déficits de instalações físicas, mobiliários e equipamentos.

\begin{tabular}{|c|c|c|}
\hline & $\begin{array}{c}\text { Valores_Per_capita_ } \\
\text { Custeio }\end{array}$ & $\begin{array}{c}\text { Valores_Per_capita_ } \\
\text { Capital }\end{array}$ \\
\hline Déficit_Inst_Avançadas &,$- 115^{\star \star}$ &,$- 094^{\star \star}$ \\
\hline Déficit_Inst_Elementares &,$- 061^{* *}$ &,$- 082^{* *}$ \\
\hline Déficit_Inst_Indispensáveis &, $040^{\star *}$ &, $113^{\star \star}$ \\
\hline Déficit_Mob_Salas_Aula &, $122^{\star *}$ & $203^{\star \star}$ \\
\hline Déficit_Mob_Outros_Ambientes &,$- 107^{\star \star}$ &,$- 075^{\star \star}$ \\
\hline Déficit_Equip_Salas_Aula &, $131^{* *}$ & $217^{\star \star}$ \\
\hline Déficit_Equip_Cozinha &,$- 019^{* *}$ & 0,007 \\
\hline Déficit_Equip_Administrativo &,$- 152^{* *}$ &,$- 096^{* *}$ \\
\hline
\end{tabular}

Por fim, resultados análogos são constatados ao verificar as correlações entre os valores per capita repassados, separadamente, por cada programa/ação de descentralização financeira, e os déficits de instalações físicas, mobiliários e equipamentos das unidades de ensino. Como indica a Tabela 12, em nenhuma dos programas foram observadas correlações consideráveis entre as dimensões de financiamento e infraestrutura. Os repasses da ação Escola Sustentável foram os que mais demonstraram descompasso com as condições de funcionamento das escolas, em que 6 , das 8 correlações, sequer alcançaram significância estatística.

Tabela 12 - Correlações (Pearson) entre valores per capita recebidos pelas escolas, repassados pelo PDDE e suas ações agregadas, e os correspondentes déficits de instalações físicas, mobiliários e equipamentos das unidades de ensino.

\begin{tabular}{|c|c|c|c|c|c|c|}
\hline & $\begin{array}{l}\text { Percapita } \\
\text { PDDE }\end{array}$ & $\begin{array}{r}\text { Percapita } \\
\text { INTEGRAL }\end{array}$ & $\begin{array}{c}\text { Percapita } \\
\text { ACESSIVEL }\end{array}$ & $\begin{array}{c}\text { Percapita } \\
\text { ATLETA }\end{array}$ & $\begin{array}{l}\text { Percapita } \\
\text { CULTURA }\end{array}$ & $\begin{array}{l}\text { Percapita } \\
\text { SUSTENT. }\end{array}$ \\
\hline Déficit_Inst_Avançadas & $-0,007$ &,$- 132^{\star *}$ & $-0,013$ &,$- 064^{* *}$ &,$- 044^{\star *}$ & 0,010 \\
\hline Déficit_Inst_Elementares &,$- 022^{* *}$ &,$- 075^{\star *}$ & $-0,010$ &,$- 017^{*}$ & $-0,002$ &, $033^{* *}$ \\
\hline Déficit_Inst_Indispensáveis &, $038^{* *}$ &, $048^{* *}$ &, $037^{\star *}$ &, $020^{* *}$ & 0,007 & $-0,007$ \\
\hline Déficit_Mob_Salas_Aula &, $061^{* *}$ &, $143^{\star \star}$ &, $031^{* *}$ &, $069^{* *}$ &, $035^{\star *}$ & 0,012 \\
\hline $\begin{array}{l}\text { Déficit_Mob_Outros_Ambien } \\
\text { tes }\end{array}$ &,$- 014^{*}$ &,$- 113^{\star \star}$ &,$- 024^{\star \star}$ &,$- 139^{* *}$ &,$- 018^{*}$ &,$- 022^{* *}$ \\
\hline Déficit_Equip_Salas_Aula &, $065^{\star *}$ &, $153^{* *}$ &, $033^{* *}$ &, $078 * *$ &, $034^{* *}$ & 0,008 \\
\hline Déficit_Equip_Cozinha & 0,005 & $-0,012$ &,$- 031^{* *}$ &,$- 108^{* *}$ &, $015^{\star}$ & 0,000 \\
\hline
\end{tabular}


**. A correlação é significativa no nível 0,01 (bilateral).

*. A correlação é significativa no nível 0,05 (bilateral).

Como se pôde observar, a análise dos dados empíricos indicam que inexiste relação linear considerável entre os valores transferidos às escolas pelos programas federais de descentralização financeira e os déficits de infraestrutura dos estabelecimentos educacionais. Tal constatação, expressa que a distribuição de recursos levada a efeito por essas políticas não tem sido condizente com o propósito de equacionar as condições de infraestrutura física das escolas, com vistas à garantia de padrão mínimo de qualidade de ensino a todos os brasileiros, visto que a proporção de recursos que cada escola recebe independe do quão deficitária esta seja em termos de instalações físicas, mobiliários e equipamentos.

A manutenção desses critérios distributivos, por conseguinte, tende a corroborar o quadro de desigualdades nas condições de infraestrutura dos estabelecimentos públicos educacionais brasileiros. À medida que a distribuição dos investimentos federais não faz distinção entre as desiguais realidades das escolas, e destina os mesmos valores para unidades de ensino situadas nos diversos pontos do "espectro" de necessidades de infraestrutura, a tendência é a perpetuação dessas desigualdades entre as escolas, dada a ausência da necessária "ação corretiva" por parte do poder público.

\section{CONSIDERAÇÕES FINAIS}

Confirmando apontamentos da literatura, as constatações do presente estudo evidenciam que as condições de infraestrutura física das escolas públicas brasileiras ainda são precárias e desiguais entre as diversas partes do país. Em que pesem as disposições constitucionais e legais que impõem ao Estado Brasileiro o provimento de serviços educacionais com padrão mínimo de qualidade e igualdade de oportunidades, o que se observa é a persistência de condições substancialmente desiguais na oferta desses serviços, notadamente quando se consideram as condições de infraestrutura dos estabelecimentos de ensino. 
A falta de instituição e adoção de referenciais normativos que clarifiquem quais sejam os padrões mínimos de infraestrutura escolar a serem assegurados a todas as escolas brasileiras, de modo compatível com seu público alvo, localização, jornada de funcionamento, entre outros, apresenta-se como um primeiro desafio para o Estado Brasileiro no sentido de equalização dessas condições de infraestrutura. Como demonstrado neste estudo, embora não oficiais, os parâmetros de infraestrutura idealizados e defendidos pela Campanha Nacional pelo Direto à Educação, bem como os padrões propostos no âmbito do programa Fundescola, são alternativas nesse sentido.

Outro passo na direção de se garantir condições mínimas para a oferta educativa com qualidade nas escolas brasileiras consiste em conceber indicadores representativos das condições de infraestrutura física das unidades de ensino que possibilitem a realização de diagnóstico da situação atual e o monitoramento de sua progressão ao longo do tempo. A mensuração dos déficits de instalações físicas, mobiliários e equipamentos das escolas, levada a efeito neste trabalho, demonstra a viabilidade de caminhar nessa direção, provendo alternativa metodológica que estima a intensidade do problema entre as diversas escolas, redes de ensino, municípios, estados e regiões. A reprodução de tal percurso com dados de outros anos, e a comparação dos resultados, poderá oferecer indícios quanto à eficácia da ação pública que visa melhorar o ambiente físico escolar.

Também ficou patente a necessidade de que o financiamento público educacional se compatibilize com as especificidades das unidades escolares do país. As evidências de que a distribuição de recursos efetivada pelos programas federais de descentralização financeira às escolas (oferta) não apresenta qualquer relação com os déficits de infraestrutura dos estabelecimentos educacionais (demanda), seguramente, indica a necessidade de revisão dos parâmetros de atendimento e financiamento dessas políticas. Evidentemente, que não apenas destas, como também de outras políticas educacionais federais, estaduais e/ou municipais voltadas à manutenção e melhoria da infraestrutura escolar.

A necessária conjugação de esforços da União e dos entes federados para modificação das, ainda, insatisfatórias realidades das escolas requer instrumentos que, antes de tudo, possibilitem o reconhecimento das especificidades e dos 
problemas do cotidiano escolar. Nesse sentido, mostra-se crucial o fortalecimento de mecanismos como o PDDE Interativo e o Censo Escolar, que proveem dados sobre o contexto das unidades de ensino.

Por fim, a investigação ora realizada corrobora a viabilidade e necessidade de estudos avaliativos em políticas públicas, os quais podem ser operacionalizados no âmbito das próprias instituições gestoras, valendo-se de dados e informações disponíveis em seus próprios repositórios institucionais.

\subsection{Recomendações}

Diante dos resultados do estudo, apresentam-se as seguintes proposições aos órgãos e entidades envolvidas com a formulação de políticas públicas educacionais, especialmente, as voltadas à manutenção e melhoria da infraestrutura dos estabelecimentos escolares:

a) aperfeiçoar os parâmetros mínimos de infraestrutura propostos pela CNDE, incluindo, entre outras, as modificações sugeridas por este trabalho e ajustes para contemplar as especificidades das escolas que ofertam mais de um nível de ensino, de modo viabilizar a adoção de tais padrões para monitoramento e avaliação da situação de infraestrutura física das escolas públicas do país;

b) aperfeiçoar e articular o sistema PDDE Interativo e o Censo Escolar, para viabilizar levantamento nacional periódico das variedades e quantidades de instalações físicas, equipamentos e mobiliários à disposição das escolas, bem como da qualidade desses itens (exemplo: metragem, condições de iluminação e ventilação das salas de aula, situação de conservação dos mobiliários, equipamentos, etc.), fornecendo dados para monitoramento e avaliação da situação de infraestrutura física das escolas públicas do país;

c) monitorar a situação de infraestrutura física das escolas públicas do país, de modo a fornecer elementos para contínua formulação, ajustamento e articulação das políticas públicas federais, estaduais e municipais - inclusive PDDE e ações agregadas -, no sentido de que a distribuição dos recursos e implementação de ações sejam compatíveis com as especificidades de infraestrutura dos 
estabelecimentos de ensino, com vistas a concorrer para a equidade de oportunidades educacionais e garantia de padrão mínimo de qualidade em todo território nacional; e

d) ajustar os critérios de alocação e distribuição de recursos do PDDE e de suas ações, considerando as distintas condições de infraestrutura das escolas beneficiárias, de modo a contribuir para a equidade de oportunidades educacionais e garantia de padrão mínimo de qualidade de infraestrutura em todas as escolas do país.

\section{REFERÊNCIAS BIBLIOGRÁFICAS}

ABRUCIO, Fernando Luiz. A coordenação federativa no Brasil. Revista de Sociologia e Política, n. 24, p. 41, 2005.

ADRIÃO, Theresa; PERONI, Vera. Implicações do Programa Dinheiro Direto na Escola para a gestão da escola pública. Educação \& Sociedade, v. 28, n. 98, p. 253-267, 2007.

AFFONSO, Rui de Britto Álvares. Descentralização e reforma do Estado: a federação brasileira na encruzilhada. Economia e Sociedade, v. 14, p. 127-152, 2000.

AFONSO, José Roberto Rodrigues; LOBO, Thereza. Descentralização fiscal e participação em experiências democráticas retardatárias. Planejamento e políticas públicas, n. 14, 2009.

ALA-HARJA, Marjukka; HELGASON, Sigurdur. Em direção às melhores práticas de avaliação. Revista do Serviço Público, Brasília, v. 51, n. 4, p. 5-59, out./dez. 2000.

ALMEIDA, Maria Hermínia Tavares de. Re-centralizing the federation?. Revista de Sociologia e Política, n. 24, p. 29-40, 2005.

O Estado no Brasil contemporâneo. Um passeio pela história. In: Melo, CR, Sáez MA, organizadores. A democracia brasileira. Balanço e perspectivas para o século XXI. Belo Horizonte: Editora UFMG; 2007. p. 17-31

ARRETCHE, Marta TS. O sistema de proteção social brasileiro: Em direção a um modelo descentralizado. São Paulo em perspectiva, v. 11, n. 3, p. 20-31, 1997.

Tendências no estudo sobre avaliação. Avaliação de políticas sociais:

uma questão em debate, v. 3, p. 29-49, 1998. 
BAÊTA, Adelaide Maria Coelho. Administração municipal e descentralização política: notas para uma discussão. Rev. adm. pública, v. 23, n. 4, p. 100-103, 1989.

BARROSO, João. O estudo da autonomia da escola: da autonomia decretada à autonomia construída. O estudo da escola. Porto: Porto Editora, p. 167-189, 1996.

BASSI, Marcos Edgar. Política educacional e descentralização: uma crítica a partir da análise da descentralização financeira dos recursos públicos enviados às escolas no Estado de Minas Gerais. San Pablo. Disert.(maest.) Faculdad de Educación da Pontifícia Universidad Catolica de San Pablo, 1996.

BRASIL. Conselho Nacional de Educação. Parecer CNE/CEB no 8/2010, aprovado em 5 de maio de 2010. Brasília, DF: 2010a. Disponível em: < http://portal.mec.gov.br/component/docman/?task=doc_download\&gid=5368\&ltemid= >. Acesso em: set. 2016.

. Constituição da república federativa do Brasil. Brasília: Senado, 1988.

Medida Provisória no 1.784, de 14 de dezembro de 1998. Dispõe sobre o repasse de recursos financeiros do Programa Nacional de Alimentação Escolar, institui o Programa Dinheiro Direto na Escola, e dá outras providências. 1998.

. Medida Provisória no 455, de 28 de janeiro de 2009. Dispõe sobre o atendimento da alimentação escolar e do Programa Dinheiro Direto na Escola aos alunos da educação básica. 2009a.

. Ministério da Administração e Rereforma do Estado. Plano Diretor da Reforma do Aparelho do Estado. Brasília, DF: MARE, 1995a.

. Ministério da Cultura. Perguntas e Respostas Frequentes do Programa Mais Cultura nas Escolas. Brasília, DF: Minc, 2014a. Disponível em: 1222/Perguntas+frequentes+Mais+Cultura+-+29122014.pdf/f38f3b1e-02e5-4e869831-6c304dbb50f0 >. Acesso em: fev. 2016.

2012a. Disponível em:

Ministério da Educação. Boletim PDE interativo. Brasília, DF: MEC, <http://pdeescola.mec.gov.br/images/stories/pdf/i\%20boletim\%20do\%20pde\%20inter ativo_direo_15mai12.pdf>. Acesso em: fev, 2016.

. Ministério da Educação. Documento Orientador do Programa Ensino Médio Inovador. Brasília, DF: MEC, 2009b. Disponível em: < http://portal.mec.gov.br/dmdocuments/documento_orientador.pdf >. Acesso em: fev. 2016.

. Ministério da Educação. Fundo Nacional de Desenvolvimento da Educação (FNDE). Conselho Deliberativo. Resolução no 12, de 10 de maio de 1995. Aprova o Manual de Procedimentos Operacionais Relativos às Transferências de Recursos Federais às Escolas das Redes Estadual e Municipal de Ensino. Brasília, DF: FNDE, 1995b. 
. Ministério da Educação. Fundo Nacional de Desenvolvimento da Educação (FNDE). Padrões mínimos de funcionamento da escola do ensino fundamental: guia de consulta. Brasília, DF: FNDE, 2006a.

. Ministério da Educação. Fundo Nacional de Desenvolvimento da Educação (FNDE). Relatório de Gestão 2006. Brasília, DF: FNDE, 2006b. Disponível em: <http://www.fnde.gov.br/index.php/inst-relatorios-degestao>. Acesso em: $11 \mathrm{fev}$. 2016.

. Ministério da Educação. Fundo Nacional de Desenvolvimento da Educação (FNDE). Conselho Deliberativo. Resolução no 27, de 14 de julho de 2006. Dispõe sobre os critérios de repasse e execução do Programa Dinheiro Direto na Escola (PDDE). Brasília, DF: FNDE, 2006c.

. Ministério da Educação. Fundo Nacional de Desenvolvimento da Educação (FNDE). Relatório de Gestão 2007. Brasília, DF: FNDE, 2007a. Disponível em: <http://www.fnde.gov.br/index.php/inst-relatorios-de-gestao>. Acesso em: fev. 2016.

. Ministério da Educação. Fundo Nacional de Desenvolvimento da Educação (FNDE). Conselho Deliberativo. Resolução no 9, de 24 de abril de 2007. Dispõe sobre os critérios de repasse e execução do Programa Dinheiro Direto na Escola (PDDE). Brasília, DF: FNDE, 2007b.

. Ministério da Educação. Fundo Nacional de Desenvolvimento da Educação $\overline{(F N D E)}$. Relatório de Gestão 2008. Brasília, DF: FNDE, 2008a. Disponível em: <http://www.fnde.gov.br/index.php/inst-relatorios-de-gestao>. Acesso em: fev. 2016.

. Ministério da Educação. Fundo Nacional de Desenvolvimento da Educação $\overline{(F N D E)}$. Conselho Deliberativo. Resolução no 19, de 21 de maio de 2008. Dispõe sobre os critérios de repasse e execução do Programa Dinheiro Direto na Escola (PDDE). Brasília, DF: FNDE, 2008b.

. Ministério da Educação. Fundo Nacional de Desenvolvimento da Educação $\overline{(F N D E)}$. Relatório de Gestão 2009. Brasília, DF: FNDE, 2009c. Disponível em: <http://www.fnde.gov.br/index.php/inst-relatorios-de-gestao>. Acesso em: fev. 2016.

. Ministério da Educação. Fundo Nacional de Desenvolvimento da Educação (FNDE). Conselho Deliberativo. Resolução no 4, de 17 de março de 2009. Dispõe sobre os critérios de repasse e execução do Programa Dinheiro Direto na Escola (PDDE). Brasília, DF: FNDE, 2009d.

. Ministério da Educação. Fundo Nacional de Desenvolvimento da Educação (FNDE). Relatório de Gestão 2010. Brasília, DF: FNDE, 2010b. Disponível em: <http://www.fnde.gov.br/index.php/inst-relatorios-de-gestao>. Acesso em: fev. 2016.

. Ministério da Educação. Fundo Nacional de Desenvolvimento da Educação (FNDE). Relatório de Gestão 2011. Brasília, DF: FNDE, 2011. Disponível em: <http://www.fnde.gov.br/index.php/inst-relatorios-de-gestao>. Acesso em: fev. 2016.

. Ministério da Educação. Fundo Nacional de Desenvolvimento da Educação $\overline{(F N D E)}$. Relatório de Gestão 2012. Brasília, DF: FNDE, 2012b. Disponível em: <http://www.fnde.gov.br/index.php/inst-relatorios-de-gestao>. Acesso em: fev. 2016. 
. Ministério da Educação. Fundo Nacional de Desenvolvimento da Educação (FNDE). Relatório de Gestão 2013. Brasília, DF: FNDE, 2013a. Disponível em: <http://www.fnde.gov.br/index.php/inst-relatorios-de-gestao>. Acesso em: fev. 2016.

. Ministério da Educação. Fundo Nacional de Desenvolvimento da Educação (FNDE). Resolução no 10, de 18 de abril de 2013. Dispõe sobre os critérios de repasse e execução do Programa Dinheiro Direto na Escola (PDDE), em cumprimento ao disposto na Lei 11.947, de 16 de junho de 2009. Brasília, DF: FNDE, 2013b.

. Ministério da Educação. Fundo Nacional de Desenvolvimento da Educação (FNDE). Conselho Deliberativo. Resolução no 32, de 2 de agosto de 2013. Dispõe sobre a destinação de recursos financeiros, nos moldes operacionais e regulamentares do Programa Dinheiro Direto na Escola (PDDE), a escolas públicas municipais, estaduais e distritais, localizadas no campo.. Brasília, DF: FNDE, 2013c.

. Ministério da Educação. Fundo Nacional de Desenvolvimento da Educação (FNDE). Conselho Deliberativo. Resolução no 33, de 9 de agosto de 2013. Dispõe sobre a destinação de recursos financeiros, nos moldes operacionais e regulamentares do Programa Dinheiro Direto na Escola (PDDE), a escolas públicas municipais, estaduais e distritais da educação básica, localizadas no campo, a fim de garantir abastecimento de água em condições apropriadas para consumo e esgotamento sanitário nas unidades escolares beneficiadas. Brasília, DF: FNDE, 2013d.

. Ministério da Educação. Fundo Nacional de Desenvolvimento da Educação $\overline{(F N D E)}$. Conselho Deliberativo. Resolução no 34, de 6 de setembro de 2013. Destinaa recursos financeiros nos moldes do Programa Dinheiro Direto na Escola (PDDE) para assegurar atividades de Educação Integral às escolas. Brasília, DF: FNDE, 2013e.

. Ministério da Educação. Fundo Nacional de Desenvolvimento da Educação (FNDE). Relatório de Gestão 2014. Brasília, DF: FNDE, 2014b. Disponível em: <http://www.fnde.gov.br/index.php/inst-relatorios-de-gestao>. Acesso em: fev. 2016.

. Ministério da Educação. Fundo Nacional de Desenvolvimento da Educação (FNDE). Boletim Informativo Dicas PDDE no 01/2016. Brasília, DF: FNDE, 2016. Disponível em: <http://www.fnde.gov.br/arquivos/category/207-boletiminformativo?download=9765:pdde-boletim-informativo-01-2016>. Acesso em: fev. 2016.

. Ministério da Educação. Guia de Orientações Operacionais do PDDE Escola do Campo. Brasília, DF: MEC, 2013f. Disponível em: < http://portal.mec.gov.br/index.php?option=com_docman\&view=download\&alias=1373 2-guia-escola-campo-2013\&category_slug=agosto-2013-pdf\&ltemid=30192>. Acesso em: fev. 2016.

. Ministério da Educação. Guia de Orientações Operacionais Adesão 2014 PDDE Água e Esgotamento Sanitário. Brasília, DF: MEC, 2014c. Disponível em: < http://pdeinterativo.mec.gov.br/arquivo/pdf/PDDE_2014_Guia_Orientacoes_agua.pdf >. Acesso em: fev. 2016. 
. Ministério da Educação. Instituir Sistema Nacional de Educação: agenda obrigatória para o país. Brasília, DF: MEC, 2015c. Disponível em:

<http://pne.mec.gov.br/images/pdf/SNE_junho_2015.pdf >. Acesso em: fev. 2016.

. Ministério da Educação. Instituto Nacional de Estudos e Pesquisas

Educacionais Anísio Teixeira. Censo Escolar. Brasília, DF: MEC, 2017a. Disponível em: < http://portal.inep.gov.br/censo-escolar>. Acesso em: fev. 2017.

. Ministério da Educação. Manual do PDDE Interativo 2013. Brasília, DF: MEC, 2013g. Disponível em:

<http://pdeinterativo.mec.gov.br/pdeinterativo2013/manuais/ManualPDEInterativo201 3.pdf>. Acesso em: fev. 2016.

. Ministério da Educação. Manual de orientação para constituição de unidades executoras. Brasília, DF, 1997.

. Ministério da Educação. Manual Operacional da Educação Integral 2014. Brasília, DF: MEC, 2014d. Disponível em: < http://portal.mec.gov.br/index.php?option=com_docman\&view=download\&alias $=1445$ 8-manual-mais-educacao-2013-final-171013-2-pdf\&category_slug=outubro-2013pdf\&ltemid=30192>. Acesso em: fev. 2016.

. Ministério da Educação. O que é PDE ESCOLA. Brasília, DF: MEC, $2015 a$. Disponível em: <http://pdeescola.mec.gov.br/index.php/o-que-e-pde-escola >. Acesso em: fev. 2016.

. Ministério da Educação. O que é PDE interativo. Brasília, DF: MEC, 2015b. Disponível em: <http://pdeescola.mec.gov.br/index.php/pde-interativo>. Acesso em: fev. 2016.

. Ministério da Educação. Secretaria de Educação Básica. Parâmetros básicos de infra-estrutura para instituições de educação infantil. Brasília : MEC, SEB, 2006c. 45 p. : il.

Lei no 9.394, de 20 de dezembro de 1996. Estabelece as diretrizes e bases da educação nacional. 1996.

. Lei no 10.172, de 9 de janeiro de 2001. Estabelece Aprova o Plano Nacional de Educação e dá outras providências. 2001.

. Lei no 11.947, de 16 de junho de 2009. Dispõe sobre o atendimento da alimentação escolar e do Programa Dinheiro Direto na Escola aos alunos da educação básica. 2009 e.

. Lei no 12.695, de 25 de julho de 2012. Inclui os polos presenciais do sistema Universidade Aberta do Brasil na assistência financeira do Programa Dinheiro Direto na Escola. 2012b.

Lei no 13.005, de 25 de junho de 2014. Aprova o Plano Nacional de Educação - PNE e dá outras providências. 2014e. 
BRESSER-PEREIRA, Luiz Carlos. Sociedade civil: sua democratização para a reforma do Estado. Sociedade e estado em transformação. São Paulo:

UNESP/ENAP, p. 67-116, 1999.

BROOKE, Nigel; SOARES, José Francisco. Pesquisa em eficácia escolar: origem e trajetórias. Editora UFMG, 2008.

CALLEGARI-JACQUES, Sidia M. Bioestatística: princípios e aplicações. Porto Alegre: Artemed, 2003. 255p.

CAMARGO, Rubens B. et al. Pesquisa nacional qualidade na educação: problematização da qualidade em pesquisa de custo aluno-ano em escolas de educação básica. Brasília, DF: INEP, 2006.

CARREIRA, Denise; PINTO, José Marcelino Rezende. Educação Pública de Qualidade: quanto custa esse direito. São Paulo: Campanha, 2010.

CARVALHO, Sonia Nahas de. Avaliação de programas sociais: balanço das experiências e contribuição para o debate. São Paulo em perspectiva, v. 17, n. 3-4, p. 185-197, 2003.

CARVALHO, Renato Gil Gomes. Cultura global e contextos locais: a escola como instituição possuidora de cultura própria. Revista Iberoamericana de Educación, v. 39, n. 2, p. 1-9, 2006.

CASTRO, Cláudio Moura; CARNOY, Martin. Como anda a reforma da educação na América Latina? Rio de Janeiro: Fundação Getúlio Vargas, 1997.

CERQUEIRA, Cezar Augusto; SAWYER, Diana Reiko Oya Tutya. Tipologia dos estabelecimentos escolares brasileiros. Revista Brasileira de Estudos

Populacionais. São Paulo: ABPE, v. 24, n. 1, 2007.

COSTA, Frederico Lustosa; CASTANHAR, José Cezar. Avaliação de programas públicos: desafios conceituais e metodológicos. RAP Rio de Janeiro, v. 37, n. 5, p. 969-992, 2003.

COTTA, Tereza Cristina. Avaliação educacional e políticas públicas: a experiência do Sistema Nacional de Avaliação da Educação Básica (SAEB). 2001.

CARREIRA, Denise; PINTO, José Marcelino Rezende. Educação pública de qualidade : quanto custa esse direito?. - 2. ed. - São Paulo : Campanha Nacional pelo Direito à Educação, 2011.

DILLINGER, W. Descentralization: politics and public services. In: AFFONSO, R. B. A., SILVA, P. L. B. A Federação em perspectiva - Ensaios selecionados. São Paulo: Fundap/Unesp, 1995. (Série Federalismo no Brasil).

DOURADO, Luiz Fernandes. Luiz Fernandes. et al. Pesquisa "A Avaliação do Plano Nacional de Educação: desafios e perspectivas”, v. 3, 2006.

DOURADO, Luiz Fernandes. Luiz Fernandes. et al. A avaliação do Plano Nacional de Educação 2001-2008, v. 1, 2 e 3, 2009. 
DOURADO, Luiz Fernandes. Políticas e gestão da educação básica no Brasil: limites e perspectivas. Educação \& Sociedade, v. 28, n. 100, p. 921-946, 2007.

DOURADO, Luiz Fernandes. OLIVEIRA, João Ferreira de; SANTOS, Catarina de Almeida. A Qualidade da Educação: Conceitos e Definições. Brasília: Instituto Nacional de Estudos e Pesquisas Educacionais Anísio Teixeira, p. 201-215, 2007.

DOURADO, Luiz Fernandes; OLIVEIRA, João Ferreira de. A qualidade da educação: perspectivas e desafios. Cadernos Cedes, Campinas, v. 29, n. 78, p. 201-215, 2009.

DOURADO, Luiz Fernandes. The National System of Education, Federalism and the obstacles to the right to basic education. Educação \& Sociedade, v. 34, n. 124, p. 761-785, 2013.

DRAIBE, Sônia Míriam. Uma nova institucionalidade das políticas sociais? Reflexões a propósito da experiência latino-americana recente de reformas dos programas sociais. São Paulo em perspectiva, v. 11, n. 4, p. 3-15, 1997.

DYE, Thomas D. Understanding Public Policy. Englewood Cliffs, N.J.: PrenticeHall. 1984.

FACHINI, Maria Ângela; OLIVEIRA, Regina Tereza Cestari. Programa Dinheiro Direto na Escola (PDDE) no contexto de redefinição do papel do Estado, Campo Grande, n. 18, p. 113-125, 2004. (Série Estudos - Periódico do Mestrado em Educação da UCDB).

FARIA, Carlos Aurélio Pimenta. Ideias, conhecimento e políticas públicas: um inventário sucinto das principais vertentes analíticas recentes. Revista Brasileira de Ciências Sociais, São Paulo, v. 18, n. 51, p. 21-30, fev. 2003.

FIGUEIREDO FILHO, Dalson Brito; JUNIOR, José Alexandre Silva. Desvendando os Mistérios do Coeficiente de Correlação de Pearson ( $r$ ). Revista Política Hoje-ISSN: 0104-7094, v. 18, n. 1, 2010.

FIORI, José Luís. O federalismo frente ao desafio da globalização. Rio de Janeiro, UERJ, Instituto de Medicina Social, 1995.

FISCHER, Tania. A gestão do município e as propostas de descentralização e participação popular. Rev. Adm. Munic, v. 34, n. 183, p. 18-35, 1987.

FONSECA, J. J. S. Metodologia da pesquisa científica. Fortaleza: UEC, 2002.

FRANCO, Creso; ALVES, Fátima; BONAMINO, Alicia. Qualidade do ensino fundamental: políticas, suas possibilidades, seus limites. Educação \& Sociedade, Campinas, vol. 28, n. 100 - Especial, p. 989-1014, out. 2007.

FRANCO, Creso et al. Qualidade e eqüidade em educação: reconsiderando o significado de" fatores intra-escolares". Revista Ensaio: Avaliação e Políticas Públicas em Educação, v. 15, n. 55, p. 277-298, 2007. 
FRANCO, Creso; SZTAJN, Paola; ORTIGÃO, Maria Isabel Ramalho. Mathematics teachers, reform, and equity: results from the Brazilian national assessment. Journal for Research in Mathematics Education, p. 393-419, 2007.

FREY, Klaus. Políticas públicas: um debate conceitual e reflexões referentes à prática da análise de políticas públicas no Brasil. Planejamento e Políticas Públicas, Brasília, n. 21, p. 211-259, jun. 2000.

FRIGOTTO, Gaudêncio; CIAVATTA, Maria. Educação básica no Brasil na década de 1990: subordinação ativa e consentida à lógica do mercado. Educação e sociedade, v. 24, n. 82, p. 93-130, 2003.

GERHARDT, Tatiana Engel; SILVEIRA, Denise Tolfo. Métodos de pesquisa. Plageder, 2009.

GIL, Antonio Carlos. Métodos e técnicas de pesquisa social. In: Métodos e técnicas de pesquisa social. Atlas, 2008.

GRACINDO, Regina Vinhaes. O Sistema Nacional de Educação e a escola pública de qualidade para todos. Retratos da Escola, v. 4, n. 6, 2012.

HAIR JR., J. F. et al. Análise multivariada de dados. 6. ed. Porto Alegre: Bookman, 2009. $688 \mathrm{p}$.

HOPPE, Robert; GRAAF, V. Henk; DIJK, V. Asje. Implementation as design problem. Problem tractability, policy theory and feasibility testing. Trabajo presentado en la reunión de IPSA sobre Policy Implmentation and Policy Evaluation. Paris, 1985.

HÖFLING, Eloísa de. Estado e políticas (públicas) sociais. Cadernos Cedes, v. 21, n. 55, p. 30-41, 2001.

HORTALE, Virginia Alonso. O conceito de descentralização aplicado aos serviços de saúde: dimensões, padrões e regularidades. Revista de Administração Pública, v. 31, n. 3, p. 23-35, 1997.

INEP. Instituto Nacional de Estudos e Pesquisas Educacionais Anísio Teixeira. Relatório Problematização da Qualidade na Pesquisa: Levantamento do custoaluno ano em escolas da Educação Básica que oferecem condições para oferta de um ensino de qualidade. Brasília, INEP, 2004.

JANNUZZI, Paulo de Martino. Indicadores para diagnóstico, monitoramento e avaliação de programas sociais no Brasil. Revista do Serviço Público, v. 56, n. 2, p. 137-160, 2014.

KRAWCZYK, Nora. A construção social das políticas educacionais no Brasil e na América Latina. $O$ cenário educacional latino-americano no limiar do século $X X \mathbf{X}$ : reformas em debate. São Paulo: Autores Associados, 2000.

KUGELMAS, Eduardo; SOLA, Lourdes. Recentralização/Descentralização: dinâmica do regime federativo no Brasil dos anos 90. Tempo social. v. 11, n. 2, p. 63-81, 1999.

LAUGLO, J. Crítica às prioridades e estratégias do Banco Mundial para a educação. Cadernos de Pesquisa, São Paulo, n. 100, p. 11-36, mar. 1997. 
LEE, V., FRANCO, C. e ALBERNAZ, A. 2004. Quality and Equality in Brazilian Secondary Schools: A Multilevel Cross-National School Effects Study. Paper presented at the 2004 Annual Meeting of the American Educational Research Association, San Diego, CA.

LEVIN, Jack; FOX, James Alan. Estatística para Ciências Humanas. 9.ed. São Paulo: Prentice - Hall, 2004.

LIMA, Leonardo Claver Amorim. Da universalização do ensino fundamental ao desafio de democratizar o ensino médio em 2016: o que evidenciam as estatísticas? Revista Brasileira de Estudos Pedagógicos, v. 92, n. 231, 2011.

LOBO, Thereza. Descentralização: conceitos, princípios, prática governamental. Cadernos de Pesquisa, n. 74, p. 5-10, 1990.

MACHADO, Denys Cristiano de Oliveira; BARBETTA, Pedro Alberto. Escala para medir o nível de aparelhamento das escolas. Reuniões da ABAVE, n. 8, p. 43-56, 2015.

MAROCO, João. Análise estatística com o SPSS Statistics. ReportNumber, 2014.

MILLS, Anne et al. Health system decentralization: concepts, issues and country experience. 1990.

MOTTA, Fernando C. Prestes. PEREIRA, Luiz Carlos Bresser. Introdução à organização burocrática. Brasiliense, 1987.

NETO, Joaquim José Soares et al. Uma escala para medir a infraestrutura escolar. Estudos em Avaliação Educacional, v. 24, n. 54, p. 78-99, 2013.

NOMA, Amélia Kimiko. História das políticas educacionais para a América Latina e o Caribe: o Projeto Principal de Educação (1980-2000). In: AZEVEDO, M. L. N.; LARA, A. M. B.. (Org.). Políticas para a educação: análises e apontamentos. Maringá: EDUEM, 2011, v. 1, p. 105-133.

NÓVOA, António. Relação escola-sociedade: novas respostas para um velho problema. Formação de professores. São Paulo: UNESP, 1998. p. 19-39.

OCDE. Programme for International Student Assessment (Pisa). 2012. Paris, 2012.

OLIVEIRA, Romualdo Portela de. Da Universalização do Ensino Fundamental ao Desafio da Qualidade: Uma Análise Histórica. Educação \& Sociedade, Campinas, vol. 28, n. 100 - Especial, p. 661-690, out. 2007.

PIERI, Renan Gomes; SANTOS, Alexandre André. Uma Proposta para o Índice de Infraestrutura Escolar e o Índice de Formação de Professores. Brasília: Inep, 2014.

PNUD. Atlas Brasil. O IDHM. 2017b. Disponível em:

<http://www.atlasbrasil.org.br/2013/pt/o_atlas/idhm/>. Acesso em: fev. 2017.

POLIT, D. F.; BECK, C. T.; HUNGLER, B. P. Fundamentos de pesquisa em enfermagem: métodos, avaliação e utilização. Trad. de Ana Thorell. 5. ed. Porto Alegre: Artmed, 2004. 
RICO, Elizabeth Melo et al. Avaliaçäo de políticas sociais: uma questäo em debate. Cortez, 1998.

RIVAS, Ricardo Hevia. Política de descentralización en la educación basica y media en América Latina: Estado del Arte. Santiago/Chile: UNESCO/REDUC, 1991.

RODDEN, Jonathan. Federalismo e descentralização em perspectiva comparada. Revista de Sociologia e Política, n. 24, p. 9, 2005.

SACRISTÁN, José Gimeno. Docencia y cultura escolar: reformas y modelo educativo. Buenos Aires: Lugar Editorial, 1997.

SANTOS, Angela Moulin S. Penalva. O desafio da gestão local em cidades de porte médio. Economia, Espaço e Sociedade no Rio de Janeiro. Rio de Janeiro: FGV, 2003.

SÁTYRO, Natália; SOARES, Sergei. A infra-estrutura das escolas brasileiras de ensino fundamental: um estudo com base nos censos escolares de 1997 a 2005. IPEA. 2007.

SCHNEIDER, Gabriela. Outro olhar no sistema de avaliação: análise de questionário e outros dados sobre infra-estrutura educacional. Revista Pedagógica, v. 12, n. 25, p. $59-83,2010$.

SOARES, José Francisco. O efeito da escola no desempenho cognitivo de seus alunos. REICE: Revista Electrónica Iberoamericana sobre Calidad, Eficacia y Cambio en Educación, v. 2, n. 2, p. 6, 2004.

SOUZA, Ângelo Ricardo. Reformas educacionais: descentralização, gestão e autonomia escolar. Educar em Revista, Curitiba, UFPR, n. 22, 2003.

SOUZA, Celina et al. Políticas públicas: uma revisão da literatura. Sociologias, v. 8 , n. 16, p. 20-45, 2006.

TIRAMONTI, Guillermina. Los imperativos de las políticas educativas de los 90. Revista da Faculdade de Educação, v. 23, n. 1-2, 1997.

TOBAR, Federico. O conceito de descentralização: usos e abusos. Planejamento e políticas públicas, v. 5, p. 31-51, 1991.

TREVISAN, Andrei Pittol; BELLEN, Hans Michael Van. Avaliação de políticas públicas: uma revisão teórica de um campo em construção. Revista de Administração Pública, v. 42, n. 3, p. 529-550, 2008.

TRIOLA, Mario F. Introdução à Estatística. Rio de Janeiro: LTC, 2005. 682p.

UNESCO. Laboratório Latinoamericano de Evaluación de la Calidade de la Educación: Primer estudio intenacional comparativo. Santiago de Chile, 1998.

Laboratório Latinoamericano de Evaluación de la Calidade de la Educación: Primer estudio intenacional comparativo, segundo informe. Santiago de Chile, 2000. 
Laboratório Latinoamericano de Evaluación de la Calidade de la Educación: Informe Técnico. Santiago de Chile, 2001.

. Proyecto Regional de Indicadores Educativos. Panorama educativo de las Ameritas: Informe Regional, Santiago de Chile, 2002.

VIANNA, Solon Magalhäes. A descentralização tutelada. Saúde debate, n. 35, p. 358, 1992.

VIANA, Ana Luiza. Abordagens metodológicas em políticas públicas. Revista de Administração Pública, v. 30, n. 2, p. 5-43, 1996.

VIANA, Ana Luiza d'Ávila et al. Descentralização e coordenação federativa: a experiência brasileira na saúde. Ciência \& Saúde Coletiva, v. 14, n. 3, p. 807-817, 2009.

VIEIRA, Paulo Reis. Em busca de uma teoria de descentralização. Revista de Administração Pública, v. 46, n. 5, p. 1409-1425, 2012.

WAISELFISZ, Jacobo. Recursos escolares fazem diferença?. Fundescola/MEC,2000a.

. Tamanho da escola, ambientes escolares e qualidade de ensino.

Fundescola/MEC, 2000b. 


\section{ANEXO I}

Parâmetros mínimos de instalações físicas, equipamentos e mobiliários para o Ensino Fundamental, com base na proposta da CNDE (2010).

Itens

\section{Instalações / dependências físicas}

Salas de Aula

Banheiros de alunos

Salas de professores

Biblioteca/Sala de leitura

Refeitório

Cozinha

Quadra coberta

Sala de depósito

Salas de TV/DVD

Laboratório de Informática

Laboratório de Ciências

\section{Mobiliários}

Carteiras

Cadeiras

Suporte para TV/DVD

Quadro para sala

Arquivo de aço

Armário

Mesa escrivaninha Nível de Ensino

\section{Fundamental Anos Iniciais}

[no de alunos em jornada parcial/25] $]^{\star 0,5+}$

[ $n^{\circ}$ de alunos em jornada integral/25] Fundamental Anos Finais

[no de alunos em jornada parcial/30] *0,5+

[ ${ }^{\circ}$ - de alunos em jornada

4
1
1
1
1
1
3
1
1
1

[no de alunos em jornada parcial ${ }^{\star} 0,5+$

[ $n^{\circ}$ de alunos em jornada integral] [no de alunos em jornada parcial] ${ }^{*} 0,5+$

[ $n^{\circ}$ de alunos em jornada integral] [1 por sala de aula] [1 por sala de aula] [1 por sala de aula] [1 por sala de aula] [1 por sala de aula]

$$
\text { integral/30] }
$$

4
1$$
\begin{array}{r}
1 \\
1
\end{array}
$$

(1)

(1)

,
[ ${ }^{\circ}$ de alunos em jornada parcial $]^{*} 0,5+$

o de alunos em jornada integral]

$$
\text { [no de alunos em jornada }
$$$$
\text { parcial] }{ }^{\star} 0,5+
$$

$n^{\circ}$ de alunos em jornada integral]

[1 por sala de aula]
[1 por sala de aula]
[1 por sala de aula]

[1 por sala de aula]

[1 por sala de aula]

(Continua) 


\begin{tabular}{|c|c|c|}
\hline \multirow{2}{*}{ Itens } & \multicolumn{2}{|c|}{ Nível de Ensino } \\
\hline & Fundamental Anos Iniciais & Fundamental Anos Finais \\
\hline Estantes para biblioteca & {$\left[n^{\circ} \text { de alunos }\right]^{*} 0,072^{14}$} & {$\left[x \text { por } n^{\circ} \text { de alunos }\right]^{\star} 0,064$} \\
\hline Mês para impressora & 2 & 4 \\
\hline Mesa para computador & 31 & 38 \\
\hline Mesas para refeitório & 1 & 2 \\
\hline Mesa de leitura & 1 & 4 \\
\hline Mesa de reunião sala de professores & 1 & 2 \\
\hline Armário para secretaria & 1 & 2 \\
\hline Equipamentos & & \\
\hline Televisor 20" & [1 por sala de aula] & [1 por sala de aula] \\
\hline Aparelho de DVD & [1 por sala de aula] & [1 por sala de aula] \\
\hline Aparelho com CD e rádio & [1 por sala de aula] & [1 por sala de aula] \\
\hline Circulador de ar de parede & [1 por sala de aula] & [1 por sala de aula] \\
\hline Computador para administração/docentes & 6 & 8 \\
\hline Computador para sala de informática & 25 & 30 \\
\hline Retroprojetor & 1 & 1 \\
\hline Tela para projeção & 1 & 1 \\
\hline Bebedouro elétrico & 2 & 4 \\
\hline Freezer 305 litros & 1 & 2 \\
\hline Geladeira 270 litros & 1 & 2 \\
\hline Fogão industrial & 1 & 2 \\
\hline Liquidificador industrial & 1 & 2 \\
\hline Botijão de gás 13 quilos & 1 & 2 \\
\hline Máquina fotográfica & 1 & 1 \\
\hline Impressora laser & 1 & 2 \\
\hline Impressora jato de tinta & 1 & 2 \\
\hline
\end{tabular}

(Continua) ${ }_{14}$ Coeficiente calculado a partir do número de livros e estantes para biblioteca recomendados pelos parâmetros do CNDE. Considerou-se uma média de 18 livros por aluno,
para os anos iniciais do ensino fundamental, e 16 livros por alunos, para os anos finais. Considerando esse números e as recomendações do CNDE, concluiu-se que as
estantes comportariam em média 250 livros. A razão entre o número de livros de aluno e a quantidade de livros por estante é o coeficiente. 


\begin{tabular}{lcrr} 
& Itens & \multicolumn{2}{c}{ Nível de Ensino } \\
& Fundamental Anos Iniciais & Fundamental Anos Finais \\
\hline Fotocopiadora & 1 & 1 \\
Guilhotina para papel & & 1 & 1 \\
Máquina de lavar & 1 & 1 \\
Telefone & 1 & 2 \\
\hline
\end{tabular}

Fonte: Campanha Nacional pelo Direito à Educação. 2010. Com ajustes do autor.

Elaboração própria. 


\section{ANEXO II}

Resultados da Análise Fatorial para Déficits de Instalações Físicas - 1 Modelo

Tabela 1 - Matriz de Correlações, Medida de Adequação da Amostra (MSA) e Teste Bartlett para as variáveis indicativas dos déficits de Instalações Físicas das escolas.

\begin{tabular}{|c|c|c|c|c|c|c|c|c|c|c|c|c|}
\hline \multirow{2}{*}{\multicolumn{2}{|c|}{ Variável }} & \multicolumn{11}{|c|}{ Correlação entre variáveis } \\
\hline & & $\mathrm{X} 1$ & $\mathrm{X} 2$ & X3 & X4 & $\times 5$ & $\mathrm{X} 6$ & X7 & $\mathrm{X} 8$ & X9 & $\mathrm{X} 10$ & $\mathrm{X} 11$ \\
\hline $\mathrm{X} 1$ & Déficit_Inst_Saladeaula & 1,00 & & & & & & & & & & \\
\hline $\mathrm{X} 2$ & Déficit_Inst_Sanitáriodosestudantes & 0,01 & 1,00 & & & & & & & & & \\
\hline X3 & Déficit_Inst_Saladeprofessores & $-0,01$ & $0,17^{*}$ & 1,00 & & & & & & & & \\
\hline $\mathrm{X} 4$ & Déficit Inst BibliotecaouSaladeleitura & 0,01 & $0,16^{*}$ & $0,38^{*}$ & 1,00 & & & & & & & \\
\hline X5 & Déficit Inst Refeitório & $0,04^{*}$ & $0,09^{*}$ & $0,29^{*}$ & $0,27^{*}$ & 1,00 & & & & & & \\
\hline X6 & Déficit_Inst_Cozinha & $0,09^{*}$ & $0,15^{\star}$ & $0,15^{\star}$ & $0,14^{*}$ & $0,10^{*}$ & 1,00 & & & & & \\
\hline $\mathrm{X} 7$ & Déficit_Inst_Quadradeesportescoberta & $-0,04^{*}$ & $0,10^{*}$ & $0,29^{*}$ & $0,25^{\star}$ & $0,31^{*}$ & $0,07^{*}$ & 1,00 & & & & \\
\hline X8 & Déficit_Inst_Depósitodematerialdelimpeza & 0,00 & $0,12^{*}$ & $0,24^{*}$ & $0,23^{*}$ & $0,22^{*}$ & $0,11^{*}$ & $0,18^{*}$ & 1,00 & & & \\
\hline X9 & Déficit Inst SaladeTVevídeo & $0,03^{*}$ & $0,08^{*}$ & $0,21^{*}$ & $0,25^{*}$ & $0,23^{*}$ & $0,05^{*}$ & $0,21^{*}$ & $0,18^{*}$ & 1,00 & & \\
\hline $\mathrm{X} 10$ & Déficit_Inst_Laboratóriodeinformática & $-0,01$ & $0,13^{*}$ & $0,25^{*}$ & $0,30^{*}$ & $0,18^{*}$ & $0,14^{*}$ & $0,20^{*}$ & $0,17^{*}$ & $0,14^{*}$ & 1,00 & \\
\hline $\mathrm{X} 11$ & Déficit_Inst_Laboratóriodeciências & 0,00 & $0,07^{\star}$ & $0,16^{\star}$ & $0,18^{*}$ & $0,20^{*}$ & $0,03^{*}$ & $0,24^{*}$ & $0,13^{*}$ & $0,22^{*}$ & $0,14^{*}$ & 1,00 \\
\hline
\end{tabular}

Medida Geral da Adequação da Amostra: 0,824

Teste Bartlett de Esfericidade: 20.238 Significância: 0,0000

*Indica as correlações significantes ao nível de 0,01. 
Tabela 2 - Matriz Anti-Imagem para as Covariâncias e Correlações Parciais entre as variáveis relativas aos déficits de Instalações Físicas das escolas.

\begin{tabular}{|c|c|c|c|c|c|c|c|c|c|c|c|c|c|}
\hline & & \multirow{2}{*}{ Variável } & \multicolumn{11}{|c|}{ Medidas de adequação da amostra e correlações parciais } \\
\hline & & & $\mathrm{X} 1$ & $\mathrm{x} 2$ & X3 & $\mathrm{X} 4$ & X5 & $\mathrm{X} 6$ & X7 & $\mathrm{X} 8$ & X9 & $\mathrm{X} 10$ & $\mathrm{X} 11$ \\
\hline \multirow{22}{*}{ Covariâncias } & $\mathrm{X} 1$ & Déficit Inst Saladeaula & ,985 & & & & & & & & & & \\
\hline & $\mathrm{x} 2$ & Déficit Inst Sanitáriodosestudantes & 000 &, 937 & & & & & & & & & \\
\hline & X3 & Déficit Inst Saladeprofessores & ,023 &,- 070 &, 756 & & & & & & & & \\
\hline & $\mathrm{X} 4$ & Déficit_Inst_BibliotecaouSaladeleitura &,- 001 &,- 056 &,- 171 &, 755 & & & & & & & \\
\hline & $\mathrm{X} 5$ & Déficit_Inst_Refeitório &,- 044 &, 002 &,- 103 &,- 073 & ,804 & & & & & & \\
\hline & $\mathrm{X} 6$ & Déficit_Inst_Cozinha &,- 091 &,- 105 &,- 059 &,- 040 &,- 021 & ,935 & & & & & \\
\hline & $\mathrm{X} 7$ & Déficit_Inst_Quadradeesportescoberta & ,043 &,- 018 &,- 105 &,- 055 &,- 151 & ,002 & 811 & & & & \\
\hline & $\mathrm{x} 8$ & Déficit Inst Depósitodematerialdelimpeza & 010 &,- 046 &,- 077 &,- 070 &,- 087 &,- 050 &,- 039 & ,883 & & & \\
\hline & X9 & Déficit_Inst_SaladeTVevídeo &,- 031 &,- 008 &,- 052 &,- 093 &,- 087 & ,012 &,- 059 &,- 066 & ,865 & & \\
\hline & $\mathrm{X} 10$ & Déficit_Inst_Laboratóriodeinformática & ,014 &,- 047 &,- 080 &,- 141 &,- 026 &,- 071 &,- 063 &,- 049 &,- 021 & ,859 & \\
\hline & $\mathrm{X} 11$ & Déficit Inst Laboratóriodeciências &, 004 &,- 017 &,- 013 &,- 038 &,- 073 & 018 &,- 118 &,- 030 &,- 125 &,- 040 & ,892 \\
\hline & $\mathrm{X} 1$ & Déficit Inst Saladeaula & ,449a & & & & & & & & & & \\
\hline & $\mathrm{X} 2$ & Déficit_Inst_Sanitáriodosestudantes &, 000 & ,826a & & & & & & & & & \\
\hline & X3 & Déficit_Inst_Saladeprofessores & ,026 &,- 083 &, $820 a$ & & & & & & & & \\
\hline & $\mathrm{X} 4$ & Déficit_Inst_BibliotecaouSaladeleitura &,- 001 &,- 067 &,- 226 & ,817a & & & & & & & \\
\hline & $\mathrm{x} 5$ & Déficit_Inst_Refeitório &,- 049 & ,003 &,- 132 &,- 094 & ,828a & & & & & & \\
\hline & $\mathrm{X} 6$ & Déficit_Inst_Cozinha &,- 095 &,- 112 &,- 071 &,- 048 &,- 025 & ,761a & & & & & \\
\hline & $\mathrm{X} 7$ & Déficit_Inst_Quadradeesportescoberta & ,048 &,- 021 &,- 134 &,- 070 &,- 187 &, 002 & ,824a & & & & \\
\hline & $\mathrm{x} 8$ & Déficit_Inst_Depósitodematerialdelimpeza & 010 &,- 050 &,- 094 &,- 086 &,- 103 &,- 055 &,- 046 & ,868a & & & \\
\hline & X9 & Déficit_Inst_SaladeTVevídeo &,- 034 &,- 009 &,- 064 &,- 115 &,- 104 &, 013 &,- 070 &,- 076 & ,838a & & \\
\hline & $\mathrm{X} 10$ & Déficit Inst Laboratóriodeinformática & 015 &,- 052 &,- 099 &,- 175 &,- 031 &,- 079 &,- 075 &,- 056 &,- 025 & ,842a & \\
\hline & $\mathrm{X} 11$ & Déficit_Inst_Laboratóriodeciências & ,004 &,- 018 &,- 016 &,- 046 &,- 086 & ,020 &,- 138 &,- 034 &,- 142 &,- 046 & ,822a \\
\hline
\end{tabular}


Tabela 3 - Autovalores e variância explicada pelos fatores componentes identificados referentes aos Déficits de Instalações Físicas das escolas.

\begin{tabular}{cccc}
\hline Componente & Autovalores & $\begin{array}{c}\text { \% de variância } \\
\text { explicada }\end{array}$ & $\begin{array}{c}\text { \% cumulativo de variância } \\
\text { explicada }\end{array}$ \\
\hline $\mathbf{1}$ & $\mathbf{2 , 7 1 5}$ & $\mathbf{2 4 , 6 8}$ & $\mathbf{2 4 , 6 8}$ \\
$\mathbf{2}$ & $\mathbf{1 , 1 4 6}$ & $\mathbf{1 0 , 4 1}$ & $\mathbf{3 5 , 0 9}$ \\
$\mathbf{3}$ & $\mathbf{1 , 0 2 6}$ & $\mathbf{9 , 3 3}$ & $\mathbf{4 4 , 4 2}$ \\
$\mathbf{4}$ & 0,884 & 8,03 & 52,46 \\
5 & 0,851 & 7,73 & 60,19 \\
6 & 0,824 & 7,49 & 67,68 \\
7 & 0,813 & 7,39 & 75,07 \\
8 & 0,774 & 7,04 & 82,10 \\
9 & 0,699 & 6,35 & 88,46 \\
10 & 0,665 & 6,05 & 94,51 \\
11 & 0,604 & 5,49 & 100,00 \\
\hline
\end{tabular}

Gráfico 1 - Teste scree para análise das componentes referentes aos Déficits de Instalações Físicas das escolas.

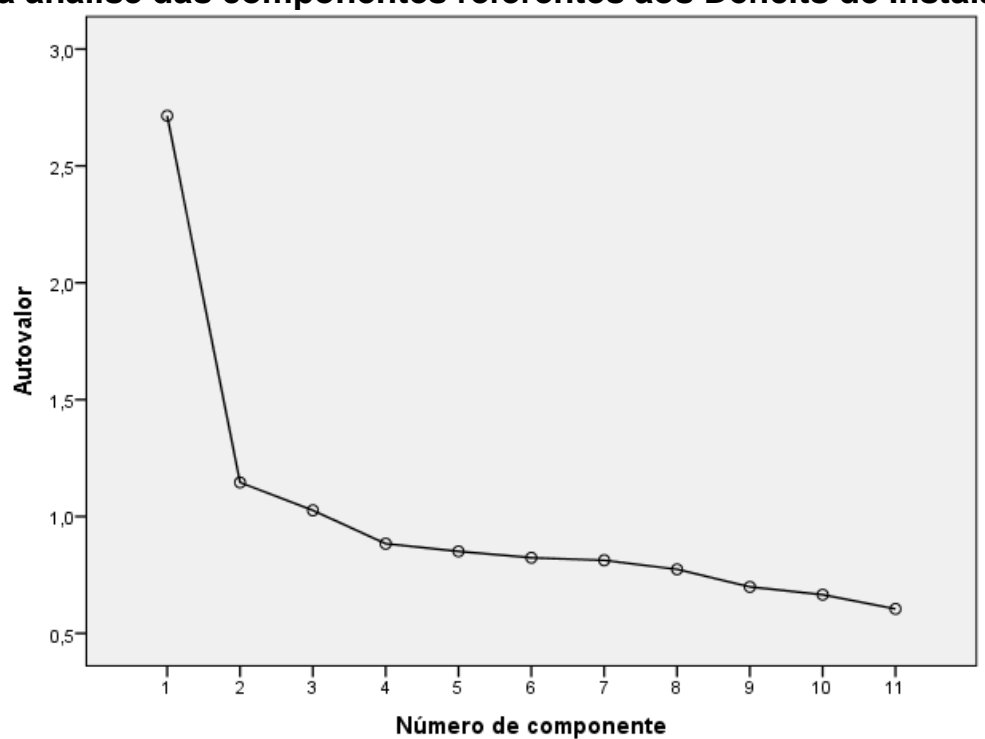


Tabela 4 - Matriz fatorial rotacionada das componentes extraídas referentes aos Déficits de Instalações Físicas das escolas.

\begin{tabular}{lcccc}
\hline \multirow{2}{*}{ Variáveis } & \multicolumn{3}{c}{ Componentes } & \multirow{2}{*}{ Comunalidade } \\
\cline { 2 - 5 } & \multicolumn{1}{c}{1} & $\mathbf{2}$ & $\mathbf{3}$ & \\
\hline Déficit_Inst_Saladeaula & 0,079 & $-0,053$ & 0,920 & 0,855 \\
Déficit_Inst_Sanitáriodosestudantes & $-0,075$ & 0,620 & 0,001 & 0,390 \\
Déficit_Inst_Saladeprofessores & 0,417 & 0,521 & $-0,094$ & 0,454 \\
Déficit_Inst_BibliotecaouSaladeleitura & 0,430 & 0,506 & $-0,059$ & 0,444 \\
Déficit_Inst_Refeitório & 0,618 & 0,188 & 0,082 & 0,423 \\
Déficit_Inst_Cozinha & $-0,108$ & 0,602 & 0,387 & 0,523 \\
DéficitInst_Quadradeesportescoberta & 0,595 & 0,191 & $-0,150$ & 0,413 \\
Déficit_Inst_Depósitodematerialdelimpeza & $\mathbf{0 , 3 4 0}$ & $\mathbf{0 , 3 6 6}$ & $\mathbf{- 0 , 0 0 9}$ & $\mathbf{0 , 2 5 0}$ \\
Déficit_Inst_SaladeTVevídeo & $\mathbf{0 , 6 2 1}$ & 0,041 & 0,106 & 0,399 \\
Déficit_Inst_Laboratóriodeinformática & $\mathbf{0 , 2 3 8}$ & $\mathbf{0 , 5 2 5}$ & $\mathbf{- 0 , 1 1 0}$ & $\mathbf{0 , 3 4 4}$ \\
Déficit_Inst_Laboratóriodeciências & $\mathbf{0 , 6 2 2}$ & $-0,059$ & $-0,008$ & $\mathbf{0 , 3 9 0}$ \\
\hline
\end{tabular}


ANEXO III

Resultados da Análise Fatorial para Déficits de Instalações Físicas - Modelo Final

Tabela 1 - Matriz de Correlações, Medida de Adequação da Amostra (MSA) e Teste Bartlett para as variáveis indicativas dos déficits de Instalações Físicas das escolas (Modelo Final).

\begin{tabular}{|c|c|c|c|c|c|c|c|c|c|c|}
\hline & \multirow{2}{*}{ Variável } & \multicolumn{9}{|c|}{ Correlação entre variáveis } \\
\hline & & $\mathrm{X} 1$ & $\mathrm{X} 2$ & X3 & $\times 4$ & $\times 5$ & 6 & X7 & $\mathrm{X} 8$ & X9 \\
\hline $\mathrm{X} 1$ & Déficit Inst Saladeaula & 1,00 & & & & & & & & \\
\hline $\mathrm{X} 2$ & Déficit_Inst_Sanitáriodosestudantes & 0,01 & 1,00 & & & & & & & \\
\hline X3 & Déficit Inst Saladeprofessores & $-0,01$ & $0,17^{*}$ & 1,00 & & & & & & \\
\hline X4 & Déficit Inst BibliotecaouSaladeleitura & 0,01 & $0,16^{*}$ & $0,38^{*}$ & 1,00 & & & & & \\
\hline X5 & Déficit Inst Refeitório & $0,04^{*}$ & $0,09^{*}$ & $0,29^{*}$ & $0,27^{*}$ & 1,00 & & & & \\
\hline X6 & Déficit_Inst_Cozinha & $0,09^{*}$ & $0,15^{\star}$ & $0,15^{\star}$ & $0,14^{*}$ & $0,10^{*}$ & 1,00 & & & \\
\hline $\mathrm{X} 7$ & Déficit_Inst_Quadradeesportescoberta & $-0,04^{*}$ & $0,10^{*}$ & $0,29^{*}$ & $0,25^{\star}$ & $0,31^{*}$ & $0,07^{*}$ & 1,00 & & \\
\hline $\mathrm{X} 8$ & Déficit_Inst_SaladeTVevídeo & $0,03^{\star}$ & $0,08^{*}$ & $0,21^{*}$ & $0,25^{\star}$ & $0,23^{*}$ & $0,05^{\star}$ & $0,21^{*}$ & 1,00 & \\
\hline X9 & Déficit_Inst_Laboratóriodeciências & 0,00 & $0,07^{*}$ & $0,16^{*}$ & $0,18^{*}$ & $0,20^{*}$ & $0,03^{*}$ & $0,24^{*}$ & $0,22^{*}$ & 1,00 \\
\hline \multicolumn{11}{|c|}{ Medida Geral da Adequação da Amostra: 0,776 } \\
\hline
\end{tabular}


Tabela 2 - Matriz Anti-Imagem para as Covariâncias e Correlações Parciais entre as variáveis relativas aos déficits de Instalações Físicas das escolas (Modelo Final).

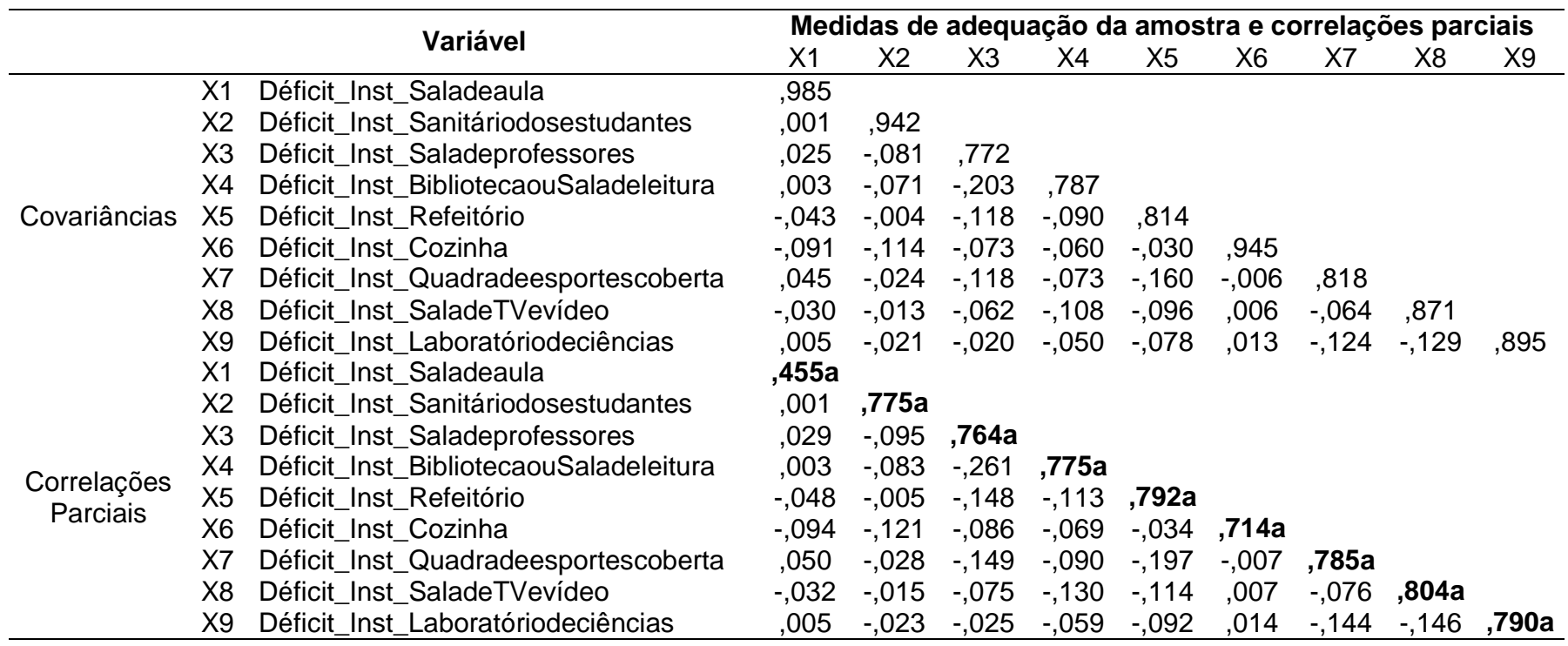

Tabela 3 - Autovalores e variância explicada pelos fatores componentes identificados referentes aos Déficits de Instalações Físicas das escolas (Modelo Final).

\begin{tabular}{cccc}
\hline Componente & Autovalores & $\begin{array}{c}\text { \% de variância } \\
\text { explicada }\end{array}$ & $\begin{array}{c}\text { \% cumulativo de } \\
\text { variância explicada }\end{array}$ \\
\hline $\mathbf{1}$ & $\mathbf{2 , 3 5 4}$ & $\mathbf{2 6 , 1 6}$ & $\mathbf{2 6 , 1 6}$ \\
$\mathbf{2}$ & $\mathbf{1 , 1 3 6}$ & $\mathbf{1 2 , 6 3}$ & $\mathbf{3 8 , 7 8}$ \\
$\mathbf{3}$ & $\mathbf{1 , 0 1 2}$ & $\mathbf{1 1 , 2 4}$ & $\mathbf{5 0 , 0 2}$ \\
$\mathbf{4}$ & 0,871 & 9,68 & 59,70 \\
5 & 0,821 & 9,12 & 68,82 \\
6 & 0,798 & 8,87 & 77,69 \\
7 & 0,727 & 8,08 & 85,77 \\
8 & 0,670 & 7,45 & 93,22 \\
9 & 0,610 & 6,78 & 100,00 \\
\hline
\end{tabular}


Gráfico 1 - Teste scree para análise das componentes referentes aos Déficits de Instalações Físicas das escolas (Modelo Final).

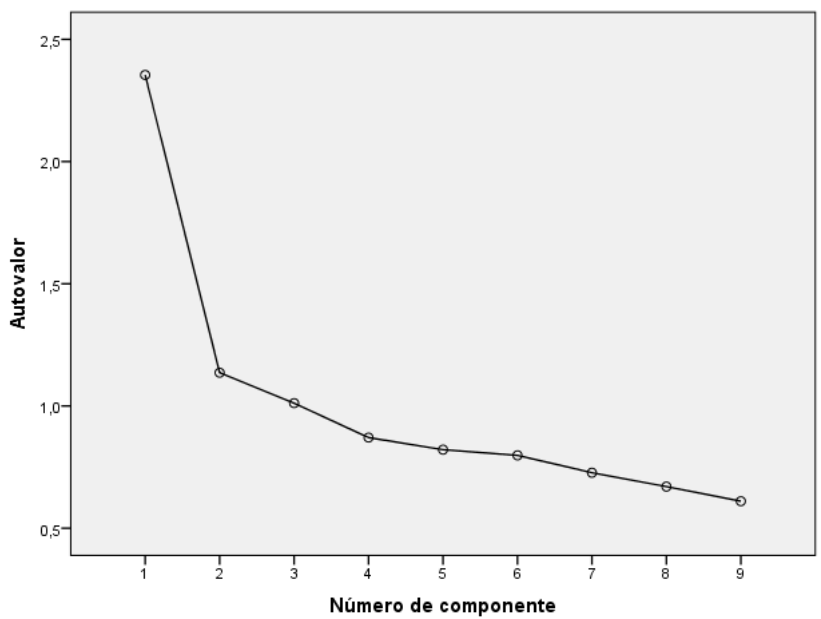

Tabela 4 - Matriz fatorial rotacionada pelo método Varimax e comunalidades referentes aos Déficits de Instalações Físicas das escolas (Modelo Final).

\begin{tabular}{lcccc}
\hline \multicolumn{1}{c}{ Variáveis } & \multicolumn{3}{c}{ Componentes } & Comunalidade \\
\hline Déficit_Inst_Saladeaula & 1 & $\mathbf{2}$ & 3 & (In) \\
Déficit_Inst_Sanitáriodosestudantes & 0,037 & 0,017 & $\mathbf{0 , 9 3 3}$ & 0,873 \\
Déficit_Inst_Saladeprofessores & 0,016 & $\mathbf{0 , 6 9 6}$ & $-0,115$ & 0,498 \\
Déficit_Inst_BibliotecaouSaladeleitura & $\mathbf{0 , 5 0 6}$ & 0,466 & $-0,128$ & 0,489 \\
Déficit_Inst_Refeitório & $\mathbf{0 , 5 1 8}$ & 0,418 & $-0,068$ & 0,448 \\
Déficit_Inst_Cozinha & $\mathbf{0 , 6 3 7}$ & 0,135 & 0,078 & 0,431 \\
Déficit_Inst_Quadradeesportescoberta & $-0,025$ & $\mathbf{0 , 6 7 2}$ & 0,309 & 0,547 \\
Déficit_Inst_SaladeTVevídeo & $\mathbf{0 , 6 3 0}$ & 0,118 & $-0,152$ & 0,434 \\
Déficit_Inst_Laboratóriodeciências & $\mathbf{0 , 6 1 7}$ & $-0,018$ & 0,121 & 0,396 \\
\hline
\end{tabular}


Tabela 5 - Matriz fatorial rotacionada dos dois subconjuntos utilizados para validação do modelo fatorial referente aos Déficits de Instalações Físicas das escolas (Modelo Final).

\begin{tabular}{lcccccc}
\hline & \multicolumn{4}{c}{ Subconjunto 1 } & \multicolumn{3}{c}{ Subconjunto 2 } \\
\cline { 2 - 7 } Variáveis & 1 & 2 & 3 & 1 & 2 & 3 \\
\hline Déficit_Inst_Saladeaula & 0,030 & 0,030 & 0,938 & 0,041 & $-0,001$ & 0,926 \\
Déficit_Inst_Sanitáriodosestudantes & 0,018 & 0,692 & $-0,106$ & 0,013 & 0,701 & $-0,120$ \\
Déficit_Inst_Saladeprofessores & 0,517 & 0,451 & $-0,146$ & 0,493 & 0,483 & $-0,105$ \\
Déficit_Inst_BibliotecaouSaladeleitura & 0,512 & 0,423 & $-0,060$ & 0,525 & 0,415 & $-0,072$ \\
Déficit_Inst_Refeitório & 0,644 & 0,131 & 0,103 & 0,630 & 0,141 & 0,049 \\
Déficit_Inst_Cozinha & $-0,026$ & 0,683 & 0,271 & $-0,024$ & 0,657 & 0,351 \\
Déficit_Inst_Quadradeesportescoberta & 0,629 & 0,109 & $-0,150$ & 0,631 & 0,129 & $-0,149$ \\
Déficit_Inst_SaladeTVevídeo & 0,620 & $-0,021$ & 0,143 & 0,615 & $-0,013$ & 0,099 \\
Déficit_Inst_Laboratóriodeciências & 0,605 & $-0,129$ & $-0,023$ & 0,611 & $-0,132$ & 0,060 \\
\hline
\end{tabular}




\section{ANEXO IV}

Resultados da Análise Fatorial para Déficits de Mobiliários - Modelo Final

Tabela 1 - Matriz de Correlações, Medida de Adequação da Amostra (MSA) e Teste Bartlett para as variáveis indicativas dos déficits de Mobiliários das escolas.

\begin{tabular}{|c|c|c|c|c|c|c|c|c|c|c|c|c|c|c|c|}
\hline & \multirow[b]{2}{*}{ Variável } & \multicolumn{14}{|c|}{ Correlação entre variáveis } \\
\hline & & $\mathrm{X} 1$ & $\mathrm{X} 2$ & $\mathrm{X} 3$ & $\mathrm{X} 4$ & $\mathrm{X} 5$ & $\mathrm{X} 6$ & X7 & $\mathrm{X} 8$ & $\mathrm{X9}$ & $\mathrm{X} 10$ & $\mathrm{X} 11$ & $\mathrm{X} 12$ & $\mathrm{X} 13$ & $\mathrm{X} 14$ \\
\hline $\mathrm{X} 1$ & Déficit_Mob_Cadeiras & 1,00 & & & & & & & & & & & & & \\
\hline $\mathrm{X} 2$ & Déficit_Mob_Carteiras & $0,34^{*}$ & 1,00 & & & & & & & & & & & & \\
\hline X3 & Déficit_Mob_SuportesparaTVeDVD & $0,47^{*}$ & $0,25^{\star}$ & 1,00 & & & & & & & & & & & \\
\hline $\mathrm{X} 4$ & Déficit_Mob_Quadrosparasaladeaula & $0,41^{*}$ & $0,40^{*}$ & $0,56^{*}$ & 1,00 & & & & & & & & & & \\
\hline $\mathrm{X} 5$ & Déficit_Mob_Arquivosdeaço & $0,51^{*}$ & $0,33^{*}$ & $0,76^{*}$ & $0,58^{*}$ & 1,00 & & & & & & & & & \\
\hline $\mathrm{X} 6$ & Déficit_Mob_Armários & $0,54^{*}$ & $0,38^{*}$ & $0,60^{*}$ & $0,57^{*}$ & $0,60^{*}$ & 1,00 & & & & & & & & \\
\hline $\mathrm{X} 7$ & Déficit_Mob_Mesastipoescrivaninha & $0,43^{*}$ & $0,23^{*}$ & $0,54^{*}$ & $0,48^{*}$ & $0,54^{*}$ & $0,53^{*}$ & 1,00 & & & & & & & \\
\hline $\mathrm{X} 8$ & Déficit_Mob_Estantesparabiblioteca & $0,51^{*}$ & $0,30^{*}$ & $0,81^{*}$ & $0,48^{*}$ & $0,70^{*}$ & $0,58^{*}$ & $0,52^{*}$ & 1,00 & & & & & & \\
\hline X9 & Déficit_Mob_Mesasparaimpressora & $0,17^{\star}$ & $0,11^{*}$ & $0,08^{*}$ & $0,11^{*}$ & $0,11^{*}$ & $0,19^{*}$ & $0,14^{\star}$ & $0,11^{*}$ & 1,00 & & & & & \\
\hline $\mathrm{X} 10$ & Déficit_Mob_Mesasparacomputador & $0,20^{*}$ & $0,14^{*}$ & $0,02^{*}$ & $0,12^{*}$ & $0,11^{*}$ & $0,22^{*}$ & $0,16^{*}$ & $0,06^{*}$ & $0,44^{*}$ & 1,00 & & & & \\
\hline $\mathrm{X} 11$ & Déficit_Mob_Mesaspararefeitório & $0,22^{*}$ & $0,15^{\star}$ & $-0,03^{*}$ & $0,10^{*}$ & $0,09^{*}$ & $0,21^{*}$ & $0,12^{*}$ & $0,02^{*}$ & $0,38^{*}$ & $0,38^{*}$ & 1,00 & & & \\
\hline $\mathrm{X} 12$ & Déficit_Mob_Mesasdeleitura & $0,06^{*}$ & $0,11^{*}$ & $-0,11^{*}$ & $0,08^{*}$ & $-0,01$ & $0,08^{*}$ & $0,07^{\star}$ & $-0,05^{\star}$ & $0,21^{*}$ & $0,25^{\star}$ & $0,29 *$ & 1,00 & & \\
\hline $\mathrm{X} 13$ & Déficit_Mob_Mesasdereuniãodasaladeprofessores & $0,16^{*}$ & $0,16^{*}$ & $-0,03^{*}$ & $0,13^{*}$ & $0,07^{*}$ & $0,18^{*}$ & $0,12^{*}$ & $0,02^{*}$ & $0,46^{*}$ & $0,39^{*}$ & $0,43^{*}$ & $0,29^{*}$ & 1,00 & \\
\hline $\mathrm{X} 14$ & Déficit Mob_Armáriosparasecretaria & $0,15^{*}$ & $0,20^{*}$ & $0,03^{*}$ & $0,19^{*}$ & $0,09^{*}$ & $0,19^{*}$ & $0,14^{*}$ & $0,07^{*}$ & $0,30^{*}$ & $0,26^{*}$ & $0,23^{*}$ & $0,19^{*}$ & $0,36^{*}$ & 1,00 \\
\hline
\end{tabular}


Tabela 2 - Matriz Anti-Imagem para as Covariâncias e Correlações Parciais entre as variáveis relativas aos déficits de Mobiliários das escolas.

\begin{tabular}{|c|c|c|c|c|c|c|c|c|c|c|c|c|c|c|c|c|}
\hline & & \multirow{2}{*}{ Variável } & \multicolumn{12}{|c|}{ Medidas de adequação da amostra e correlações parciais } & \multirow[b]{2}{*}{$\mathrm{X} 13$} & \multirow[b]{2}{*}{$\mathrm{X} 14$} \\
\hline & & & $\mathrm{X} 1$ & $\mathrm{X} 2$ & $\mathrm{X} 3$ & $\mathrm{X} 4$ & $\mathrm{X} 5$ & $\mathrm{X} 6$ & $\mathrm{X} 7$ & $\mathrm{X} 8$ & $\mathrm{X9}$ & $\mathrm{X} 10$ & $\mathrm{X} 11$ & $\mathrm{X} 12$ & & \\
\hline \multirow{28}{*}{ Covariâncias } & $\mathrm{X} 1$ & Déficit_Mob_Cadeiras & ,598 & & & & & & & & & & & & & \\
\hline & $\mathrm{x} 2$ & Déficit Mob Carteiras &,- 074 & ,759 & & & & & & & & & & & & \\
\hline & X3 & Déficit Mob SuportesparaTVeDVD & ,000 & ,043 & ,239 & & & & & & & & & & & \\
\hline & X4 & Déficit_Mob_Quadrosparasaladeaula &,- 011 &,- 133 &,- 066 &, 521 & & & & & & & & & & \\
\hline & $\mathrm{X} 5$ & Déficit_Mob_Arquivosdeaço &,- 043 &,- 033 &,- 100 &,- 069 & ,353 & & & & & & & & & \\
\hline & $\mathrm{X} 6$ & Déficit_Mob_Armários &,- 094 &,- 069 &,- 049 &,- 091 &,- 031 & ,448 & & & & & & & & \\
\hline & $\mathrm{X} 7$ & Déficit_Mob_Mesastipoescrivaninha &,- 051 &, 043 &,- 031 &,- 073 &,- 049 &,- 075 &, 595 & & & & & & & \\
\hline & $\mathrm{x} 8$ & Déficit_Mob_Estantesparabiblioteca &,- 066 &,- 042 &,- 144 &, 036 &,- 050 &,- 027 &,- 038 & ,303 & & & & & & \\
\hline & X9 & Déficit_Mob_Mesasparaimpressora &, 000 &, 020 &,- 021 & 017 &, 012 & ,002 &, 003 &,- 019 & 670 & & & & & \\
\hline & $\mathrm{X} 10$ & Déficit_Mob_Mesasparacomputador &,- 033 &,- 010 &, 016 &, 014 &,- 014 &,- 044 &,- 033 &, 017 &,- 179 & ,701 & & & & \\
\hline & $\mathrm{X} 11$ & Déficit_Mob_Mesaspararefeitório &,- 079 &,- 015 &, 041 &, 013 &,- 025 &,- 049 &,- 007 &, 013 &,- 100 &,- 102 & ,691 & & & \\
\hline & $\mathrm{X} 12$ & Déficit ${ }^{-}$Mob ${ }^{-}$Mesasdeleitura &, 009 &,- 030 & 057 &,- 052 &, $001^{*}$ &,- 015 &,- 034 &,- 008 &,- 021 &,- 069 &,- 103 & ,838 & & \\
\hline & $\mathrm{X} 13$ & Déficit Mob Mesasdereuniãodasaladeprofessores &,- 011 &,- 018 & ,022 &,- 016 &,- 007 &,- 022 &,- 014 & 011 &,- 169 &,- 081 &,- 139 &,- 078 & ,640 & \\
\hline & $X 14$ & Déficit_Mob_Armáriosparasecretaria &,- 001 &,- 071 &, 028 &,- 060 &, 012 &,- 024 &,- 019 &,- 012 &,- 090 &,- 045 &,- 009 &,- 032 &,- 133 & ,808 \\
\hline & $\mathrm{X} 1$ & Déficit_Mob_Cadeiras &, $942 a$ & & & & & & & & & & & & & \\
\hline & $\mathrm{X} 2$ & Déficit_Mob_Carteiras &,- 110 & ,889a & & & & & & & & & & & & \\
\hline & X3 & Déficit Mob SuportesparaTVeDVD &, 001 &, 102 & ,829a & & & & & & & & & & & \\
\hline & $\mathrm{X} 4$ & Déficit_Mob_Quadrosparasaladeaula &,- 020 &,- 212 &,- 188 &, $910 a$ & & & & & & & & & & \\
\hline & X5 & Déficit_Mob_Arquivosdeaço &,- 093 &,- 065 &,- 345 &,- 162 & ,923a & & & & & & & & & \\
\hline & $\mathrm{X} 6$ & Déficit_Mob_Armários &,- 182 &,- 118 &,- 148 &,- 187 &,- 078 &, $937 a$ & & & & & & & & \\
\hline & $\mathrm{X} 7$ & Déficit Mob Mesastipoescrivaninha &,- 085 & ,064 &,- 083 &,- 130 &,- 107 &,- 145 &, $954 a$ & & & & & & & \\
\hline & $\mathrm{X} 8$ & Déficit_Mob_Estantesparabiblioteca &,- 156 &,- 088 &,- 535 & ,090 &,- 152 &,- 074 &,- 089 &, $865 a$ & & & & & & \\
\hline & X9 & Déficit_Mob_Mesasparaimpressora &, 000 & ,028 &,- 054 & ,030 & ,025 & ,004 &, 004 &,- 042 & ,822a & & & & & \\
\hline & $\mathrm{X} 10$ & Déficit_Mob_Mesasparacomputador &,- 051 &,- 013 &, 040 & ,023 &,- 027 &,- 079 &,- 052 &, 037 &,- 261 & ,857a & & & & \\
\hline & $\mathrm{X} 11$ & Déficit_Mob_Mesaspararefeitório &,- 123 &,- 021 &, 101 &, 022 &,- 052 &,- 088 &,- 011 & ,029 &,- 146 &,- 147 & ,843a & & & \\
\hline & $\mathrm{X} 12$ & Déficit_Mob_Mesasdeleitura &, 013 &,- 037 & ,128 &,- 079 & ,002 &,- 024 &,- 048 &,- 016 &,- 028 &,- 090 &,- 135 & ,844a & & \\
\hline & $\mathrm{X} 13$ & Déficit_Mob_Mesasdereuniãodasaladeprofessores &,- 018 &,- 026 & ,057 &,- 027 &,- 014 &,- 040 &,- 022 & ,026 &,- 259 &,- 121 &,- 209 &,- 107 &, $833 \mathbf{a}$ & \\
\hline & $\mathrm{X} 14$ & Déficit_Mob_Armáriosparasecretaria &,- 002 &,- 091 &, 064 &,- 092 &, 022 &,- 039 &,- 027 &,- 024 &,- 123 &,- 059 &,- 012 &,- 039 &,- 185 & ,872a \\
\hline
\end{tabular}


Tabela 3 - Autovalores e variância explicada pelos fatores componentes identificados referentes aos Déficits de Mobiliários das escolas.

\begin{tabular}{cccc}
\hline Componente & Autovalores & $\begin{array}{c}\text { \% de variância } \\
\text { explicada }\end{array}$ & $\begin{array}{c}\text { \% cumulativo de } \\
\text { variância explicada }\end{array}$ \\
\hline $\mathbf{1}$ & $\mathbf{4 , 8 1 6}$ & $\mathbf{3 4 , 4 0}$ & $\mathbf{3 4 , 4 0}$ \\
$\mathbf{2}$ & $\mathbf{2 , 5 5 0}$ & $\mathbf{1 8 , 2 2}$ & $\mathbf{5 2 , 6 1}$ \\
3 & 0,935 & 6,68 & 59,29 \\
4 & 0,843 & 6,02 & 65,31 \\
5 & 0,751 & 5,36 & 70,68 \\
6 & 0,639 & 4,57 & 75,24 \\
7 & 0,599 & 4,28 & 79,52 \\
8 & 0,567 & 4,05 & 83,57 \\
9 & 0,515 & 3,68 & 87,25 \\
10 & 0,488 & 3,49 & 90,73 \\
11 & 0,461 & 3,29 & 94,03 \\
12 & 0,386 & 2,76 & 96,79 \\
13 & 0,285 & 2,03 & 98,82 \\
14 & 0,165 & 1,18 & 100,00 \\
\hline
\end{tabular}

Gráfico 1 - Teste scree para análise das componentes referentes aos Déficits de Mobiliários das escolas.

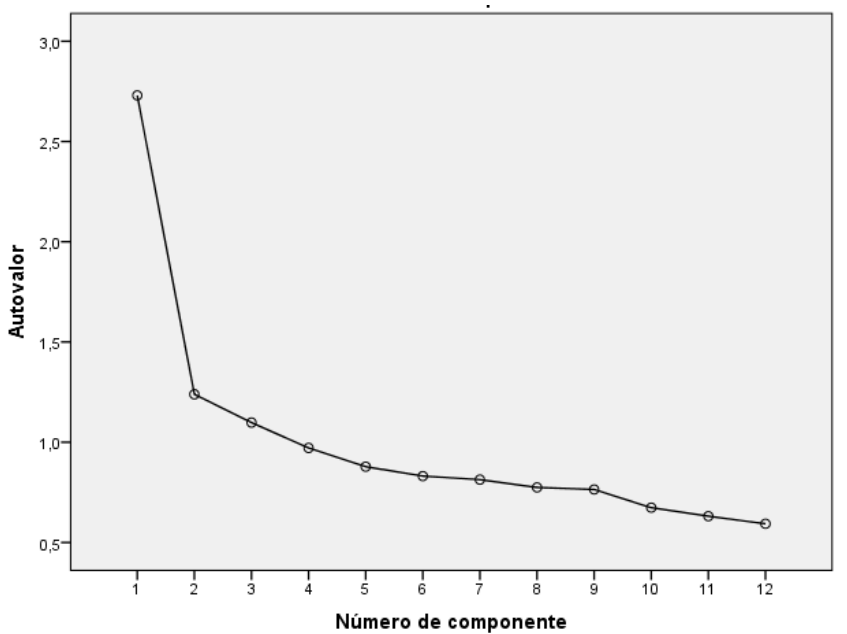

Tabela 4 - Matriz fatorial rotacionada das componentes extraídas referentes aos Déficits de Mobiliários das escolas. 


\begin{tabular}{lrrcc}
\hline \multicolumn{1}{c}{ Variáveis } & \multicolumn{2}{c}{ Componentes } & \multirow{2}{*}{ Comunalidade } \\
\cline { 5 - 5 } Déficit_Mob_Cadeiras & 0,672 & 0,208 & 0,495 \\
Déficit_Mob_Carteiras & 0,459 & 0,238 & 0,267 \\
Déficit_Mob_SuportesparaTVeDVD & 0,879 & $-0,146$ & 0,793 \\
Déficit_Mob_Quadrosparasaladeaula & 0,732 & 0,120 & 0,551 \\
Déficit_Mob_Arquivosdeaço & 0,855 & 0,001 & 0,732 \\
Déficit_Mob_Armários & 0,783 & 0,210 & 0,657 \\
Déficit_Mob_Mesastipoescrivaninha & 0,702 & 0,118 & 0,507 \\
Déficit_Mob_Estantesparabiblioteca & 0,851 & $-0,073$ & 0,730 \\
Déficit_Mob_Mesasparaimpressora & 0,117 & 0,687 & 0,485 \\
Déficit_Mob_Mesasparacomputador & 0,108 & 0,683 & 0,479 \\
Déficit_Mob_Mesaspararefeitório & 0,072 & 0,696 & 0,490 \\
Déficit_Mob_Mesasdeleitura & $-0,041$ & 0,542 & 0,296 \\
Déficit_Mob_Mesasdereuniãodasaladeprofessores & 0,056 & 0,753 & 0,571 \\
Déficit_Mob_Armáriosparasecretaria & 0,126 & 0,547 & 0,315 \\
\hline
\end{tabular}

Tabela 5 - Matriz fatorial rotacionada dos dois subconjuntos utilizados para validação do modelo fatorial referente aos Déficits de Mobiliários das escolas.

\begin{tabular}{lcccc}
\hline \multirow{2}{*}{ Variáveis } & \multicolumn{2}{c}{ Subconjunto 1 } & \multicolumn{2}{c}{ Subconjunto 2 } \\
\cline { 2 - 5 } & 1 & 2 & 1 & 2 \\
\hline Déficit_Mob_Cadeiras & 0,666 & 0,210 & 0,678 & 0,207 \\
Déficit_Mob_Carteiras & 0,454 & 0,242 & 0,463 & 0,234 \\
Déficit_Mob_SuportesparaTVeDVD & 0,877 & $-0,148$ & 0,880 & $-0,145$ \\
Déficit_Mob_Quadrosparasaladeaula & 0,728 & 0,115 & 0,736 & 0,126 \\
Déficit_Mob_Arquivosdeaço & 0,853 & 0,003 & 0,858 & $-0,001$ \\
Déficit_Mob_Armários & 0,778 & 0,218 & 0,788 & 0,203 \\
Déficit_Mob_Mesastipoescrivaninha & 0,707 & 0,115 & 0,697 & 0,121 \\
Déficit_Mob_Estantesparabiblioteca & 0,852 & $-0,077$ & 0,850 & $-0,068$ \\
Déficit_Mob_Mesasparaimpressora & 0,120 & 0,680 & 0,114 & 0,693 \\
Déficit_Mob_Mesasparacomputador & 0,109 & 0,679 & 0,106 & 0,688 \\
Déficit_Mob_Mesaspararefeitório & 0,072 & 0,698 & 0,071 & 0,694 \\
Déficit_Mob_Mesasdeleitura & $-0,050$ & 0,550 & $-0,033$ & 0,534 \\
Déficit_Mob_Mesasdereuniãodasaladeprofessores & 0,060 & 0,755 & 0,052 & 0,751 \\
Déficit_Mob_Armáriosparasecretaria & 0,121 & 0,548 & 0,130 & 0,546 \\
\hline
\end{tabular}


ANEXO V

Resultados da Análise Fatorial para Déficits de Equipamentos - 1ำ Modelo

Tabela 1 - Matriz de Correlações, Medida de Adequação da Amostra (MSA) e Teste Bartlett para as variáveis indicativas dos déficits de Equipamentos das escolas.

\begin{tabular}{|c|c|c|c|c|c|c|c|c|c|c|c|c|c|c|c|c|c|c|c|c|c|c|}
\hline \multirow{2}{*}{\multicolumn{2}{|c|}{ Variável }} & \multicolumn{21}{|c|}{ Correlação entre variáveis } \\
\hline & & $\mathrm{X} 1$ & $\mathrm{X} 2$ & $\mathrm{X} 3$ & $\mathrm{X} 4$ & $\mathrm{X} 5$ & $\mathrm{X} 6$ & $\mathrm{X7}$ & $\mathrm{X} 8$ & $\mathrm{X9}$ & $\mathrm{X} 10$ & $\mathrm{X} 11$ & $\mathrm{X} 12$ & $\mathrm{X} 13$ & $\mathrm{X} 14$ & $\mathrm{X} 15$ & $\mathrm{X} 16$ & $\mathrm{X} 17$ & $\mathrm{X} 18$ & $\mathrm{X} 19$ & $\mathrm{X} 20$ & $\mathrm{X} 21$ \\
\hline $\mathrm{X} 1$ & Déficit_Equip_Televisores & 1,00 & & & & & & & & & & & & & & & & & & & & \\
\hline $\mathrm{x} 2$ & Déficit_Equip_AparelhosdeDVD & $0,96^{*}$ & 1,00 & & & & & & & & & & & & & & & & & & & \\
\hline $\mathrm{X} 3$ & Déficit_Equip_AparelhosdeCDerádio & $0,88^{*}$ & $0,90^{*}$ & 1,00 & & & & & & & & & & & & & & & & & & \\
\hline $\mathrm{X} 4$ & Déficit_Equip_Circuladoresdear & $0,64^{*}$ & $0,64^{*}$ & $0,63^{*}$ & 1,00 & & & & & & & & & & & & & & & & & \\
\hline$x 5$ & $\begin{array}{l}\text { Déficit_Equip_Computadoresparaadminist } \\
\text { raçãodocentes }\end{array}$ & $-0,03^{*}$ & $-0,05^{\star}$ & $0,03^{*}$ & $-0,01$ & 1,00 & & & & & & & & & & & & & & & & \\
\hline $\mathrm{X} 6$ & $\begin{array}{l}\text { Déficit_Equip_Computadoresparasaladeinf } \\
\text { ormática }\end{array}$ & $-0,06^{\star}$ & $-0,07^{*}$ & $-0,01$ & $-0,03^{*}$ & $0,36^{*}$ & 1,00 & & & & & & & & & & & & & & & \\
\hline $\mathrm{X} 7$ & Déficit_Equip_Retroprojetores & $-0,02$ & $-0,04^{*}$ & 0,01 & $-0,02^{*}$ & $0,16^{*}$ & $0,16^{*}$ & 1,00 & & & & & & & & & & & & & & \\
\hline $\mathrm{x} 8$ & Déficit_Equip_Telasparaprojeção & $-0,07^{*}$ & $-0,10^{*}$ & $-0,03^{\star}$ & $-0,06^{\star}$ & $0,26^{*}$ & $0,20^{*}$ & $0,29 *$ & 1,00 & & & & & & & & & & & & & \\
\hline X9 & Déficit_Equip_Bebedouroselétricos & $0,04^{*}$ & $0,03^{*}$ & $0,08^{*}$ & $0,06^{*}$ & $0,36^{*}$ & $0,25^{*}$ & $0,04^{*}$ & $0,07^{*}$ & 1,00 & & & & & & & & & & & & \\
\hline $\mathrm{X} 10$ & Déficit_Equip_Freezers & $-0,02^{*}$ & $-0,02^{*}$ & $0,02^{*}$ & $-0,01$ & $0,30^{*}$ & $0,24^{*}$ & $0,06^{*}$ & $0,11^{*}$ & $0,38^{*}$ & 1,00 & & & & & & & & & & & \\
\hline $\mathrm{X} 11$ & Déficit_Equip_Geladeiras & $0,12^{*}$ & $0,11^{*}$ & $0,16^{*}$ & $0,10^{*}$ & $0,37^{*}$ & $0,26^{*}$ & $0,09^{*}$ & $0,13^{*}$ & $0,42^{*}$ & $0,43^{*}$ & 1,00 & & & & & & & & & & \\
\hline $\mathrm{X} 12$ & Déficit_Equip_Fogãoõesindustrialais & $0,09^{*}$ & $0,10^{*}$ & $0,13^{*}$ & $0,07^{\star}$ & $0,30^{*}$ & $0,22^{*}$ & 0,00 & $0,02^{*}$ & $0,46^{*}$ & $0,48^{*}$ & $0,47^{*}$ & 1,00 & & & & & & & & & \\
\hline $\mathrm{X} 13$ & Déficit_Equip_Liquidificadoresindustrialais & $0,05^{\star}$ & $0,06^{*}$ & $0,10^{*}$ & $0,04^{*}$ & $0,31^{*}$ & $0,22^{*}$ & $0,03^{*}$ & $0,07^{*}$ & $0,45^{*}$ & $0,48^{*}$ & $0,45^{*}$ & $0,55^{*}$ & 1,00 & & & & & & & & \\
\hline $\mathrm{X} 14$ & Déficit_Equip_Botijãoõesdegás & $-0,04^{*}$ & $-0,05^{*}$ & $-0,01$ & $-0,01$ & $0,19^{*}$ & $0,20^{*}$ & $0,16^{*}$ & $0,22^{*}$ & $0,14^{*}$ & $0,33^{*}$ & $0,25^{*}$ & $0,25^{*}$ & $0,24^{*}$ & $1,00^{*}$ & & & & & & & \\
\hline $\mathrm{X} 15$ & Déficit_Equip_Máquinasfotográficas & 0,01 & 0,00 & $0,06^{*}$ & 0,00 & $0,23^{*}$ & $0,22^{*}$ & $0,20^{*}$ & $0,29^{*}$ & $0,13^{*}$ & $0,15^{\star}$ & $0,18^{*}$ & $0,09^{*}$ & $0,12^{*}$ & $0,22^{*}$ & $1,00^{*}$ & & & & & & \\
\hline $\mathrm{X} 16$ & Déficit_Equip_Impressoraslaser & $0,09^{*}$ & $0,08^{*}$ & $0,12^{*}$ & $0,06^{*}$ & $0,35^{*}$ & $0,24^{*}$ & $0,08^{*}$ & $0,11^{*}$ & $0,34^{*}$ & $0,27^{*}$ & $0,33^{*}$ & $0,35^{*}$ & $0,33^{*}$ & $0,13^{*}$ & $0,17^{*}$ & $1,00^{*}$ & & & & & \\
\hline $\mathrm{X} 17$ & Déficit_Equip_Impressorasjatodetinta & $0,08^{*}$ & $0,07^{*}$ & $0,12^{*}$ & $0,06^{\star}$ & $0,33^{*}$ & $0,25^{*}$ & $0,09^{*}$ & $0,11^{*}$ & $0,35^{*}$ & $0,28^{*}$ & $0,33^{*}$ & $0,34^{*}$ & $0,33^{*}$ & $0,15^{*}$ & $0,18^{*}$ & $0,18^{*}$ & 1,00 & & & & \\
\hline $\mathrm{X} 18$ & Déficit_Equip_Fotocopiadoras & $-0,07^{*}$ & $-0,09^{*}$ & $-0,04^{*}$ & $-0,02^{*}$ & $0,19^{*}$ & $0,16^{*}$ & $0,17^{*}$ & $0,22^{*}$ & $0,08^{*}$ & $0,10^{*}$ & $0,12^{*}$ & $0,02^{*}$ & $0,05^{\star}$ & $0,16^{*}$ & $0,17^{\star}$ & $0,04^{*}$ & $0,09^{*}$ & 1,00 & & & \\
\hline $\mathrm{X} 19$ & Déficit_Equip_Guilhotinasdepapel & $-0,10^{*}$ & $-0,12^{*}$ & $-0,04^{*}$ & $-0,06^{*}$ & $0,35^{*}$ & $0,23^{*}$ & $0,23^{*}$ & $0,32^{*}$ & $0,11^{*}$ & $0,14^{*}$ & $0,18^{*}$ & $0,06^{*}$ & $0,11^{*}$ & $0,19^{*}$ & $0,22^{*}$ & $0,15^{\star}$ & $0,14^{*}$ & $0,23^{*}$ & 1,00 & & \\
\hline X20 & Déficit_Equip_Máquinasdelavarroupa & $0,03^{*}$ & $0,02^{*}$ & $0,08^{*}$ & $0,04^{*}$ & $0,24^{*}$ & $0,18^{*}$ & $0,14^{*}$ & $0,15^{\star}$ & $0,11^{*}$ & $0,10^{*}$ & $0,14^{*}$ & $0,06^{*}$ & $0,06^{\star}$ & $0,10^{*}$ & $0,13^{*}$ & $0,11^{*}$ & $0,09^{*}$ & $0,13^{*}$ & $0,22^{*}$ & 1,00 & \\
\hline $\mathrm{X} 21$ & Déficit_Equip_Aparelhosdetelefone & $0,10^{*}$ & $0,08^{*}$ & $0,17^{\star}$ & $0,10^{*}$ & $0,53^{*}$ & $0,31^{*}$ & $0,14^{*}$ & $0,22^{*}$ & $0,39^{*}$ & $0,33^{*}$ & $0,47^{*}$ & $0,33^{*}$ & $0,36^{*}$ & $0,18^{*}$ & $0,20^{*}$ & $0,32^{*}$ & $0,32^{*}$ & $0,19^{*}$ & $0,36^{*}$ & $0,27^{\star}$ & 1,00 \\
\hline
\end{tabular}

Teste Bartlett de Esfericidade: 171.350 Significância: 0,0000

*Indica as correlações significantes ao nível de 0,01. 
Tabela 2 - Matriz Anti-Imagem para as Covariâncias e Correlações Parciais entre as variáveis relativas aos déficits de Equipamentos das escolas.

\begin{tabular}{|c|c|c|c|c|c|c|c|c|c|c|c|c|c|c|c|c|c|c|c|c|c|c|c|}
\hline & \multirow{2}{*}{\multicolumn{2}{|c|}{ Variáveis }} & \multicolumn{21}{|c|}{ Medidas de adequação da amostra e correlações parciais } \\
\hline \multirow{22}{*}{$\begin{array}{c}\text { Cova- } \\
\text { riâncias }\end{array}$} & & & $\mathrm{X} 1$ & $\mathrm{X} 2$ & $\mathrm{X} 3$ & $\mathrm{X} 4$ & $\mathrm{X} 5$ & $\mathrm{X} 6$ & $\mathrm{X} 7$ & $\mathrm{X} 8$ & $\mathrm{X9}$ & $\mathrm{X} 10$ & $\mathrm{X} 11$ & $\mathrm{X} 12$ & $\mathrm{X} 13$ & $\mathrm{X} 14$ & $\mathrm{X} 15$ & $\mathrm{X} 16$ & $\mathrm{X} 17$ & $\mathrm{X} 18$ & $\mathrm{X} 19$ & $\mathrm{X} 20$ & $\mathrm{X} 21$ \\
\hline & $\mathrm{X} 1$ & Déficit_Equip_Televisores & 081 & & & & & & & & & & & & & & & & & & & & \\
\hline & $\mathrm{X} 2$ & Déficit_Equip_AparelhosdeDVD &,- 056 &, 064 & & & & & & & & & & & & & & & & & & & \\
\hline & X3 & Déficit_Equip_AparelhosdeCDerádio &,- 013 &,- 045 & ,162 & & & & & & & & & & & & & & & & & & \\
\hline & $\mathrm{X} 4$ & Déficit_Equip_Circuladoresdear &,- 014 &,- 016 &,- 041 &, 566 & & & & & & & & & & & & & & & & & \\
\hline & X5 & $\begin{array}{l}\text { Déficit_Equip_Computadoresparaad } \\
\text { ministraçãodocentes }\end{array}$ &,- 009 &, 014 &,- 010 & ,010 &, 587 & & & & & & & & & & & & & & & & \\
\hline & $\mathrm{X} 6$ & $\begin{array}{l}\text { Déficit_Equip_Computadoresparasal } \\
\text { adeinformática }\end{array}$ &,- 001 &, 008 &,- 007 & ,003 &,- 081 & ,784 & & & & & & & & & & & & & & & \\
\hline & $\mathrm{X} 7$ & Déficit_Equip_Retroprojetores &,- 008 &, 007 &,- 004 & 008 &,- 011 &,- 042 & 865 & & & & & & & & & & & & & & \\
\hline & $\mathrm{X9}$ & Déficit_Equip_Bebedouroselétricos & ,003 &,- 001 & ,006 &,- 021 &,- 049 &,- 033 & 013 &, 015 & ,638 & & & & & & & & & & & & \\
\hline & $\mathrm{X} 10$ & Déficit_Equip_Freezers &,- 001 & 003 &, 005 & 008 &,- 008 &,- 024 & 011 &,- 004 &,- 047 & 627 & & & & & & & & & & & \\
\hline & $\mathrm{X} 11$ & Déficit_Equip_Geladeiras &,- 004 &, 002 &,- 009 &,- 008 &,- 020 &,- 013 &,- 007 &,- 004 &,- 060 &,- 081 &, 597 & & & & & & & & & & \\
\hline & $\mathrm{X} 12$ & Déficit_Equip_Fogãoõesindustrialais & 006 &,- 007 &,- 002 & 005 &,- 018 &,- 019 & 023 &, 039 &,- 090 &,- 114 &,- 090 &, 546 & & & & & & & & & \\
\hline & $\mathrm{X} 13$ & $\begin{array}{l}\text { Déficit_Equip_Liquidificadoresindustri } \\
\text { alais }\end{array}$ & 007 &,- 003 &,- 009 & 011 &,- 011 &, 001 &, 015 &, 006 &,- 092 &,- 112 &,- 062 &,- 140 &, 577 & & & & & & & & \\
\hline & $\mathrm{X} 14$ & Déficit_Equip_Botijãoõesdegás &, 003 &,- 001 &, 005 &,- 013 & 009 &,- 038 &,- 054 &,- 081 &, 047 &,- 125 &,- 044 &,- 065 &,- 043 & ,802 & & & & & & & \\
\hline & $\mathrm{X} 15$ & Déficit_Equip_Máquinasfotográficas &, 003 &, 002 &,- 020 &, 013 &,- 028 &,- 056 &,- 068 &,- 128 &,- 007 &,- 009 &,- 021 &, 026 &, 003 &,- 087 & ,829 & & & & & & \\
\hline & $\mathrm{X} 16$ & Déficit_Equip_Impressoraslaser & 001 &,- 004 &,- 004 & ,004 &,- 096 &,- 059 &,- 012 &,- 006 &,- 073 &,- 009 &,- 039 &,- 078 &,- 054 & 018 &,- 051 & ,757 & & & & & \\
\hline & $\mathrm{X} 17$ & Déficit_Equip_Impressorasjatodetinta &, 001 &, 000 &,- 013 &, 003 &,- 076 &,- 062 &,- 023 &,- 002 &,- 083 &,- 021 &,- 047 &,- 061 &,- 054 &, 009 &,- 056 & 055 & ,763 & & & & \\
\hline & $\mathrm{X} 18$ & Déficit_Equip_Fotocopiadoras &,- 002 & 007 &,- 001 &,- 022 &,- 030 &,- 035 &,- 055 &,- 071 &,- 015 &,- 006 &,- 013 & 027 & ,020 &,- 061 &,- 051 & ,035 &,- 002 & 881 & & & \\
\hline & $\mathrm{X} 21$ & Déficit_Equip_Aparelhosdetelefone &,- 009 &, 009 &,- 020 &,- 013 &,- 148 &,- 036 &, 001 &,- 029 &,- 065 &,- 027 &,- 108 &,- 004 &,- 035 & 022 &, 010 &,- 032 &,- 029 &,- 043 &,- 110 &,- 084 &, 553 \\
\hline & $\mathrm{X} 1$ & Déficit_Equip_Televisores & ,777a & & & & & & & & & & & & & & & & & & & & \\
\hline & X2 & Déficit_Equip_AparelhosdeDVD &,- 776 &, $731 a$ & & & & & & & & & & & & & & & & & & & \\
\hline & X3 & Déficit_Equip_AparelhosdeCDerádio &,- 111 &,- 443 & ,896a & & & & & & & & & & & & & & & & & & \\
\hline \multirow{6}{*}{$\begin{array}{l}\text { Corre- } \\
\text { lações } \\
\text { Parciais }\end{array}$} & $\mathrm{X} 4$ & Déficit_Equip_Circuladoresdear &,- 065 &,- 085 &,- 134 & ,973a & & & & & & & & & & & & & & & & & \\
\hline & $\mathrm{X} 5$ & $\begin{array}{l}\text { Déficit_Equip_Computadoresparaad } \\
\text { ministraçãodocentes }\end{array}$ &,- 039 & 073 &,- 033 & 018 & ,906a & & & & & & & & & & & & & & & & \\
\hline & $\mathrm{X} 6$ & $\begin{array}{l}\text { Déficit_Equip_Computadoresparasal } \\
\text { adeinformática }\end{array}$ &,- 004 &, 035 &,- 021 &, 004 &,- 119 & ,944a & & & & & & & & & & & & & & & \\
\hline & $\mathrm{X} 7$ & Déficit_Equip_Retroprojetores &,- 031 &, 028 &,- 011 &, 011 &,- 015 &,- 051 & ,849a & & & & & & & & & & & & & & \\
\hline & $\mathrm{X} 8$ & Déficit_Equip_Telasparaprojeção &,- 023 &, 046 &,- 027 & ,016 &,- 075 &,- 037 &,- 173 &, $852 a$ & & & & & & & & & & & & & \\
\hline & $\mathrm{X9}$ & Déficit_Equip_Bebedouroselétricos &, 013 &,- 006 &, 018 &,- 035 &,- 080 &,- 046 &, 017 &, 022 & ,924a & & & & & & & & & & & & \\
\hline
\end{tabular}

Variáveis

$\begin{array}{llllll} & & & \text { Medidas de adequação da amostra e correlações parciais }\end{array}$

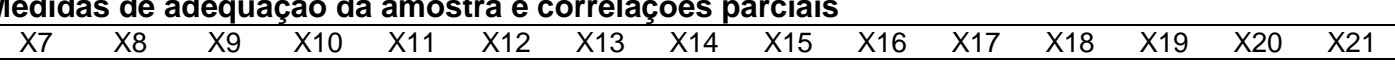




\begin{tabular}{|c|c|c|c|c|c|c|c|c|c|c|c|c|c|c|c|c|c|c|c|c|c|c|c|}
\hline & $\begin{array}{l}\mathrm{X} 10 \\
\mathrm{X} 11 \\
\mathrm{X} 12 \\
\mathrm{X} 13\end{array}$ & $\begin{array}{l}\text { Déficit_Equip_Freezers } \\
\text { Déficit_Equip_Geladeiras } \\
\text { Déficit_Equip_Fogãoõesindustrialais } \\
\text { Déficit_Equip_Liquidificadoresindustri } \\
\text { alais }\end{array}$ & $\begin{array}{l}-, 005 \\
-, 017 \\
, 028 \\
, 031\end{array}$ & $\begin{array}{l}, 015 \\
, 012 \\
-, 040 \\
-, 014\end{array}$ & $\begin{array}{l}, 014 \\
-, 029 \\
-, 006 \\
-, 030\end{array}$ & $\begin{array}{l}, 013 \\
-, 014 \\
009 \\
, 019\end{array}$ & $\begin{array}{l}-, 013 \\
-, 034 \\
-, 031 \\
-, 020\end{array}$ & $\begin{array}{l}-, 035 \\
-, 019 \\
-, 029 \\
, 001\end{array}$ & $\begin{array}{r}, 014 \\
-, 010 \\
, 034 \\
, 022\end{array}$ & $\begin{array}{l}-, 005 \\
-, 005 \\
, 060 \\
, 010\end{array}$ & $\begin{array}{l}-, 074 \\
-, 098 \\
-, 152 \\
-, 151\end{array}$ & $\begin{array}{l}, 913 a \\
-, 132 \\
-, 194 \\
-, 186\end{array}$ & $\begin{array}{l}, 936 \mathbf{a} \\
-, 157 \\
-, 106\end{array}$ & $\begin{array}{c}, 888 \mathbf{a} \\
-, 250\end{array}$ &, $906 a$ & & & & & & & & \\
\hline $\begin{array}{l}\text { Corre- } \\
\text { lações } \\
\text { Parciais }\end{array}$ & $\begin{array}{l}\text { X14 } \\
\text { X15 } \\
\text { X16 } \\
\text { X17 } \\
\text { X18 } \\
\text { X19 } \\
\text { X20 } \\
\text { X21 }\end{array}$ & $\begin{array}{l}\text { Déficit_Equip_Botijãoõesdegás } \\
\text { Déficit_Equip_Máquinasfotográficas } \\
\text { Déficit_Equip_Impressoraslaser } \\
\text { Déficit_Equip_Impressorasjatodetinta } \\
\text { Déficit_Equip_Fotocopiadoras } \\
\text { Déficit_Equip_Guilhotinasdepapel } \\
\text { Déficit_Equip_Máquinasdelavarroupa } \\
\text { Déficit_Equip_Aparelhosdetelefone }\end{array}$ & $\begin{array}{l}, 013 \\
, 010 \\
, 003 \\
, 003 \\
-, 007 \\
, 008 \\
, 003 \\
-, 041\end{array}$ & $\begin{array}{r}-, 006 \\
, 009 \\
-, 018 \\
, 000 \\
, 028 \\
, 050 \\
, 025 \\
, 047\end{array}$ & $\begin{array}{l}, 015 \\
-, 054 \\
-, 011 \\
-, 037 \\
-, 002 \\
-, 052 \\
-, 065 \\
-, 066\end{array}$ & $\begin{array}{r}-, 020 \\
, 019 \\
, 006 \\
, 005 \\
-, 031 \\
, 007 \\
-, 009 \\
-, 024\end{array}$ & $\begin{array}{l}, 014 \\
-, 041 \\
-, 144 \\
-, 114 \\
-, 041 \\
-, 130 \\
-, 075 \\
-, 259\end{array}$ & $\begin{array}{l}-, 047 \\
-, 069 \\
-, 077 \\
-, 080 \\
-, 042 \\
-, 037 \\
-, 060 \\
-, 055\end{array}$ & $\begin{array}{l}-, 065 \\
-, 080 \\
-, 015 \\
-, 029 \\
-, 063 \\
-, 085 \\
-, 054 \\
, 002\end{array}$ & $\begin{array}{l}-, 103 \\
-, 160 \\
-, 008 \\
-, 003 \\
-, 086 \\
-, 139 \\
-, 011 \\
-, 045\end{array}$ & $\begin{array}{l}, 066 \\
-, 010 \\
-, 105 \\
-, 119 \\
-, 020 \\
, 044 \\
-, 010 \\
-, 109\end{array}$ & $\begin{array}{l}-, 176 \\
-, 012 \\
-, 013 \\
-, 030 \\
-, 008 \\
, 000 \\
-, 015 \\
-, 046\end{array}$ & $\begin{array}{l}-, 063 \\
-, 029 \\
-, 057 \\
-, 070 \\
-, 018 \\
-, 011 \\
-, 012 \\
-, 188\end{array}$ & $\begin{array}{c}-, 098 \\
, 039 \\
-, 121 \\
-, 094 \\
, 039 \\
, 061 \\
, 030 \\
-, 008\end{array}$ & $\begin{array}{c}-, 063 \\
, 005 \\
-, 082 \\
-, 082 \\
, 028 \\
, 004 \\
, 051 \\
-, 062\end{array}$ & $\begin{array}{c}, 876 a \\
-, 106 \\
, 023 \\
, 011 \\
-, 073 \\
-, 058 \\
-, 024 \\
, 032\end{array}$ & $\begin{array}{c}, \mathbf{8 8 8 a} \\
-, 064 \\
-, 070 \\
-, 060 \\
-, 054 \\
-, 017 \\
, 015\end{array}$ & $\begin{array}{c}, 926 a \\
, 072 \\
, 043 \\
-, 015 \\
-, 001 \\
-, 049\end{array}$ & $\begin{array}{l}, 933 a \\
-, 003 \\
-, 006 \\
, 023 \\
-, 045\end{array}$ & $\begin{array}{l}, 894 a \\
-, 087 \\
-, 028 \\
-, 061\end{array}$ & $\begin{array}{c}, 883 a \\
-, 085 \\
-, 172\end{array}$ & $\begin{array}{l}, 893 \mathbf{a} \\
-, 121\end{array}$ & ,902a \\
\hline
\end{tabular}


Tabela 3 - Autovalores e variância explicada pelos fatores componentes identificados referentes aos Déficits de Equipamentos das escolas.

\begin{tabular}{cccc}
\hline Componente & Autovalores & $\begin{array}{c}\text { \% de variância } \\
\text { explicada }\end{array}$ & $\begin{array}{c}\text { \% cumulativo de } \\
\text { variância explicada }\end{array}$ \\
\hline $\mathbf{1}$ & $\mathbf{4 , 8 3 2}$ & $\mathbf{2 3 , 0 1}$ & $\mathbf{2 3 , 0 1}$ \\
$\mathbf{2}$ & $\mathbf{3 , 4 2 7}$ & $\mathbf{1 6 , 3 2}$ & $\mathbf{3 9 , 3 3}$ \\
$\mathbf{3}$ & $\mathbf{1 , 8 7 1}$ & $\mathbf{8 , 9 1}$ & $\mathbf{4 8 , 2 4}$ \\
$\mathbf{4}$ & $\mathbf{1 , 0 8 9}$ & $\mathbf{5 , 1 8}$ & $\mathbf{5 3 , 4 2}$ \\
5 & 0,898 & 4,28 & 57,70 \\
6 & 0,861 & 4,10 & 61,80 \\
7 & 0,810 & 3,86 & 65,66 \\
8 & 0,794 & 3,78 & 69,44 \\
9 & 0,766 & 3,65 & 73,08 \\
10 & 0,731 & 3,48 & 76,56 \\
11 & 0,645 & 3,07 & 79,64 \\
12 & 0,614 & 2,93 & 82,56 \\
13 & 0,577 & 2,75 & 85,31 \\
14 & 0,557 & 2,65 & 87,96 \\
15 & 0,529 & 2,52 & 90,48 \\
16 & 0,502 & 2,39 & 92,87 \\
17 & 0,467 & 2,22 & 95,09 \\
18 & 0,451 & 2,15 & 97,24 \\
19 & 0,420 & 2,00 & 99,23 \\
20 & 0,121 & 0,58 & 99,81 \\
21 & 0,039 & 0,19 & 100,00 \\
\hline
\end{tabular}


Gráfico 1 - Teste scree para análise das componentes referentes aos Déficits de Equipamentos das escolas.

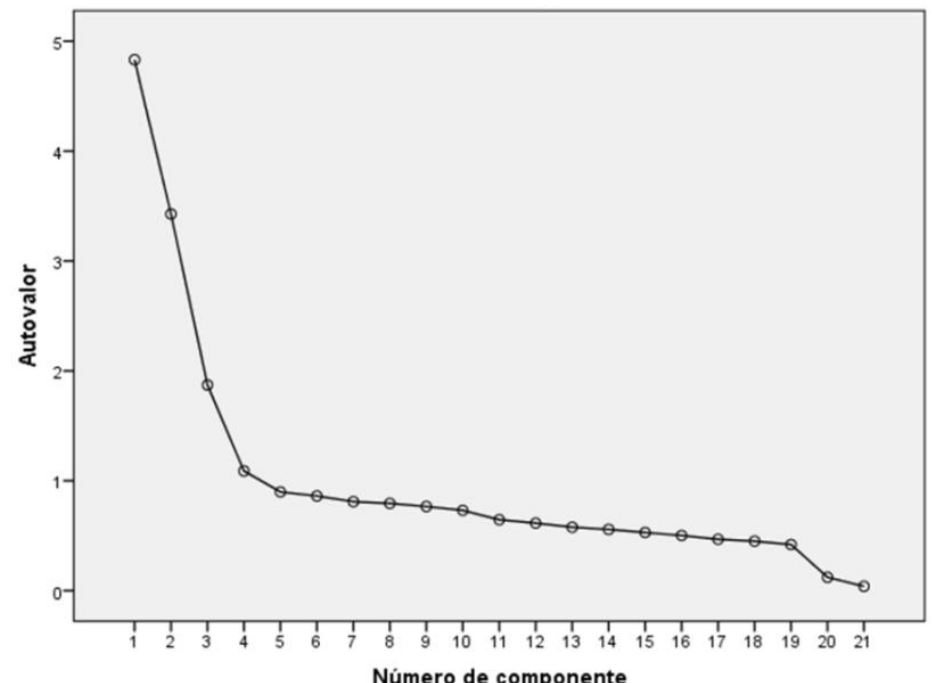


Tabela 4 - Matriz fatorial rotacionada das componentes extraídas referentes aos Déficits de Equipamentos das escolas.

\begin{tabular}{lrrrrc}
\hline & \multicolumn{4}{c}{ Componentes } & \multicolumn{1}{c}{ Comunalidade } \\
\cline { 2 - 5 } Variáveis & \multicolumn{1}{c}{2} & \multicolumn{1}{c}{3} & \multicolumn{1}{c}{4} & Co, \\
Déficit_Equip_Televisores & 0,042 & 0,956 & $-0,039$ & $-0,008$ & 0,918 \\
Déficit_Equip_AparelhosdeDVD & 0,964 & $-0,061$ & $-0,036$ & 0,936 \\
Déficit_Equip_AparelhosdeCDerádio & 0,094 & 0,938 & 0,005 & 0,054 & 0,891 \\
Déficit_Equip_Circuladoresdear & 0,036 & 0,775 & $-0,017$ & 0,012 & 0,602 \\
Déficit_Equip_Computadoresparaadministraçãodocentes & 0,420 & $-0,050$ & 0,197 & 0,609 & 0,589 \\
Déficit_Equip_Computadoresparasaladeinformática & 0,323 & $-0,079$ & 0,250 & 0,387 & $\mathbf{0 , 3 2 3}$ \\
Déficit_Equip_Retroprojetores & $-0,039$ & 0,016 & 0,587 & 0,139 & $\mathbf{0 , 3 6 6}$ \\
Déficit_Equip_Telasparaprojeção & 0,017 & $-0,054$ & 0,659 & 0,208 & $\mathbf{0 , 4 8 1}$ \\
Déficit_Equip_Bebedouroselétricos & 0,669 & 0,008 & $-0,063$ & 0,253 & 0,515 \\
Déficit_Equip_Freezers & 0,716 & $-0,060$ & 0,187 & $-0,055$ & 0,554 \\
Déficit_Equip_Geladeiras & 0,672 & 0,110 & 0,134 & 0,194 & 0,520 \\
Déficit_Equip_Fogãoõesindustrialais & 0,796 & 0,067 & $-0,017$ & $-0,030$ & 0,640 \\
Déficit_Equip_Liquidificadoresindustrialais & 0,771 & 0,021 & 0,034 & 0,005 & 0,596 \\
Déficit_Equip_Botijãoõesdegás & 0,386 & $-0,042$ & 0,595 & $-0,251$ & $\mathbf{0 , 5 6 8}$ \\
Déficit_Equip_Máquinasfotográficas & 0,151 & 0,044 & 0,586 & 0,087 & $\mathbf{0 , 3 7 6}$ \\
Déficit_Equip_Impressoraslaser & 0,486 & 0,077 & 0,005 & 0,308 & $\mathbf{0 , 3 3 7}$ \\
Déficit_Equip_Impressorasjatodetinta & 0,499 & 0,077 & 0,105 & 0,204 & $\mathbf{0 , 3 0 8}$ \\
Déficit_Equip_Fotocopiadoras & 0,013 & $-0,057$ & 0,467 & 0,212 & $\mathbf{0 , 2 6 7}$ \\
Déficit_Equip_Guilhotinasdepapel & 0,061 & $-0,102$ & 0,428 & 0,518 & 0,465 \\
Déficit_Equip_Máquinasdelavarroupa & 0,007 & 0,057 & 0,137 & 0,583 & $\mathbf{0 , 3 6 2}$ \\
Déficit_Equip_Aparelhosdetelefone & 0,467 & 0,106 & 0,160 & 0,593 & 0,606 \\
\hline
\end{tabular}


ANEXO VI

Resultados da Análise Fatorial para Déficits de Equipamentos - Modelo Final

Tabela 1 - Matriz de Correlações, Medida de Adequação da Amostra (MSA) e Teste Bartlett para as variáveis indicativas dos déficits de Equipamentos das escolas (Modelo Final).

\begin{tabular}{|c|c|c|c|c|c|c|c|c|c|c|c|c|c|}
\hline \multirow{2}{*}{\multicolumn{2}{|c|}{ Variável }} & \multicolumn{12}{|c|}{ Correlação entre variáveis } \\
\hline & & $\mathrm{X} 1$ & $\mathrm{X} 2$ & X3 & $\mathrm{X} 4$ & $\times 5$ & X6 & $X 7$ & $\mathrm{X} 8$ & X9 & $\mathrm{X} 10$ & $\mathrm{X} 11$ & $\mathrm{X} 12$ \\
\hline $\mathrm{X} 1$ & Déficit Equip Televisores & 1,00 & & & & & & & & & & & \\
\hline $\mathrm{x} 2$ & Déficit Equip AparelhosdeDVD & 0.96 & 1.00 & & & & & & & & & & \\
\hline $\mathrm{X3}$ & Déficit Equip AparelhosdeCDerádio & 0,88 & 0,90 & 1,00 & & & & & & & & & \\
\hline X4 & Déficit Equip Circuladoresdear & 0,64 & 0,64 & 0,63 & 1,00 & & & & & & & & \\
\hline X5 & Déficit Equip Computadoresparaadministraçãodocentes & $-0,03$ & $-0,05$ & 0,03 & $-0,01^{*}$ & 1,00 & & & & & & & \\
\hline $\mathrm{X} 6$ & Déficit_Equip_Bebedouroselétricos & 0,04 & 0,03 & 0,08 & 0,06 & 0,36 & 1,00 & & & & & & \\
\hline $\mathrm{X} 7$ & Déficit Equip Freezers & $-0,02$ & $-0,02$ & 0,02 & $-0,01^{*}$ & 0,30 & 0,38 & 1,00 & & & & & \\
\hline $\mathrm{x} 8$ & Déficit Equip Geladeiras & 0,12 & 0,11 & 0,16 & 0,10 & 0,37 & 0,42 & 0,43 & 1,00 & & & & \\
\hline X9 & Déficit Equip Fogãoõesindustrialais & 0,09 & 0,10 & 0,13 & 0,07 & 0,30 & 0,46 & 0,48 & 0,47 & 1,00 & & & \\
\hline $\mathrm{X} 10$ & Déficit Equip Liquidificadoresindustrialais & 0,05 & 0,06 & 0,10 & 0,04 & 0,31 & 0,45 & 0,48 & 0,45 & 0,55 & 1,00 & & \\
\hline $\mathrm{X} 11$ & Déficit Equip Guilhotinasdepapel & $-0,10$ & $-0,12$ & $-0,04$ & $-0,06$ & 0,35 & 0,11 & 0,14 & 0,18 & 0,06 & 0,11 & 1,00 & \\
\hline $\mathrm{X} 12$ & Déficit Equip Aparelhosdetelefone & 0,10 & 0,08 & 0,17 & 0,10 & 0,53 & 0,39 & 0,33 & 0,47 & 0,33 & 0,36 & 0,36 & 1,00 \\
\hline
\end{tabular}

Medida Geral da Adequação da Amostra: 0,841

Teste Bartlett de Esfericidade: 139.478 Significância: 0,0000

*Indica as correlações não significantes ao nível de 0,01. 
Tabela 2 - Matriz Anti-Imagem para as Covariâncias e Correlações Parciais entre as variáveis relativas aos déficits de Equipamentos das escolas (Modelo Final).

\begin{tabular}{|c|c|c|c|c|c|c|c|c|c|c|c|c|c|c|}
\hline & & \multirow{2}{*}{ Variável } & \multicolumn{12}{|c|}{ Medidas de adequação da amostra e correlações parciais } \\
\hline \multirow{12}{*}{ Covariâncias } & & & $\mathrm{X} 1$ & $\mathrm{X} 2$ & X3 & $\mathrm{X} 4$ & $x^{5}$ & $\mathrm{X} 6$ & $\mathrm{X} 7$ & $\mathrm{X} 8$ & $\times 9$ & $\dot{x} 10$ & $\mathrm{X} 11$ & $\mathrm{X} 12$ \\
\hline & $\mathrm{X} 1$ & Déficit_Equip_Televisores & 081 & & & & & & & & & & & \\
\hline & $\mathrm{X} 2$ & Déficit_Equip_AparelhosdeDVD &,- 056 & 064 & & & & & & & & & & \\
\hline & X3 & Déficit_Equip_AparelhosdeCDerádio &,- 013 &,- 045 & ,165 & & & & & & & & & \\
\hline & $\mathrm{X} 4$ & Déficit_Equip_Circuladoresdear &,- 014 &,- 016 &,- 041 &, 567 & & & & & & & & \\
\hline & X5 & $\begin{array}{l}\text { Déficit_Equip_Computadoresparaadministraçãodoc } \\
\text { entes }\end{array}$ &,- 010 &, 019 &,- 020 &, 013 &, 638 & & & & & & & \\
\hline & $\mathrm{x} 6$ & Déficit_Equip_Bebedouroselétricos &, 003 &,- 001 &, 003 &,- 021 &,- 080 & ,660 & & & & & & \\
\hline & $\mathrm{X} 7$ & Déficit_Equip_Freezers &,- 001 & ,004 &, 003 &, 006 &,- 022 &,- 047 & ,652 & & & & & \\
\hline & $\mathrm{X} 8$ & Déficit_Equip_Geladeiras &,- 004 & ,003 &,- 012 &,- 008 &,- 041 &,- 071 &,- 098 & 607 & & & & \\
\hline & X9 & Déficit_Equip_Fogãoõesindustrialais & 007 &,- 009 &,- 001 & 005 &,- 032 &,- 109 &,- 135 &,- 105 & ,569 & & & \\
\hline & $\mathrm{X} 10$ & Déficit_Equip_Liquidificadoresindustrialais & 007 &,- 004 &,- 009 & 012 &,- 022 &,- 105 &,- 127 &,- 072 &,- 165 &, 588 & & \\
\hline & $\mathrm{X} 11$ & Déficit_Equip_Guilhotinasdepapel &, 000 & 018 &,- 029 &, 006 &,- 142 & 035 &,- 022 &,- 025 & 053 & ,006 & ,802 & \\
\hline \multirow{13}{*}{$\begin{array}{l}\text { Correlações } \\
\text { Parciais }\end{array}$} & $\mathrm{X} 12$ & Déficit_Equip_Aparelhosdetelefone &,- 009 & 011 &,- 026 &,- 014 &,- 191 &,- 079 &,- 032 &,- 120 &,- 004 &,- 035 &,- 147 & ,571 \\
\hline & $\mathrm{X} 1$ & Déficit_Equip_Televisores & ,774a & & & & & & & & & & & \\
\hline & $\mathrm{X} 2$ & Déficit_Equip_AparelhosdeDVD &,- 777 & ,727a & & & & & & & & & & \\
\hline & X3 & Déficit_Equip_AparelhosdeCDerádio &,- 113 &,- 440 & ,896a & & & & & & & & & \\
\hline & $\mathrm{X} 4$ & Déficit_Equip_Circuladoresdear &,- 064 &,- 086 &,- 133 & ,975a & & & & & & & & \\
\hline & X5 & $\begin{array}{l}\text { Déficit_Equip_Computadoresparaadministraçãodoc } \\
\text { entes }\end{array}$ &,- 045 & ,093 &,- 061 & ,022 & ,840a & & & & & & & \\
\hline & $\mathrm{X} 6$ & Déficit_Equip_Bebedouroselétricos & 014 &,- 006 & ,010 &,- 034 &,- 123 & ,902a & & & & & & \\
\hline & $\mathrm{X} 7$ & Déficit_Equip_Freezers &,- 004 & 021 & ,009 &, 010 &,- 034 &,- 072 & ,890a & & & & & \\
\hline & $\mathrm{X} 8$ & Déficit_Equip_Geladeiras &,- 017 & 016 &,- 039 &,- 014 &,- 066 &,- 112 &,- 156 & ,903a & & & & \\
\hline & X9 & Déficit_Equip_Fogãoõesindustrialais & 033 &,- 049 &,- 004 & 008 &,- 053 &,- 178 &,- 221 &,- 178 & ,854a & & & \\
\hline & $\mathrm{X} 10$ & Déficit_Equip_Liquidificadoresindustrialais & 034 &,- 019 &,- 030 & 021 &,- 036 &,- 169 &,- 204 &,- 120 &,- 285 & ,872a & & \\
\hline & $\mathrm{X} 11$ & Déficit_Equip_Guilhotinasdepapel & 000 & 078 &,- 079 & ,008 &,- 199 & 048 &,- 031 &,- 036 & 079 & 009 & ,770a & \\
\hline & $\mathrm{X} 12$ & Déficit_Equip_Aparelhosdetelefone &,- 044 & ,059 &,- 083 & $\begin{array}{r}-, 025 \\
\end{array}$ &,- 317 &,- 129 &,- 053 & - -203 &,- 008 &,- 061 &,- 217 &, $839 a$ \\
\hline
\end{tabular}


Tabela 3 - Autovalores e variância explicada pelos fatores componentes identificados referentes aos Déficits de Equipamentos das escolas (Modelo Final).

\begin{tabular}{cccc}
\hline Componente & Autovalores & $\begin{array}{c}\text { \% de variância } \\
\text { explicada }\end{array}$ & $\begin{array}{c}\text { \% cumulativo de } \\
\text { variância explicada }\end{array}$ \\
\hline $\mathbf{1}$ & $\mathbf{3 , 7 8 3}$ & $\mathbf{3 1 , 5 2}$ & $\mathbf{3 1 , 5 2}$ \\
$\mathbf{2}$ & $\mathbf{3 , 1 7 9}$ & $\mathbf{2 6 , 4 9}$ & $\mathbf{5 8 , 0 1}$ \\
$\mathbf{3}$ & $\mathbf{1 , 2 2 0}$ & $\mathbf{1 0 , 1 6}$ & $\mathbf{6 8 , 1 7}$ \\
$\mathbf{4}$ & 0,670 & 5,59 & 73,76 \\
5 & 0,573 & 4,77 & 78,53 \\
6 & 0,541 & 4,51 & 83,04 \\
7 & 0,517 & 4,31 & 87,35 \\
8 & 0,470 & 3,92 & 91,27 \\
9 & 0,460 & 3,84 & 95,11 \\
10 & 0,425 & 3,54 & 98,65 \\
11 & 0,123 & 1,02 & 99,67 \\
12 & 0,040 & 0,33 & 100,00 \\
\hline
\end{tabular}

Gráfico 1 - Teste scree para análise das componentes referentes aos Déficits de Equipamentos das escolas (Modelo Final).

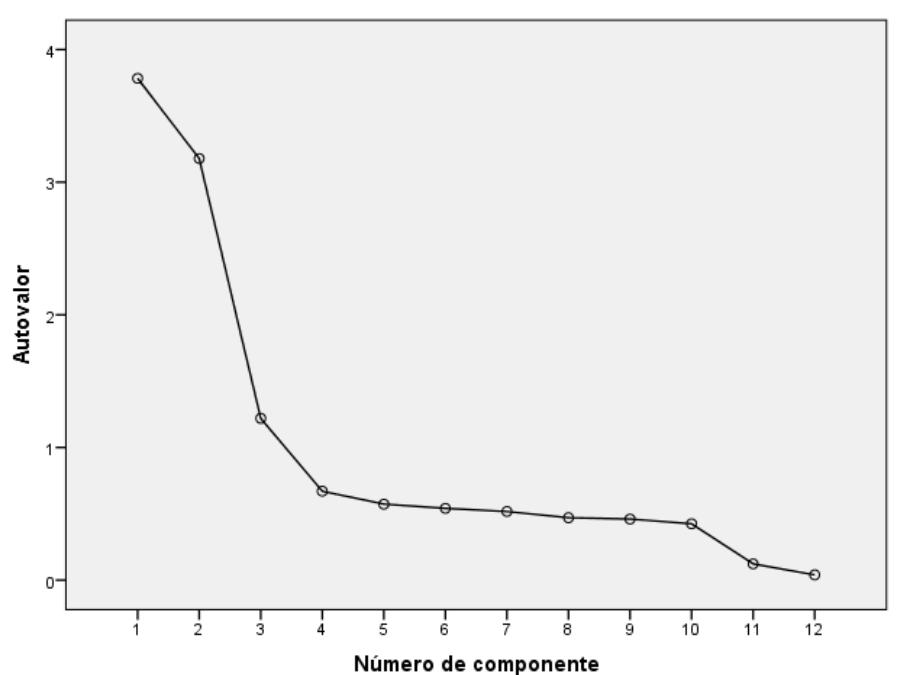


Tabela 4 - Matriz fatorial rotacionada pelo método Varimax e comunalidades referentes aos Déficits de Equipamentos das escolas (Modelo Final).

\begin{tabular}{lrrrr}
\hline \multicolumn{1}{c}{ Variáveis } & \multicolumn{3}{c}{ Componentes } & Comunalidade \\
\cline { 2 - 3 } & \multicolumn{1}{c}{ Connnn} & \multicolumn{1}{c}{3} & & \\
\hline Déficit_Equip_Televisores & 0,958 & 0,029 & $-0,027$ & \\
Déficit_Equip_AparelhosdeDVD & 0,965 & 0,034 & $-0,061$ & 0,936 \\
Déficit_Equip_AparelhosdeCDerádio & 0,939 & 0,076 & 0,047 & 0,890 \\
Déficit_Equip_Circuladoresdear & 0,778 & 0,023 & 0,006 & 0,605 \\
Déficit_Equip_Computadoresparaadministraçãodocentes & $-0,029$ & 0,351 & 0,701 & 0,616 \\
Déficit_Equip_Bebedouroselétricos & 0,026 & 0,684 & 0,194 & 0,506 \\
Déficit_Equip_Freezers & $-0,059$ & 0,726 & 0,114 & 0,544 \\
Déficit_Equip_Geladeiras & 0,121 & 0,661 & 0,310 & 0,547 \\
Déficit_Equip_Fogãoõesindustrialais & 0,077 & 0,809 & 0,013 & 0,661 \\
Déficit_Equip_Liquidificadoresindustrialais & 0,031 & 0,782 & 0,084 & 0,619 \\
Déficit_Equip_Guilhotinasdepapel & $-0,096$ & $-0,041$ & 0,817 & 0,678 \\
Déficit_Equip_Aparelhosdetelefone & 0,129 & 0,414 & 0,687 & 0,659 \\
\hline
\end{tabular}

Tabela 5 - Matriz fatorial rotacionada dos dois subconjuntos utilizados para validação do modelo fatorial referente aos Déficits de Instalações Físicas das escolas (Modelo Final).

\begin{tabular}{lrrrrrc}
\hline \multirow{2}{*}{ Variáveis } & \multicolumn{3}{c}{ Subconjunto 1 } & \multicolumn{3}{c}{ Subconjunto 2 } \\
\cline { 2 - 6 } & 1 & 2 & 3 & 1 & \multicolumn{1}{c}{ 1 } & 3 \\
\hline Déficit_Equip_Televisores & 0,958 & 0,029 & $-0,031$ & 0,958 & 0,029 & $-0,023$ \\
Déficit_Equip_AparelhosdeDVD & 0,965 & 0,037 & $-0,062$ & 0,965 & 0,031 & $-0,060$ \\
Déficit_Equip_AparelhosdeCDerádio & 0,939 & 0,078 & 0,042 & 0,940 & 0,074 & 0,052 \\
Déficit_Equip_Circuladoresdear & 0,767 & 0,031 & 0,008 & 0,788 & 0,015 & 0,005 \\
Déficit_Equip_Computadoresparaadministraçãodocentes & $-0,033$ & 0,346 & 0,704 & $-0,026$ & 0,356 & 0,699 \\
Déficit_Equip_Bebedouroselétricos & 0,036 & 0,686 & 0,189 & 0,016 & 0,681 & 0,199 \\
Déficit_Equip_Freezers & $-0,052$ & 0,728 & 0,119 & $-0,065$ & 0,724 & 0,110 \\
Déficit_Equip_Geladeiras & 0,118 & 0,667 & 0,301 & 0,124 & 0,654 & 0,318 \\
Déficit_Equip_Fogãoõesindustrialais & 0,077 & 0,808 & 0,008 & 0,078 & 0,811 & 0,018 \\
Déficit_Equip_Liquidificadoresindustrialais & 0,031 & 0,787 & 0,085 & 0,031 & 0,777 & 0,082 \\
Déficit_Equip_Guilhotinasdepapel & $-0,094$ & $-0,042$ & 0,817 & $-0,097$ & $-0,040$ & 0,817 \\
Déficit_Equip_Aparelhosdetelefone & 0,122 & 0,414 & 0,686 & 0,135 & 0,414 & 0,687 \\
\hline
\end{tabular}

